Prepared in cooperation with the Chester County Water Resources Authority

\title{
A Benthic-Macroinvertebrate Index of Biotic Integrity and Assessment of Conditions in Selected Streams in Chester County, Pennsylvania, 1998-2009
}

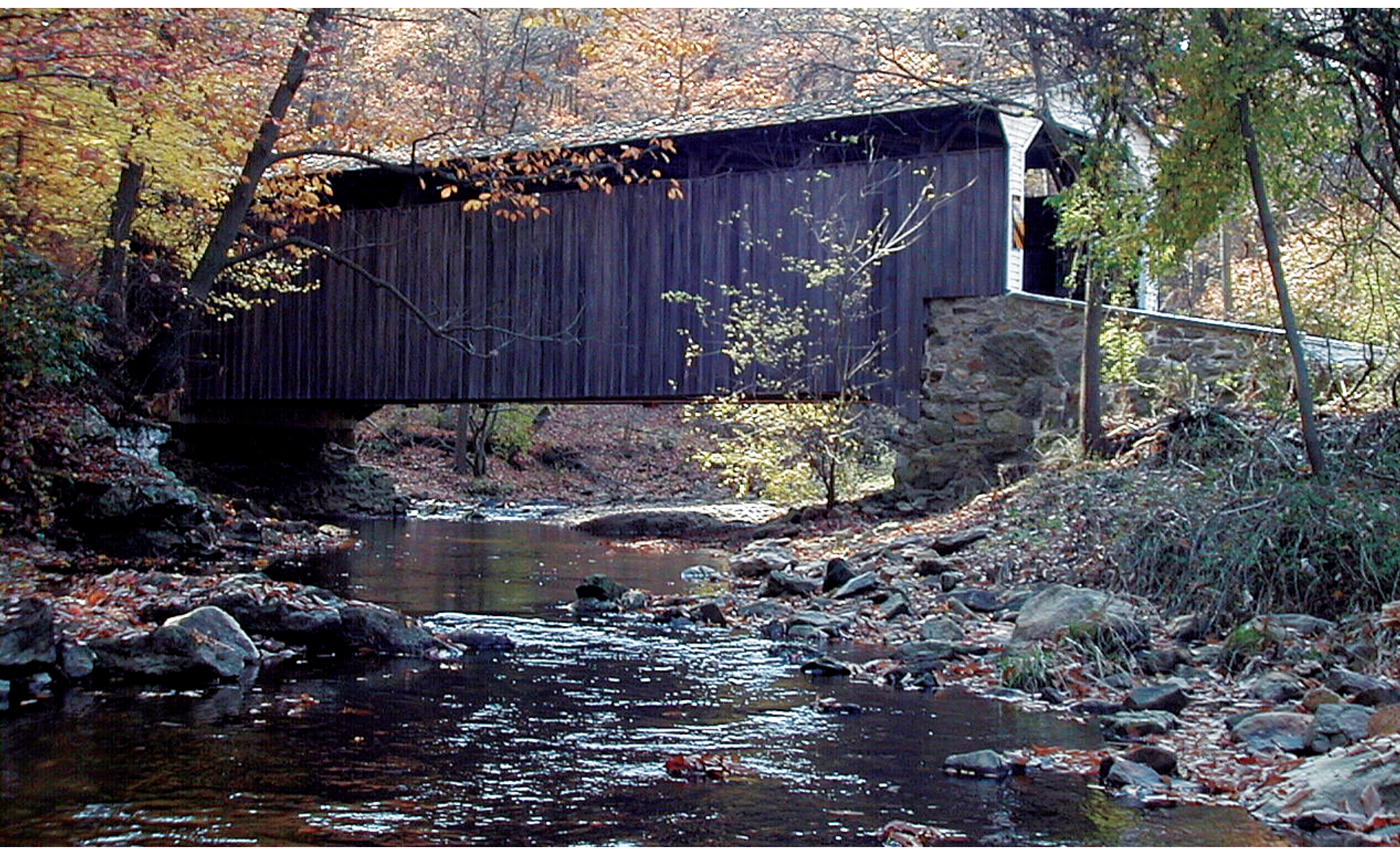

Scientific Investigations Report 2012-5116

U.S. Department of the Interior U.S. Geological Survey 
Cover. Photo showing Little Elk Creek at Elk Mills, Pa. 


\section{A Benthic-Macroinvertebrate Index of Biotic Integrity and Assessment of Conditions in Selected Streams in Chester County, Pennsylvania, 1998-2009}

By Andrew G. Reif

Prepared in cooperation with the Chester County Water Resources Authority

Scientific Investigations Report 2012-5116 


\title{
U.S. Department of the Interior \\ KEN SALAZAR, Secretary \\ U.S. Geological Survey \\ Marcia K. McNutt, Director
}

\author{
U.S. Geological Survey, Reston, Virginia: 2012
}

For more information on the USGS - the Federal source for science about the Earth, its natural and living resources, natural hazards, and the environment, visit http://www.usgs.gov or call 1-888-ASK-USGS.

For an overview of USGS information products, including maps, imagery, and publications, visit http://www.usgs.gov/pubprod

To order this and other USGS information products, visit http://store.usgs.gov

Any use of trade, product, or firm names is for descriptive purposes only and does not imply endorsement by the U.S. Government.

Although this report is in the public domain, permission must be secured from the individual copyright owners to reproduce any copyrighted materials contained within this report.

Suggested citation:

Reif, A.G., 2012, A benthic-macroinvertebrate index of biotic integrity and assessment of conditions in selected streams in Chester County, Pennsylvania, 1998-2009: U.S. Geological Survey Scientific Investigations Report 2012-5116, $41 \mathrm{p}$. 


\section{Contents}

Abstract

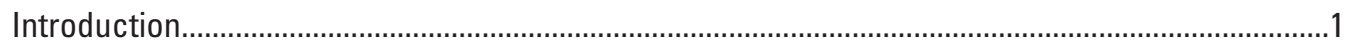

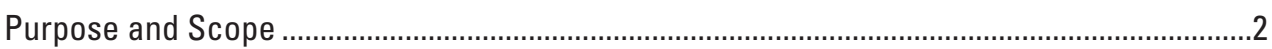

Description of Network.................................................................................................

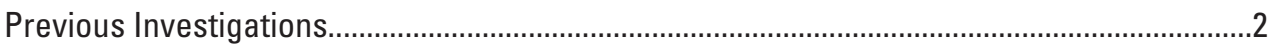

Description of Study Area ...................................................................................................

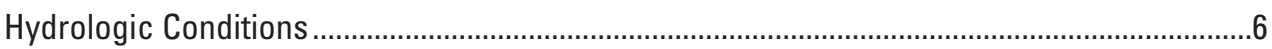

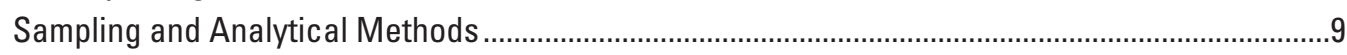

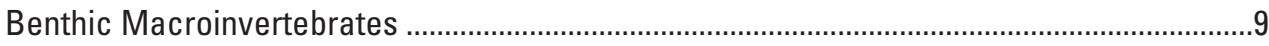

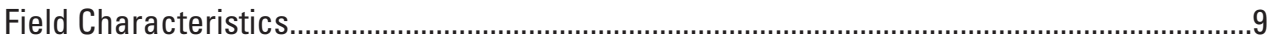

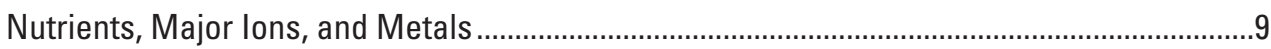

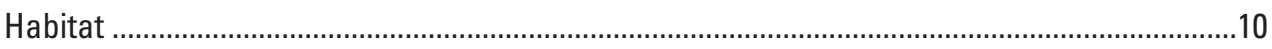

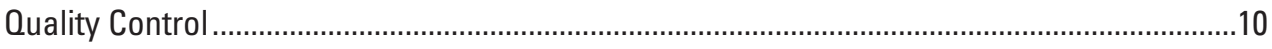

Chester County Index of Biotic Integrity .........................................................................11

Chester County Index of Biotic Integrity Metrics ............................................................11

Reference Condition........................................................................................................12

Chester County Index of Biotic Integrity Calculations.......................................................12

Assessment of Stream Conditions in Chester County, 1998-2009 .................................................15

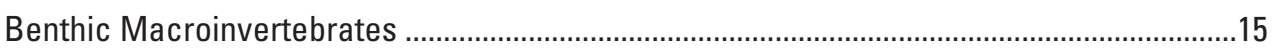

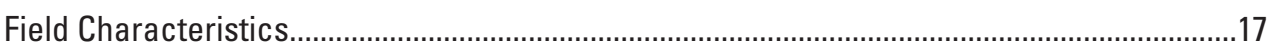

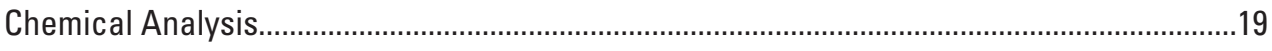

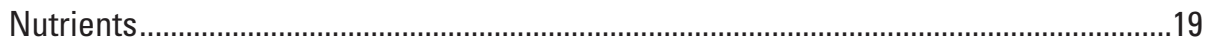

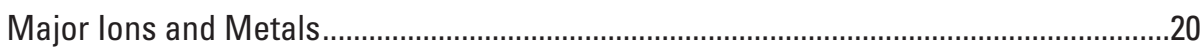

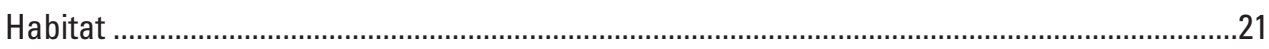

Factors Affecting Chester County Index of Biotic Integrity Scores for

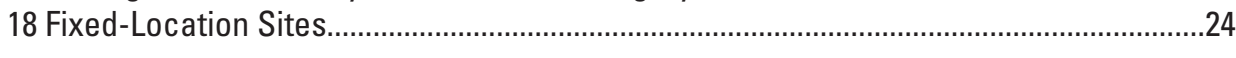

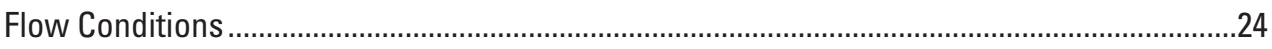

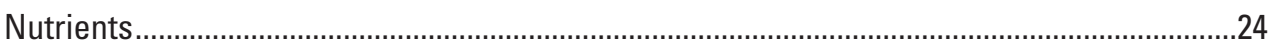

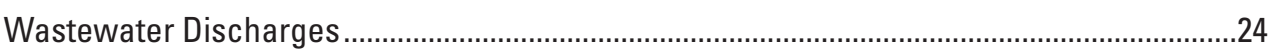

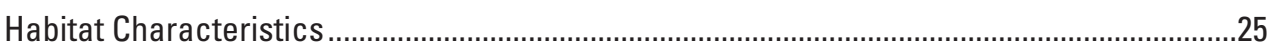

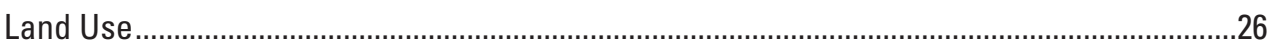

Evaluation of Chester County Index of Biotic Integrity Scores for Selected

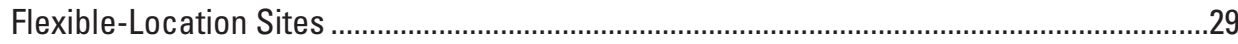

Trends in Chester County Index of Biotic Integrity Scores and Selected Chemical

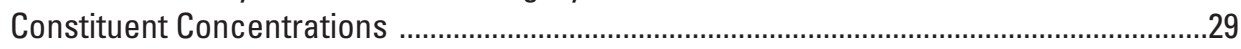

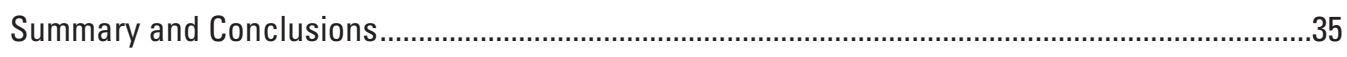

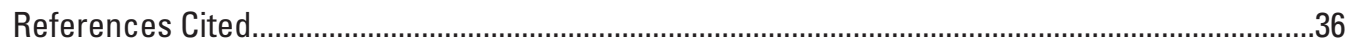

Appendix 1. Organisms with pollution tolerance values and references used in the Chester County Index of Biotic Integrity calculations...................... separate file

Appendix 2. Chester County Index of Biotic Integrity scores, other index scores, and taxa counts for all samples collected as part of the Stream Conditions of Chester County Biological Monitoring Network, Pennsylvania, 1998-2009 
Appendix 3. Constituent concentrations in, and field characteristics of, streamwater samples collected as part of the Stream Conditions of Chester County Biological

Monitoring Network, Chester County, Pennsylvania, 1998-2009. separate file

Appendix 4. Total habitat assessment score and scores of individual habitat characteristics for all sites sampled as part of the Stream Conditions of Chester County Biological Monitoring Network, Chester County, Pennsylvania, 1998-2009. separate file

\section{Figures}

1. Map showing locations of 18 fixed-location sampling sites and major drainage basin divides in Chester County, Pennsylvania .

2. Map showing locations of 84 flexible-location sampling sites and major drainage basin divides in Chester County, Pennsylvania .

3. Map showing land use in 2005 and location of 18 fixed-location sites in the Stream Conditions of Chester County Biological Monitoring Network, Chester County, Pennsylvania, 1998-2009.

4. Map showing sites categorized by range of mean Chester County Index of Biotic Integrity (CC-IBI) score, and generalized land use at 18 fixed-location sites, in the Stream Conditions of Chester County Biological Monitoring Network, Chester County, Pennsylvania, 1998-2009.

5. Graph showing percentage of 213 samples collected from 18 fixed-location sites in the Stream Conditions of Chester County Biological Monitoring Network, Chester County, Pennsylvania, 1998-2009, by Chester County Index of Biotic Integrity score category.

6. Graph showing percentage of 107 samples collected at flexible-location sites in the Stream Conditions of Chester County Biological Monitoring Network, Chester County, Pennsylvania. 1998-2009, by Chester County Index of Biotic Integrity score category.

7. Graph showing relation of percentage of urban land use in the subbasin to mean specific conductance for samples collected at 18 fixed-location sites in the Stream Conditions of Chester County Biological Monitoring Network, Chester County, Pennsylvania, 1998-2009

8. Graph showing relation of percentage of agricultural land use in the subbasin to mean dissolved nitrate concentration for samples collected at 18 fixed-location sites in the Stream Conditions of Chester County Biological Monitoring Network, Chester County, Pennsylvania, 1998-2009...

9. Graph showing mean dissolved orthophosphate concentrations in samples collected at 18 fixed-location sites in the Stream Conditions of Chester County Biological Monitoring Network, Chester County, Pennsylvania, 1998-2009

10. Graph showing relation of percentage of urban land use in the subbasins to mean dissolved chloride concentrations for samples collected at 18 fixed-location sites in the Stream Conditions of Chester County Biological Monitoring Network, Chester County, Pennsylvania, 1998-2009...... 
11. Graph showing relation of mean Chester County Index of Biotic Integrity score to mean dissolved chloride concentrations for samples collected at 18 fixed-location sites in the Stream Conditions of Chester County Biological Monitoring Network, Chester County, Pennsylvania, 1998-2009...

12. Graph showing percentage of sites in 4 categories of 10 habitat characteristics evaluated during collection of 320 benthic-macroinvertebrate samples from sites in the Stream Conditions of Chester County Biological Monitoring Network, Chester County, Pennsylvania, 1998-2009

13. Graph showing relation of mean Chester County Index of Biotic Integrity scores to mean dissolved orthophosphate concentration for samples collected at 18 fixed-location sites in the Stream Conditions of Chester County Biological Monitoring Network, Chester County, Pennsylvania, 1998-2009.

14. Graph showing Chester County Index of Biotic Integrity scores and dissolved orthophosphate concentrations for West Branch Red Clay Creek near Kennett Square, Pennsylvania, site 55, 01479700, 1998-2009.

15. Graph showing mean dissolved boron concentrations for 18 fixed-location sites in the Stream Conditions of Chester County Biological Monitoring Network, Chester County, Pennsylvania, 1998-2009.

16. Graph showing relation of mean Chester County Index of Biotic Integrity scores to mean total habitat scores for samples collected at 18 fixed-location sites in the Stream Conditions of Chester County Biological Monitoring Network, Chester County, Pennsylvania, 1998-2009.

17. Graph showing relation of mean Chester County Index of Biotic Integrity scores to mean embeddedness, mean sediment deposition, mean riparian width, and mean vegetative protection scores for samples collected at 18 fixed-location sites in the Stream Conditions of Chester County Biological Monitoring Network, Chester County, Pennsylvania, 1998-2009.

18. Graph showing relation of mean Chester County Index of Biotic Integrity scores to percentage of land use for samples from 18 fixed-location sites in the Stream Conditions of Chester County Biological Monitoring Network, Chester County, Pennsylvania, 1998-2009.

19. Graphs showing Chester County Index of Biotic Integrity scores for fixed-location sites in the Schuylkill River Basin, Pennsylvania, 1998-2009: $A$, site 10, 01472080, Pigeon Creek at Slonaker, Pa.; $B$, site 15, 01472157, French Creek near Phoenixville, Pa.; $C$, site 5, 01472190, Pickering Creek near Phoenixville, $\mathrm{Pa}$.; and $D$, site 52, 01473169, Valley Creek at PA Turnpike Bridge near Valley Forge, Pa

20. Graphs showing Chester County Index of Biotic Integrity scores for fixed-location sites in the Delaware River Basin, Pennsylvania, 1998-2009: $A$, site 53, 01475850, Crum Creek near Newtown Square, Pa.; B, site 81, 01476450, Ridley Creek at Rt. 3 near Willistown, Pa., 2001-2009; and C, site 24, 01476835, East Branch Chester Creek at Westtown, Pa., 1998-2009.

21. Graphs showing Chester County Index of Biotic Integrity scores for fixed-location sites in the Red Clay and White Clay Creek Basins: $A$, site 28, 01478120, East Branch White Clay Creek at Avondale, Pa.; $B$, site 58, 01478230, Middle Branch White Clay Creek near Avondale, Pa.; C, site 55, 01479700, West Branch Red Clay Creek near Kennett Square, $P a$.; and D, site 26, 01479800, East Branch Red Clay Creek near Five Points, Pa., 1998-2009 
22. Graphs showing Chester County Index of Biotic Integrity scores for fixed-location sites in the Brandywine River Basin, 1998-2009: $A$, site 57, 01480300, West Branch Brandywine Creek near Honey Brook, Pa.; $B$, site 56, 01480617, West Branch Brandywine Creek at Modena, Pa.; $C$, site 46, 01480629, Buck Run at Doe Run, Pa.; $D$, site 42, 01480653, East Branch Brandywine Creek at Glenmoore, Pa.;

and $E$, site 54, 01480870, East Branch Brandywine Creek below Downingtown, Pa.......34

23. Graphs showing Chester County Index of Biotic Integrity scores for fixed-location sites in the Susquehanna River and Chesapeake Bay Basins, 1998-2009: $A$, site 59, 01494953, Big Elk Creek at Maple Grove, Pa.; and B, site 60, 01578347, East Branch Octoraro Creek near Steelville, $\mathrm{Pa}$

\section{Tables}

1. Description of, and number of samples collected from, 18 fixed-location sites in the Stream Conditions of Chester County Biological Monitoring Network, Chester County, Pennsylvania, 1998-2009.

2. Description of, and number of samples collected from, 84 flexible-location sites in the Stream Conditions of Chester County Biological Monitoring Network, Chester County, Pennsylvania, 1998-2009.

3. Description of six continuous-record streamgaging stations that are collocated with fixed-location sites in the Stream Conditions of Chester County Biological Monitoring Network

4. Five-year flood peak and peak discharges measured, September 1 to November 30, at six U.S. Geological Survey continuous-record streamgaging stations in Chester County, Pennsylvania, from 1998-2009.

5. Mean daily discharges, September 1 to November 30, and 90-percent flow duration at six U.S. Geological Survey continuous-record streamgaging stations in Chester County, Pennsylvania, from 1998-2009.

6. Taxonomic groups and references used to identify them in benthicmacroinvertebrate samples

7. Constituents analyzed for in filtered water samples collected from selected streams in Chester County, Pennsylvania, 1998-2009, with laboratory methods, and reporting levels.

8. Summary of constituents in blank samples collected at selected sites in the Stream Conditions of Chester County Biological Monitoring Network, 1998-2009

9. Metric standardization values for the six metrics used to calculate the Chester County Index of Biotic Integrity value

10. Example of standardization and Chester County Index of Biotic Integrity scoring calculation for the sample collected on October 18, 2004, from site 1 (01472170) Pickering Creek near Eagle, Pennsylvania.

11. Statistical summary of Chester County Index of Biotic Integrity scores from 18 fixed-location sites in the Stream Conditions of Chester County Biological Monitoring Network, Chester County, Pennsylvania, 1998-2009.

12. Summary of mean values for stream discharge, field characteristics, and constituent concentrations in stream-water samples collected from 18 fixed-location sites in the Stream Conditions of Chester County Biological Monitoring Network, Chester County, Pennsylvania, 1998-2009. 
13. Summary of mean habitat and stream-characteristics scores for 18 fixed-location sites in the Stream Conditions of Chester County Biological Monitoring Network, Chester County, Pennsylvania, 1998-2009.

14. Percentages of sites, by habitat category and habitat characteristic, evaluated during collection of 320 biological samples at sites in the Stream Conditions of Chester County Biological Monitoring Network, Chester County, Pennsylvania, 1998-2009.

15. Summary of land use in the subbasin of 18 fixed-location sites in the Stream Conditions of Chester County Biological Monitoring Network, Chester County, Pennsylvania, 1998-2009. . .27

16. Summary of land use in the subbasin of selected flexible-location sites in the Stream Conditions of Chester County Biological Monitoring Network, Chester County, Pennsylvania, 1998-2009.

17. Physical characteristics, constituent concentrations, and selected index scores for selected flexible-location sites in the Stream Conditions of Chester County Biological Monitoring Network, Chester County, Pennsylvania, 1998-2009...

18. Results of the Mann Kendall test for trends in Chester County Index of Biotic Integrity scores, nitrate concentrations, orthophosphate concentrations, and chloride concentrations for 18 fixed-location sites in the Stream Conditions of Chester County Biological Monitoring Network, Chester County, Pennsylvania, 1998-2009. 


\section{Conversion Factors}

SI to Inch/Pound

\begin{tabular}{|c|c|c|}
\hline Multiply & By & To obtain \\
\hline \multicolumn{3}{|c|}{ Length } \\
\hline centimeter $(\mathrm{cm})$ & 0.3937 & inch (in) \\
\hline millimeter $(\mathrm{mm})$ & 0.03937 & inch (in) \\
\hline meter $(\mathrm{m})$ & 3.281 & foot $(\mathrm{ft})$ \\
\hline kilometer (km) & 0.6214 & mile (mi) \\
\hline meter $(\mathrm{m})$ & 1.094 & yard (yd) \\
\hline \multicolumn{3}{|c|}{ Area } \\
\hline square meter $\left(\mathrm{m}^{2}\right)$ & 0.0002471 & acre \\
\hline hectare (ha) & 0.003861 & square mile $\left(\mathrm{mi}^{2}\right)$ \\
\hline square kilometer $\left(\mathrm{km}^{2}\right)$ & 0.3861 & square mile $\left(\mathrm{mi}^{2}\right)$ \\
\hline \multicolumn{3}{|c|}{ Volume } \\
\hline liter $(\mathrm{L})$ & 33.82 & ounce, fluid (fl. oz) \\
\hline liter (L) & 2.113 & pint $(p t)$ \\
\hline liter $(\mathrm{L})$ & 1.057 & quart (qt) \\
\hline liter $(\mathrm{L})$ & 0.2642 & gallon (gal) \\
\hline \multicolumn{3}{|c|}{ Flow rate } \\
\hline cubic meter per second $\left(\mathrm{m}^{3} / \mathrm{s}\right)$ & 35.31 & cubic foot per second $\left(\mathrm{ft}^{3} / \mathrm{s}\right)$ \\
\hline \multicolumn{3}{|c|}{ Mass } \\
\hline $\operatorname{gram}(\mathrm{g})$ & 0.03527 & ounce, avoirdupois (oz) \\
\hline
\end{tabular}

Temperature in degrees Celsius $\left({ }^{\circ} \mathrm{C}\right)$ may be converted to degrees Fahrenheit $\left({ }^{\circ} \mathrm{F}\right)$ as follows:

${ }^{\circ} \mathrm{F}=\left(1.8 x^{\circ} \mathrm{C}\right)+32$

Temperature in degrees Fahrenheit $\left({ }^{\circ} \mathrm{F}\right)$ may be converted to degrees Celsius $\left({ }^{\circ} \mathrm{C}\right)$ as follows:

${ }^{\circ} \mathrm{C}=\left({ }^{\circ} \mathrm{F}-32\right) / 1.8$

Vertical coordinate information is referenced to the North American Vertical Datum of 1988 (NAVD 88)

Elevation, as used in this report, refers to distance above the vertical datum.

Concentrations of chemical constituents in water are given either in milligrams per liter (mg/L) or micrograms per liter $(\mu \mathrm{g} / \mathrm{L})$. 


\title{
A Benthic-Macroinvertebrate Index of Biotic Integrity and Assessment of Conditions for Selected Streams in Chester County Pennsylvania, 1998-2009
}

\author{
By Andrew G. Reif
}

\section{Abstract}

The Stream Conditions of Chester County Biological Monitoring Network (Network) was established by the U.S. Geological Survey and the Chester County Water Resources Authority in 1969. Chester County encompasses 760 square miles in southeastern Pennsylvania and has a rapidly expanding population. Land-use change has occurred in response to this continual growth, as open space, agricultural lands, and wooded lands have been converted to residential and commercial lands. In 1998, the Network was modified to include 18 fixed-location sites and 9 flexible-location sites. Sites were sampled annually in the fall (October-November) during baseflow conditions for water chemistry, instream habitat, and benthic macroinvertebrates. A new set of 9 flexible-location sites was selected each year. From 1998 to 2009, 213 samples were collected from the 18 fixed-location sites and 107 samples were collected from the 84 flexible-location sites. Eighteen flexible-location sites were sampled more than once over the 12-year period; 66 sites were sampled only once.

Benthic-macroinvertebrate data from samples collected during 1998-2009 were used to establish the Chester County Index of Biotic Integrity (CC-IBI). The CC-IBI was based on the methods and metrics outlined in the Pennsylvania Department of Environmental Protection's "A Benthic Index of Biotic Integrity for Wadeable Freestone Streams in Pennsylvania." The resulting CC-IBI consists of scores for benthicmacroinvertebrate samples collected from sites in the Network that related to reference conditions in Chester County.

Mean CC-IBI scores for 18 fixed-location sites ranged from 37.21 to 88.92 . Thirty-nine percent of the 213 samples collected at the 18 fixed-location sites had a CC-IBI score less than $50 ; 33$ percent, 50 to $70 ; 28$ percent, greater than 70 . CC-IBI scores from the 107 flexible-location samples ranged from 23.48 to 99.96 . Twenty-five percent of the 107 samples collected at the flexible-location sites had a CC-IBI score less than 50; 33 percent, 50 to 70 ; and 42 percent, greater than 70 .

Factors that were found to affect CC-IBI scores are nutrient concentrations, habitat conditions, and percent of wooded and urban land use. A positive relation was determined between mean CC-IBI scores and mean total habitat scores for the 18 fixed-location sites. CC-IBI scores were most strongly affected by stream bank vegetative protection, embeddedness, riparian zone width, and sediment deposition. The highest CC-IBI scores were associated with sites that had greater than 28 percent wooded-wetland-water land use, less than 5 percent urban land use, and no municipal wastewater discharges within 10 miles upstream from the sampling site. The lowest CC-IBI scores were associated with sites where urban land use was greater than 15 percent or a municipal wastewater discharge was within 10 miles upstream from the sampling reach.

The Mann Kendall test for trends was used to determine trends in CC-IBI scores and concentrations of nitrate, orthophosphate, and chloride for the 18 fixed-location sites. A positive trend in CC-IBI was determined for six sites, and a negative trend was determined for one site. Positive trends in nitrate concentrations were determined for 4 of the 18 fixedlocation sites, and a negative trend in orthophosphate concentrations was determined for 1 of the 18 fixed-location sites. Positive trends in chloride concentrations were determined for 16 of the 18 fixed-location sites.

\section{Introduction}

The Stream Conditions of Chester County Biological Monitoring Network (Network) was established by the U.S. Geological Survey (USGS) and the Chester County Water Resources Authority (CCWRA) in 1969 with the goal of assessing the quality of Chester County streams and to gain an understanding of stream changes in response to urbanization (Lium, 1977). Stream samples collected from all sites were analyzed for stream-water chemistry (dissolved nutrients, major ions, and metals) and benthic macroinvertebrates and evaluated for instream habitat (1998-2009). Benthic macroinvertebrates are aquatic organisms that live on the stream bottom. Evaluation of benthic-macroinvertebrate communities is an useful tool for evaluating stream quality at a specific site because the habitat preference and low mobility of benthic macroinvertebrates cause them to be directly affected by water 
quality and physical conditions. Therefore, benthic-macroinvertebrate communities, which are good indicators of overall stream quality, are used to assess the long-term cumulative effects of various chemical and physical stressors. A high quality stream supports and maintains a diverse assemblage of benthic macroinvertebrates, including numerous taxa of pollution intolerant organisms. Additionally, chemical and habitat data from a site can be used to associate specific stressors with the presence or absence of benthic macroinvertebrates.

Benthic-macroinvertebrate data from the Network were evaluated using the Brillouin's diversity index (1970-1980; Moore, 1987) and a multi-metric evaluation (1981-1997; Reif, 2002). Data from 1998 to 2009 were used to establish the Chester County Index of Biotic Integrity (CC-IBI). An index of biotic integrity (IBI) rates community-level biological attributes (structure, composition, pollution tolerance, diversity) in comparison to a reference or minimally disturbed condition. The Pennsylvania Department of Environmental Protection (PaDEP) published "A Benthic Index of Biotic Integrity for Wadeable Freestone Streams in Pennsylvania" (Pa-IBI) in 2007 (Chalfant, 2007). The CC-IBI was established by adapting the methods and metrics outlined in the Pa-IBI to the collection methods used in the Network and was calibrated using data collected during 1998-2009 from the Network. The resulting CC-IBI has site-specific scores that were based on benthic-macroinvertebrate samples collected from the Network during 1998-2009 and related to reference conditions found in Chester County.

The assessment of conditions in selected streams in Chester County, Pennsylvania, was conducted by the USGS in cooperation with the CCWRA. The Chester County study area includes small parts of Berks, Delaware, Lancaster, and Montgomery Counties that drained to the sampling sites. The results of this study can be used by Chester County government agencies to identify streams with stressed or impaired benthic macroinvertebrate communities and to assess the effects of environmental and land-use practices on the waters of Chester County.

\section{Purpose and Scope}

This report documents the sampling methods and summarizes chemical, biological, and habitat data obtained from samples collected from the Network during 1998-2009. The establishment and calibration of the CC-IBI are detailed, and results are presented and discussed. CC-IBI scores are given for all 320 samples collected at 102 sites during 1998-2009. An evaluation of the relation between chemical and habitat data and benthic-macroinvertebrate data is presented.

\section{Description of Network}

The Network was established in the fall of 1969, and reconnaissance sampling was conducted to determine the general conditions of streams and land-use patterns in Chester
County. In 1970, the results of the reconnaissance sampling were used to select 50 sites on 13 stream subbasins for a chemical and biological stream-quality network. The sites were selected on the basis of equal cumulative square miles of drainage area within each subbasin (Lium, 1977). The sites were distant from known point discharges so that the overall water quality of a subbasin could be evaluated. Twelve sites were added, and 9 sites were removed from the Network from 1972 to 1981 . Forty-three sites were sampled annually between 1982 and 1997.

In 1998, changes were made to the number and location of sampling sites in the Network to reduce redundancy and cost. A modified Network consisting of 18 fixed-location sites (table 1) and 9 flexible-location sites was established.

The 18 fixed-location sites are in the major drainage basins throughout Chester County. Most sites were located near the bottom of the subbasin or near the county border (fig. 1). These 18 fixed-location sites were sampled annually in the fall (October-November) for water chemistry, instream habitat, and benthic macroinvertebrates. The 18 fixed-location sites included 5 sites from the original Network and 13 new sites. Six of the 18 fixed-location sites were located at USGS continuous-record streamgaging stations so that flow data could be compared to the biological data.

Flexible-site locations were selected annually in consultation with the CCWRA and were used to expand the geographic coverage of sampled streams and for detailed reconnaissance sampling in individual subbasins. Nine flexible-location sites were selected each year. Eighteen flexible-location sites were sampled more than once over the 12-year period; 66 sites were sampled only once, and a total of 84 different sites were sampled during 1998-2009 (fig. 2; table 2, at end of report). The current Network structure allows for the collection of data for the determination of long-term trends (18 fixed-location sites) and for short-term site evaluations ( 9 flexible-location sites).

\section{Previous Investigations}

The physical, chemical, and biological data collected from the Network have been reported in four USGS data reports. Complete analytical and biological results are given by Moore (1989) for 1969 to 1980, Reif (1999) for 1981 to 1994, Reif (2000) for 1995 to 1997, and Reif (2003) for 1998 to 2000. Data collected from 2001 to 2009 were published in the USGS annual water-data reports for Pennsylvania (U.S. Geological Survey, 2002-2010). The data generated from the Network have been evaluated in numerous USGS reports.

Lium (1977) developed a biotic index that used a 10-point rating scale to assess the environmental conditions at the original 50 Network sites on the basis of data from his 1976 data report (Lium 1976). Lium reported that the streams with the highest ratings were associated with rural or agricultural land use, and the streams with the lowest ratings were associated with industrial land use or were downstream from a wastewater-discharge point. Moore (1987) and Reif (2002) 
Table 1. Description of, and number of samples collected from, 18 fixed-location sites in the Stream Conditions of Chester County Biological Monitoring Network, Chester County, Pennsylvania, 1998-2009.

[USGS, U.S. Geological Survey; $\mathrm{mi}^{2}$, square miles]

\begin{tabular}{|c|c|c|c|c|c|c|c|}
\hline $\begin{array}{c}\text { USGS } \\
\text { station } \\
\text { number }\end{array}$ & $\begin{array}{c}\text { USGS } \\
\text { site } \\
\text { identifier }\end{array}$ & Basin & Stream & $\begin{array}{c}\text { Drainage } \\
\text { area } \\
\left(\mathrm{mi}^{2}\right)\end{array}$ & Latitude & Longitude & $\begin{array}{c}\text { Number } \\
\text { of } \\
\text { samples }\end{array}$ \\
\hline 01472080 & 10 & Schuylkill & Pigeon Creek near Slonaker, Pa. & 12.0 & $40^{\circ} 12^{\prime} 03^{\prime \prime}$ & $75^{\circ} 37^{\prime} 10^{\prime \prime}$ & 12 \\
\hline 01472157 & 15 & Schuylkill & French Creek near Phoenixville, Pa. & 59.1 & $40^{\circ} 09^{\prime} 05^{\prime \prime}$ & $75^{\circ} 36^{\prime} 06^{\prime \prime}$ & 12 \\
\hline 01472190 & 5 & Schuylkill & Pickering Creek near Phoenixville, Pa. & 31.4 & $40^{\circ} 06^{\prime} 33^{\prime \prime}$ & $75^{\circ} 31^{\prime} 42^{\prime \prime}$ & 12 \\
\hline 01473169 & 52 & Schuylkill & Valley Creek at PA Turnpike Br. near Valley Forge, Pa. & 20.8 & $40^{\circ} 04^{\prime} 45^{\prime \prime}$ & $75^{\circ} 27^{\prime} 40^{\prime \prime}$ & 12 \\
\hline 01476450 & 81 & Delaware & Ridley Creek at Rt. 3 near Willistown, Pa. & 13.9 & $39^{\circ} 58^{\prime} 01^{\prime \prime}$ & $75^{\circ} 28^{\prime} 58^{\prime \prime}$ & 9 \\
\hline 01476835 & 24 & Delaware & East Branch Chester Creek at Westtown, Pa. & 10.4 & $39^{\circ} 56^{\prime} 26^{\prime \prime}$ & $75^{\circ} 32^{\prime} 30^{\prime \prime}$ & 12 \\
\hline 01478120 & 28 & Christina & East Branch White Clay Creek at Avondale, Pa. & 11.3 & $39^{\circ} 49^{\prime} 42^{\prime \prime}$ & $75^{\circ} 46^{\prime} 52^{\prime \prime}$ & 12 \\
\hline 01478230 & 58 & Christina & Middle Branch White Clay Creek near Avondale, Pa. & 25.5 & $39^{\circ} 45^{\prime} 02^{\prime \prime}$ & $75^{\circ} 46^{\prime} 19^{\prime \prime}$ & 12 \\
\hline 01480617 & 56 & Christina & West Branch Brandywine Creek at Modena, Pa. & 55.0 & $39^{\circ} 57^{\prime} 42^{\prime \prime}$ & $75^{\circ} 48^{\prime} 06^{\prime \prime}$ & 12 \\
\hline 01480629 & 46 & Christina & Buck Run at Doe Run, Pa. & 22.6 & $39^{\circ} 55^{\prime} 46^{\prime \prime}$ & $75^{\circ} 49^{\prime} 24^{\prime \prime}$ & 12 \\
\hline 01480653 & 42 & Christina & East Branch Brandywine Creek at Glenmoore, Pa. & 16.5 & $40^{\circ} 05^{\prime} 48^{\prime \prime}$ & $75^{\circ} 46^{\prime} 44^{\prime \prime}$ & 12 \\
\hline 01480870 & 54 & Christina & East Branch Brandywine Creek below Downingtown, Pa. & 89.9 & $39^{\circ} 58^{\prime} 07^{\prime \prime}$ & $75^{\circ} 40^{\prime} 25^{\prime \prime}$ & 12 \\
\hline 01494953 & 59 & Chesapeake Bay & Big Elk Creek at Maple Grove, Pa. & 26.6 & $39^{\circ} 45^{\prime} 44^{\prime \prime}$ & $75^{\circ} 55^{\prime} 16^{\prime \prime}$ & 12 \\
\hline 01578347 & 60 & Susquehanna & East Branch Octoraro Creek near Steelville, Pa. & 37.3 & $39^{\circ} 52^{\prime} 58^{\prime \prime}$ & $75^{\circ} 59^{\prime} 31^{\prime \prime}$ & 12 \\
\hline
\end{tabular}

evaluated the physical, chemical, and biological data collected at Network sites from 1969 to 1997 . Moore reported that 44 of the 46 sites sampled between 1969 and 1980 had positive trends and 2 sites had negative trends in benthic-macroinvertebrate diversity. The positive trend was statistically significant above the 90 -percent confidence interval at 27 sites. Reif reported that 10 of the 43 sites sampled during 1981-1997 had positive trends and 4 sites had negative trends in benthicmacroinvertebrate diversity that were significant above the 90-percent confidence interval. The sites with the lowest benthic-macroinvertebrate diversity ratings were in areas with greater than 50 percent agricultural land use, areas with greater than 10 percent impervious cover (streets and other paved surfaces), and areas affected by wastewater discharge. Sloto (1987) evaluated the effects of urbanization on the water resources of eastern Chester County and found that benthicmacroinvertebrate diversity was increasing across all land-use types in areas of growing urbanization and in areas of stable land uses. This increase in diversity was attributed to the flushing of pesticides, such as DDT, from the stream systems over time. Hardy and others (1995) examined land-use changes and concentrations of organochlorine compounds in stream-bottom sediments in relation to trends in diversity indexes of benthic-macroinvertebrate communities and reported a relation between increases in benthic-macroinvertebrate diversity ratings and increases in residential land use. Hardy also reported a relation between low benthic-macroinvertebrate diversity ratings and organochlorine-compound concentrations greater than 45 micrograms per kilogram in stream-bottom sediments. Data from the Network also were used to evaluate water quality in investigations by Vogel and Reif (1993) in the Red Clay Creek subbasin, Senior and others (1994) in the West Valley Creek subbasin, and Cinotto and others (2005) in the Broad Run subbasin.

\section{Description of Study Area}

Chester County encompasses about 760 square miles $\left(\mathrm{mi}^{2}\right)$ and lies in the Piedmont Physiographic Province in southeastern Pennsylvania. The topography is generally characterized by rolling hills and ranges in elevation from about 150 to $1,000 \mathrm{ft}$ above NAVD88 (North American Vertical 


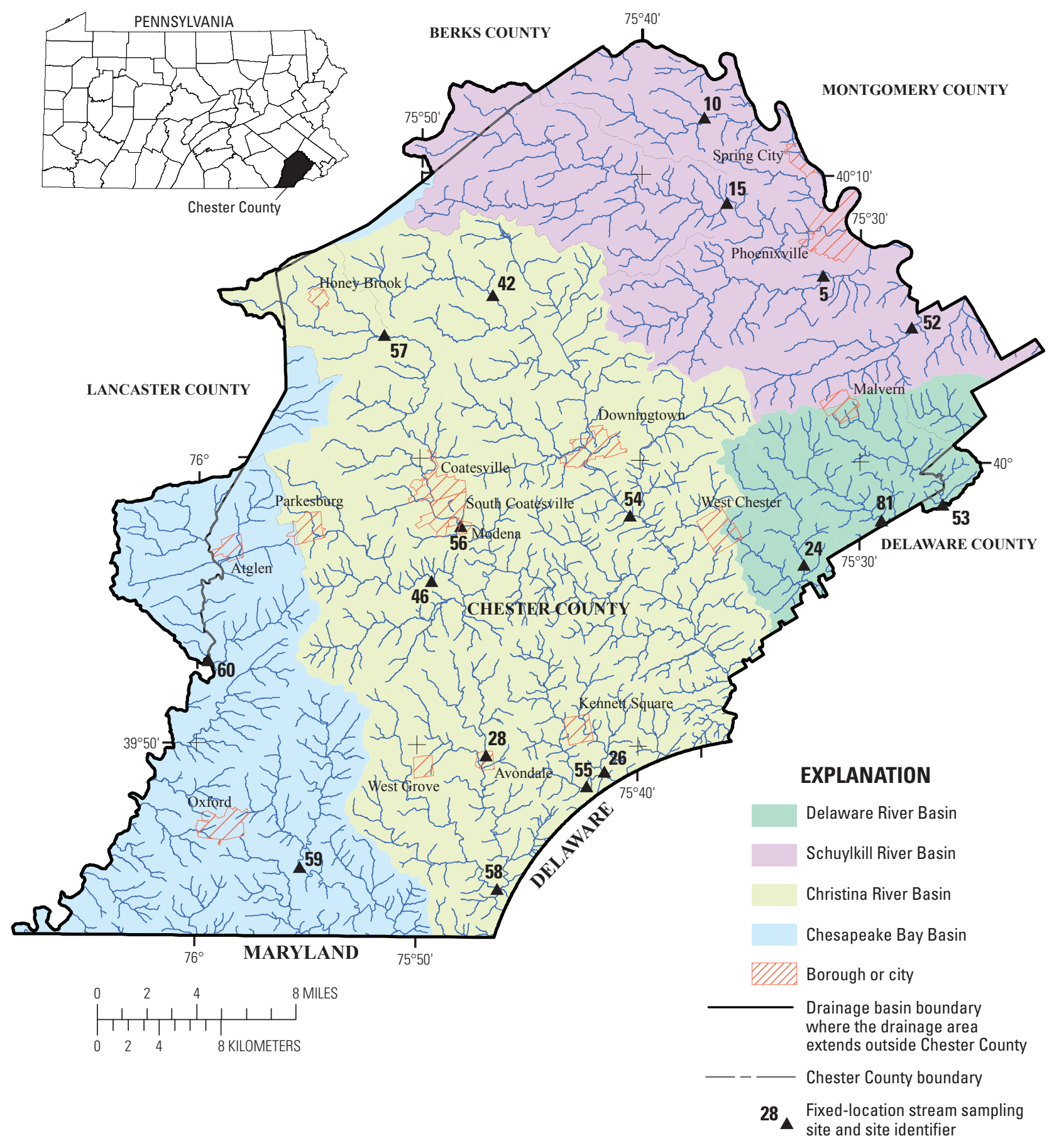

Figure 1. Locations of 18 fixed-location sampling sites and major drainage basin divides in Chester County, Pennsylvania. (Parts of Berks, Delaware, Lancaster, and Montgomery Counties are included in the study area where they contributed to the drainage area at a sampling site.) 


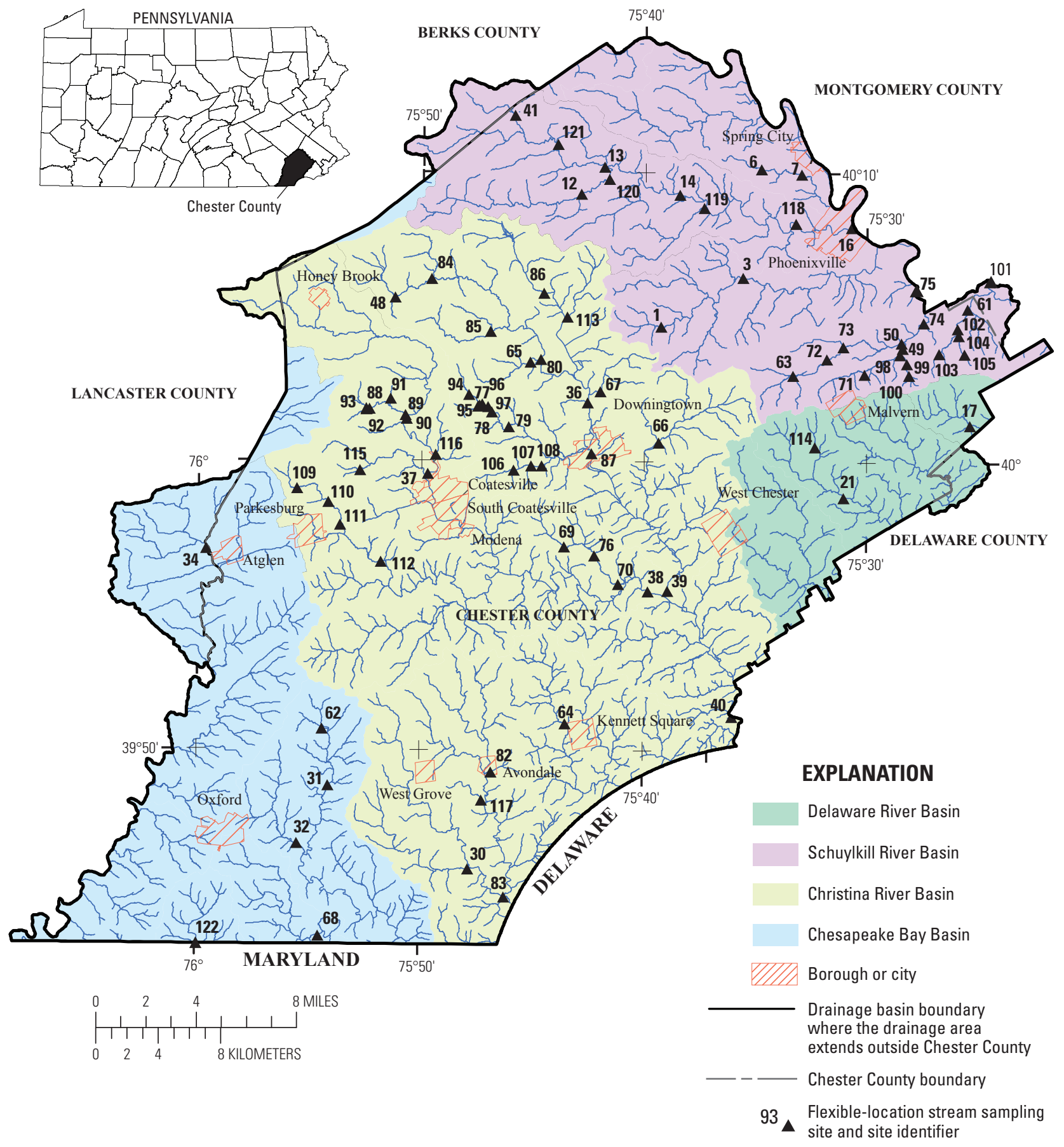

Figure 2. Locations of 84 flexible-location sampling sites and major drainage basin divides in Chester County, Pennsylvania. (Parts of Berks, Delaware, Lancaster, and Montgomery Counties are included in the study area where they contributed to the drainage area at a sampling site.) 
Datum of 1988). Chester County has a humid temperate climate and receives an average total annual precipitation of about 48 inches, which is evenly distributed throughout the year. [The 30-year normal (1971-2000) precipitation for meteorological station West Chester 2NW is 47.89 in. (National Oceanic and Atmospheric Administration, 2005).]

The streams in the Network drain over 95 percent of Chester County. Streams sampled in this study are tributaries to the Schuylkill River, Delaware River, Christina River, Chesapeake Bay, and Susquehanna River. Headwaters of the Octoraro, West Branch Brandywine, and French Creeks are outside Chester County. All other streams originate within Chester County. The largest subbasin is the Brandywine Creek subbasin which drains $290 \mathrm{mi}^{2}$ (38 percent) of the county. The eastern part of the county contains a mix of urban and suburban areas; the southern and western parts of the county contain agricultural and suburban areas (fig. 3). Major crops are hay, corn, vegetables, and mushrooms. Dairy and equestrian farms are common in the area. In 2000, about 39 percent of the land was agricultural; 31 percent wooded-rangeland-water; 17 percent residential; and 13 percent urban or barren, which includes transportation and parking (Delaware Valley Regional Planning Commission, 2004).

Chester County has had rapid population growth over the past 40 years (1972-2011). The county nearly doubled in population from 1960 to 1995 , increasing from 210,600 to 412,000 (Chester County, 1996). Chester County had a 15-percent increase in population from 2000 to 2009. This increased the county's population to 498,900 (U.S. Census Bureau, 2010). Population projections indicate the county will have 557,600 residents by 2020 (Delaware Valley Regional Planning Commission, 2007). In response to this continual growth, open space and farm land have been converted to residential and commercial lands. Population centers in Chester County include the City of Coatesville and the Boroughs of Atglen, Avondale, Downingtown, Honey Brook, Kennett Square, Malvern, Oxford, Parkesburg, Phoenixville, South Coatesville, Spring City, West Chester, and West Grove (fig. 1).

\section{Hydrologic Conditions}

The organisms collected in a benthic-macroinvertebrate sample are dependent on recent hydrologic conditions. Extreme low-flow conditions can lead to variations in concentrations of certain chemical constituents, increased water temperatures, and increased algae growth that may result in reduced dissolved oxygen levels which can negatively affect benthic-macroinvertebrate communities. In contrast, extreme high-flow conditions that occur immediately prior to sampling can cause organisms to be physically removed from the sampling reach, resulting in a temporally altered benthicmacroinvertebrate community. All samples were collected during base-flow conditions and sampling did not occur after high-flow conditions until flow returned to antecedent conditions. Although all samples were collected during base-flow conditions, instream flow varied annually on the basis of the conditions at the time of sampling. Base flow during wet years was higher than base flow during dry years.

Flow statistics from six USGS continuous-record streamgaging stations collected at fixed-location sites in the Network were used to determine which sampling years may have been affected by high or low flows (table 3). High-flow events were determined by comparing the peak discharge recorded at each continuous-record streamgaging station from September 1 to November 30 to the 5-year flood peak for that continuous-record streamgaging station. Rainfall from Hurricane Floyd affected Chester County on September 15, 1999, with widespread flooding. High-flow events greater than the 5 -year peak were recorded at one or more continuous-record streamgaging stations prior to sampling in 1999, 2003, 2004, and 2005 (table 4) (U.S. Geological Survey, 2009). Extreme low-flow conditions (less than the 90-percent flow duration) were observed during sample collection in 2001 (table 5) (U.S. Geological Survey, 2009). The 90-percent flow-duration statistic represents the flow at a continuous-record streamgaging station that has been exceeded 90 percent of the time over the period of record for that streamgaging station.

Table 3. Description of six continuous-record streamgaging stations that are collocated with fixed-location sites in the Stream Conditions of Chester County Biological Monitoring Network.

[USGS, U.S. Geological Survey]

\begin{tabular}{ccllll}
\hline $\begin{array}{c}\text { USGS station } \\
\text { number }\end{array}$ & $\begin{array}{c}\text { USGS site } \\
\text { identifier }\end{array}$ & \multicolumn{1}{c}{ Stream } & Latitude & $\begin{array}{c}\text { Longitude } \\
\text { record }\end{array}$ & $\begin{array}{c}\text { Period of } \\
\text { recen }\end{array}$ \\
\hline 01472157 & 15 & French Creek near Phoenixville, Pa. & $40^{\circ} 09^{\prime} 05^{\prime \prime}$ & $75^{\circ} 36^{\prime} 06^{\prime \prime}$ & $1968-2009$ \\
01473169 & 52 & Valley Creek at PA Turnpike Br. near Valley Forge, Pa. & $40^{\circ} 04^{\prime} 45^{\prime \prime}$ & $75^{\circ} 27^{\prime} 40^{\prime \prime}$ & $1982-2009$ \\
01475850 & 53 & Crum Creek near Newtown Square, Pa. & $39^{\circ} 58^{\prime} 35^{\prime \prime}$ & $75^{\circ} 26^{\prime} 13^{\prime \prime}$ & $1981-2009$ \\
01480300 & 57 & West Branch Brandywine Creek near Honey Brook, Pa. & $40^{\circ} 04^{\prime} 22^{\prime \prime}$ & $75^{\circ} 51^{\prime} 40^{\prime \prime}$ & $1960-2009$ \\
01480617 & 56 & West Branch Brandywine Creek at Modena, Pa. & $39^{\circ} 57^{\prime} 42^{\prime \prime}$ & $75^{\circ} 48^{\prime} 06^{\prime \prime}$ & $1970-2009$ \\
01480870 & 54 & East Branch Brandywine Creek below Downingtown, Pa. & $39^{\circ} 58^{\prime} 07^{\prime \prime}$ & $75^{\circ} 40^{\prime} 25^{\prime \prime}$ & $1972-2009$ \\
\hline
\end{tabular}




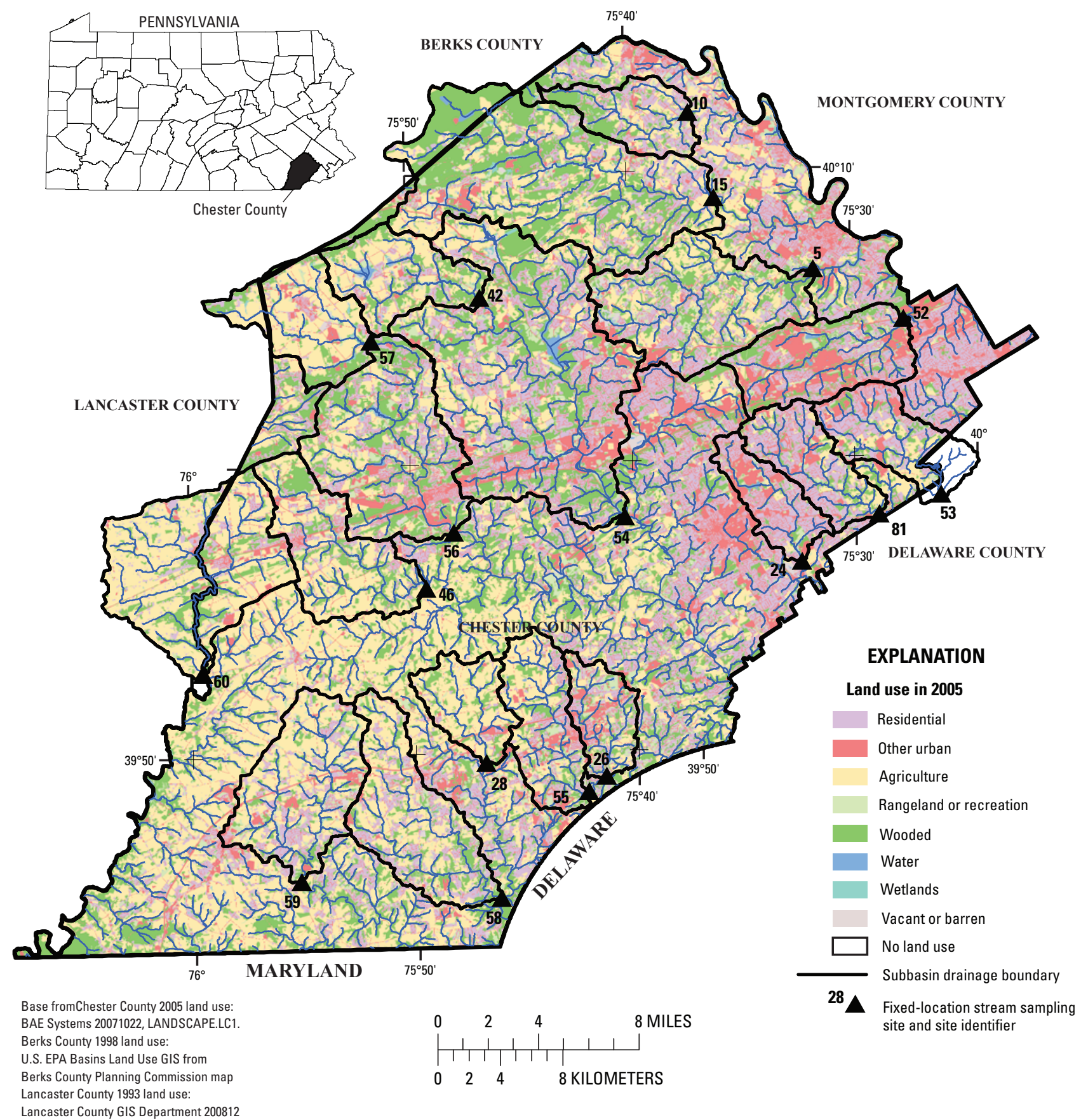

Figure 3. Land use in 2005 and location of 18 fixed-location sites in the Stream Conditions of Chester County Biological Monitoring Network, Chester County, Pennsylvania, 1998-2009. 
Table 4. Five-year flood peak and peak discharges measured, September 1 to November 30, at six U.S. Geological Survey continuous-record streamgaging stations in Chester County, Pennsylvania, from 1998-2009.

[Blue shading indicates flow greater than the 5-year peak flow; USGS, U.S. Geological Survey; $\mathrm{ft}^{3} / \mathrm{s}$, cubic feet per second]

\begin{tabular}{|c|c|c|c|c|c|c|}
\hline \multirow{5}{*}{ Year } & \multicolumn{6}{|c|}{ USGS streamgaging station } \\
\hline & 01472157 & 01473169 & 01475850 & 01480300 & 01480617 & 01480870 \\
\hline & \multicolumn{6}{|c|}{ 5-year flood peak (fts) } \\
\hline & 4,550 & 2,060 & 1,930 & 2,200 & 4,620 & 5,060 \\
\hline & \multicolumn{6}{|c|}{ Peak discharge (September 1-November 30) $\left(\mathrm{ft}^{3} / \mathrm{s}\right)$} \\
\hline 1998 & 189 & 213 & 76 & 255 & 266 & 385 \\
\hline 1999 & 9,370 & 5,970 & 4,190 & 2,950 & 5,260 & 7,160 \\
\hline 2000 & 401 & 860 & 284 & 368 & 539 & 1,330 \\
\hline 2001 & 163 & 348 & 104 & 107 & 405 & 334 \\
\hline 2002 & 523 & 421 & 204 & 215 & 560 & 988 \\
\hline 2003 & 3,460 & 1,720 & 953 & 1,550 & 1,700 & 6,230 \\
\hline 2004 & 3,360 & 2,730 & 3,540 & 1,610 & 1,950 & 5,670 \\
\hline 2005 & 5,590 & 1,030 & 493 & 3,390 & 6,090 & 3,760 \\
\hline 2006 & 1,720 & 733 & 770 & 1,240 & 1,170 & 2,260 \\
\hline 2007 & 655 & 920 & 1,040 & 361 & 854 & 1,490 \\
\hline 2008 & 1,220 & 1,130 & 676 & 300 & 543 & 1,700 \\
\hline 2009 & 1,020 & 852 & 1,540 & 550 & 771 & 1,540 \\
\hline
\end{tabular}

Table 5. Mean daily discharges, September 1 to November 30, and 90-percent flow duration at six U.S. Geological Survey continuous-record streamgaging stations in Chester County, Pennsylvania, from 1998-2009.

[Blue shading indicates flow less than the 90-percent flow duration; USGS, U.S. Geological Survey; $\mathrm{ft}^{3} / \mathrm{s}$, cubic feet per second]

\begin{tabular}{|c|c|c|c|c|c|c|}
\hline \multirow{5}{*}{ Year } & \multicolumn{6}{|c|}{ USGS streamgaging station } \\
\hline & 01472157 & 01473169 & 01475850 & 01480300 & 01480617 & 01480870 \\
\hline & \multicolumn{6}{|c|}{ 90-percent flow duration ( $\left.\mathrm{ft}^{3} / \mathrm{s}\right)$} \\
\hline & 20 & 14 & 5.7 & 6.7 & 25 & 41 \\
\hline & \multicolumn{6}{|c|}{ Mean daily discharge (September 1-November 30$)\left(\mathrm{ft}^{3} / \mathrm{s}\right)$} \\
\hline 1998 & 26 & 16 & 6.2 & 10 & 26 & 52 \\
\hline 1999 & 109 & 50 & 37 & 29 & 95 & 154 \\
\hline 2000 & 43 & 24 & 17 & 19 & 40 & 89 \\
\hline 2001 & 19 & 12 & 5.1 & 6.6 & 22 & 44 \\
\hline 2002 & 45 & 25 & 16 & 19 & 52 & 59 \\
\hline 2003 & 58 & 55 & 38 & 51 & 158 & 280 \\
\hline 2004 & 131 & 70 & 46 & 40 & 106 & 226 \\
\hline 2005 & 107 & 29 & 16 & 39 & 102 & 135 \\
\hline 2006 & 129 & 46 & 33 & 26 & 70 & 168 \\
\hline 2007 & 35 & 22 & 15 & 16 & 41 & 74 \\
\hline 2008 & 47 & 26 & 13 & 15 & 38 & 78 \\
\hline 2009 & 99 & 37 & 31 & 34 & 86 & 179 \\
\hline
\end{tabular}




\section{Sampling and Analytical Methods}

In an attempt to limit the variation in the data that were collected over a 12-year period, all field sampling methods remained consistent from 1998 to 2009. All sites were sampled for water-quality constituents and benthic macroinvertebrates annually in the fall (October-December) during base-flow conditions. The field personnel, as well as the equipment and sampling techniques used to collect all samples, remained unchanged. Some analytical detection limits reported by the U.S. Geological Survey National Water Quality Laboratory (NWQL) were changed over the 12-year sampling period, but the list of constituents and general analytical procedures remained consistent.

\section{Benthic Macroinvertebrates}

Benthic-macroinvertebrate samples from 1998 to 2009 were collected from riffles within a $100-\mathrm{m}$ reach, using a Hess sampler with a mesh size of 500 microns $(\mu \mathrm{m})$. A Hess sampler is a metal cylinder with a net attached to capture dislodged organisms (Merritt and Cummings, 1996). The metal cylinder is approximately $0.5 \mathrm{~m}$ in diameter and samples an area of $0.086 \mathrm{~m}^{2}$. Three samples were collected from areas of various velocities and depths and composited into a single sample. The samples were preserved in 95-percent ethanol and returned to the USGS office for sorting and identification. The entire sample was sieved through a $500-\mu \mathrm{m}$ sieve and sorted (organisms removed from sample debris) using a dissecting microscope. Organisms in the groups Nemata (nematodes) and Nemertea (proboscis worms) were identified to the phylum level. Organisms in the groups Plathyelminthes (flatworms) and Annelida (segmented worms) were identified to the family level. Organisms in the groups Mollusca (molluses), Arthropoda (arthropods) and Insecta (insects) were identified to the genus level, except for water mites (Hydrachnidae) and midges (Chironomidae) which were identified to the family level. If an organism could not be identified to its lowest taxonomic level because of size or condition, it was moved to the lowest taxonomic level where it could be positively identified. For metrics calculations, organisms that were not identified at their expected level were counted at the higher taxonomic level if no other organism was identified in the same taxonomic group. If organisms were identified in the same taxonomic group, the organisms that were not identified at their expected taxonomic level were split among the organisms that were identified at the lower taxonomic level. A list of taxonomic references on which identifications were based is given in table 6 .

\section{Field Characteristics}

Dissolved oxygen, $\mathrm{pH}$, water temperature, specific conductance, acid neutralizing capacity, and streamflow (when unavailable from a USGS streamgaging station) were
Table 6. Taxonomic groups and references used to identify them in benthic-macroinvertebrate samples.

\begin{tabular}{lc}
\hline \multicolumn{1}{c}{ Taxonomic group } & Reference \\
\hline $\begin{array}{l}\text { Turbellaria, Nemertea, Gastropoda, } \\
\text { Bivalvia, Annelida, Crustacea, }\end{array}$ & $\begin{array}{c}\text { Smith, 2001; Peckarsky } \\
\text { and others, 1990; Thorp } \\
\text { Hydrachnida }\end{array}$ \\
and Covich, 2001 \\
Ephemeroptera, Megaloptera, & Merritt and Cummings, \\
Neuroptera, Lepidoptera, & 1996 ; Peckarsky and \\
Coleoptera, Diptera & others, 1990 \\
Odonata & Peckarsky and others, \\
& $1990 ;$ Westfall and \\
& May, 1996 and 2000 \\
Plecoptera & Peckarsky and others, \\
& 1990; Stewart and \\
Trichoptera & Stark, 2002 \\
\hline
\end{tabular}

measured when biological samples were collected. Field meters were calibrated following USGS protocols (Wilde, variously dated), and all calibration information was recorded in meter log books. Dissolved oxygen, $\mathrm{pH}$, water temperature, and specific conductance were measured at three to five locations along a cross section within the 100-meter sampling reach. The median value for each characteristic was used as the value for that sampling event. Acid neutralizing capacity was determined by titration at the field site using USGS protocols (Rounds, 2006). Streamflow measurements were made concurrently with the collection of water-quality samples at all sampling sites that were not located at a USGS continuousrecord streamgaging station. Procedures for making streamflow measurements followed documented USGS procedures (Rantz and others, 1982).

\section{Nutrients, Major Ions, and Metals}

Water-quality samples for laboratory determination of nutrients, major ions, and metals were collected concurrently with biological samples following USGS protocols (U.S. Geological Survey, 2006). All sampling equipment was cleaned using techniques described by Wilde (2004). Water-quality samples were collected with a DH-81 hand-held sampler fitted with a plastic nozzle holder, plastic nozzle, and 1-liter (L) plastic bottle. Streamwater was collected from three to five equidistant depth-integrated verticals within the stream width. Each subsample was poured into a pre-cleaned and streamrinsed plastic churn splitter to create a depth- and widthintegrated composite sample. The locations of the verticals were noted on the field data sheets. In streams with insufficient depth to use a DH-81 sampler, an open bottle was used to collect the sub-samples. After mixing in the churn splitter, 
whole-water samples were transferred directly to pre-rinsed or pre-cleaned plastic bottles. Samples to be analyzed for dissolved constituents were filtered through a $0.45-\mu \mathrm{m}$ filter into pre-rinsed or pre-cleaned plastic bottles using a peristaltic pump with silicone tubing. All samples were immediately placed on ice and were shipped to the NWQL in Denver, Colorado, within 48 hours (Wilde and others 2004). All chemical analyses were performed by the NWQL using techniques described by Fishman and Friedman, (1989) (table 7).

\section{Habitat}

An assessment of the instream and riparian habitats in the 100-m biological sampling reach was conducted concurrently with biological sampling using a modified version of the U.S. Environmental Protection Agency (USEPA) Rapid Bioassessment Protocols (RBP) for riffle/run habitats (Barbour and others 1999). The habitat assessment involved an evaluation of 10 characteristics including epifaunal substrate (available cover), embeddedness (the amount of cobbles and larger-sized fractions buried in silt, sand, or mud), velocity/depth regime, channel alteration, sediment deposition, riffle frequency, channel-flow status, condition of banks, bank vegetation

Table 7. Constituents analyzed for in filtered water samples collected from selected streams in Chester County, Pennsylvania, 1998-2009, with laboratory methods, and reporting levels.

[Analyses were conducted at the U.S. Geological Survey National Water Quality Laboratory in Denver, Colo.; NWIS, National Water Information System; mg/L, milligrams per liter; $\mu \mathrm{g} / \mathrm{L}$, micrograms per liter; ICP, inductively coupled plasma; IC, ion chromatography; ISE, ion selective electrode; C, colorimetry]

\begin{tabular}{|c|c|c|c|c|}
\hline Compound name & $\begin{array}{c}\text { NWIS } \\
\text { parameter } \\
\text { code }\end{array}$ & $\begin{array}{l}\text { Laboratory } \\
\text { method }\end{array}$ & $\begin{array}{l}\text { Reporting } \\
\text { level }\end{array}$ & Units \\
\hline Calcium & 00915 & ICP & 0.022 & $\mathrm{mg} / \mathrm{L}$ \\
\hline Magnesium & 00925 & ICP & 0.011 & $\mathrm{mg} / \mathrm{L}$ \\
\hline Potassium & 00935 & ICP & 0.030 & $\mathrm{mg} / \mathrm{L}$ \\
\hline Sodium & 00930 & ICP & 0.060 & $\mathrm{mg} / \mathrm{L}$ \\
\hline Chloride & 00940 & $\mathrm{IC}$ & 0.060 & $\mathrm{mg} / \mathrm{L}$ \\
\hline Fluoride & 00950 & ISE & 0.040 & $\mathrm{mg} / \mathrm{L}$ \\
\hline Silica $\left(\right.$ as $\left.\mathrm{SiO}_{2}\right)$ & 00955 & ICP & 0.018 & $\mathrm{mg} / \mathrm{L}$ \\
\hline Sulfate & 00945 & $\mathrm{IC}$ & 0.090 & $\mathrm{mg} / \mathrm{L}$ \\
\hline Nitrogen, ammonia (as N) & 00608 & $\mathrm{C}$ & 0.010 & $\mathrm{mg} / \mathrm{L}$ \\
\hline Nitrate + Nitrite (as N) & 00631 & $\mathrm{C}$ & 0.020 & $\mathrm{mg} / \mathrm{L}$ \\
\hline Nitrite (as N) & 00613 & $\mathrm{C}$ & 0.001 & $\mathrm{mg} / \mathrm{L}$ \\
\hline Orthophosphate $\left(\mathrm{PO}_{4}\right)$ (as $\mathrm{P}$ ) & 00671 & $\mathrm{C}$ & 0.004 & $\mathrm{mg} / \mathrm{L}$ \\
\hline Boron & 01020 & ICP & 1.000 & $\mu \mathrm{g} / \mathrm{L}$ \\
\hline Iron & 01046 & ICP & 3.200 & $\mu \mathrm{g} / \mathrm{L}$ \\
\hline
\end{tabular}

protection, and riparian vegetative-zone width. All characteristics at a site were given qualitative values based on a 0 to 20 scale and were categorized as optimal (16-20), suboptimal (11-15), marginal (6-10), or poor (0-5). The value for each characteristic was combined for a total site habitat score.

\section{Quality Control}

One field-blank sample was collected annually to evaluate the potential for sample contamination during equipment preparation, sample collection, processing, and shipping. A field blank was collected at a sampling location at the same time as an environmental sample by pouring inorganic blank water through the field equipment and processing the collected sample through the filter apparatuses used for environmental samples. Inorganic blank water was supplied by the NWQL. Constituent concentrations in field blanks were usually lower than the minimum reporting levels, indicating that no systematic contamination issues were found for the blank samples (table 8).

Benthic-macroinvertebrate sorting efficiency was evaluated by the re-sorting of selected completed samples. Sorting efficiency evaluates how complete the removal of the

Table 8. Summary of constituents in blank samples collected at selected sites in the Stream Conditions of Chester County Biological Monitoring Network, 1998-2009.

[Analyses were conducted at the U.S. Geological Survey National Water Quality Laboratory in Denver, Colo.; --, no data; mg/L, milligrams per liter; $\mu \mathrm{g} / \mathrm{L}$, micrograms per liter]

\begin{tabular}{lcccc}
\hline \multicolumn{1}{c}{ Constituent } & $\begin{array}{c}\text { Parameter } \\
\text { code }\end{array}$ & $\begin{array}{c}\text { Number } \\
\text { of } \\
\text { samples }\end{array}$ & $\begin{array}{c}\text { Number of } \\
\text { detections } \\
\text { above } \\
\text { reporting } \\
\text { limit }\end{array}$ & $\begin{array}{c}\text { Concentration } \\
\text { range }\end{array}$ \\
\hline Calcium & 00915 & 9 & 2 & $0.032-0.155 \mathrm{mg} / \mathrm{L}$ \\
Magnesium & 00925 & 9 & 0 & -- \\
Potassium & 00935 & 9 & 0 & -- \\
Sodium & 00930 & 9 & 1 & $0.12 \mathrm{mg} / \mathrm{L}$ \\
Chloride & 00940 & 9 & 0 & -- \\
Fluoride & 00950 & 9 & 0 & -- \\
\hline Silica & 00955 & 9 & 0 & -- \\
Sulfate & 00945 & 9 & 0 & -- \\
Ammonia & 00608 & 9 & 1 & $0.040 \mathrm{mg} / \mathrm{L}$ \\
\hline Nitrate + Nitrite & 00631 & 9 & 1 & $0.040 \mathrm{mg} / \mathrm{L}$ \\
\hline Nitrite & 00613 & 9 & 1 & $0.002 \mathrm{mg} / \mathrm{L}$ \\
\hline Orthophosphate & 00671 & 9 & 0 & -- \\
\hline Iron & 01046 & 9 & 0 & -- \\
\hline Boron & 01020 & 9 & 2 & $16.3-19.4 \mu \mathrm{g} / \mathrm{L}$ \\
\hline
\end{tabular}


organisms from the sampling debris was during the original sorting. Any organisms or individuals that were consistently unsorted were added to the sample total, and training was conducted for the personnel responsible for sorting to improve sorting efficiency. A voucher collection (a specimen of each organism identified) is kept at the USGS office in Exton, Pennsylvania.

\section{Chester County Index of Biotic Integrity}

An IBI is a useful biological assessment tool for comparing the community-level biological components (structure, composition, and diversity) of a site to a reference condition. The reference condition refers to conditions at minimally disturbed or best attainable sites in the study area (Stoddard and others, 2006). Assessment of the biological condition requires an evaluation of biological responses at various scales, including individual organism response and community and ecosystem responses (Barbour and others, 1995). An IBI incorporates information on community structure and reduces it to a simple numerical value on the basis of different metrics that measure various aspects of community structure and function. A biological metric quantifies a measurable component of a biological community that responds to increased anthropogenic stress in a predictable direction (Barbour and others, 1995). Metrics are selected for an IBI on the basis of their ability to discriminate between sites that are known to be stressed and reference conditions. Multiple metrics are used in an IBI because an individual metric can be responsive to specific stressors. The multimetric approach increases the sensitivity to ecosystem stressors and minimizes any limitations that each individual metric may have, if used individually (Barbour and others, 1995). Using metrics that can indicate changes in minimally disturbed and highly disturbed streams allows for overlap that helps strengthen the overall conclusions reached using a multimetric approach (Barbour and others, 1995).

The PaDEP developed the Pa-IBI in 2007 to assist in the evaluation of Pennsylvania streams (Chalfant, 2007). This present study used the methods and metrics developed for the $\mathrm{Pa}$-IBI to establish the CC-IBI with data collected from the Network from 1998 to 2009. Sample collection and sorting techniques differed for the PaDEP samples and the USGS Chester County samples. PaDEP samples are a composite of six kick samples $\left(6 \mathrm{~m}^{2}\right)$. The composite was then subsampled to a 200 organism final sample. The USGS Chester County samples are a composite of three Hess samples $\left(0.258 \mathrm{~m}^{2}\right.$ total), and the composite was fully sorted. Because of the differences in sampling and sorting techniques, and metric reference values, the scores produced by the two IBIs are not directly comparable. Different sampling techniques can preferentially collect certain types of organisms (Lenz and Miller, 1996), and sub-sampling techniques remove only a small portion of the organisms collected and can exclude rare taxa (Courtemanche,1996).

\section{Chester County Index of Biotic Integrity Metrics}

The CC-IBI consists of the same six biological metrics used in the Pa-IBI - total taxa richness; modified Ephemeroptera, Plecoptera, Trichoptera (EPT) taxa richness; modified Hilsenhoff Biotic Index (HBI); Beck's Index (version 3); Shannon Diversity Index; and percent sensitive taxa. Total taxa richness and EPT taxa richness are measures of community structure and taxonomic diversity. These metrics represent the diversity within a sample, which is expected to increase with the increasing health of the community. A diverse biological community indicates that the water quality, habitat, and food resources are adequate to support a wide range of species. EPT taxa richness takes into consideration the diversity of specific groups that are generally considered pollution sensitive. HBI, Beck's Index, and percent sensitive taxa are measures of taxonomic composition that includes relative abundance, dominance, and sensitivity measures. These measures consider the relative abundance of individual organisms with respect to sensitivity to stressors. Shannon Diversity Index is also a measure of taxonomic composition that concerns the evenness of individuals in a sample, the loss of pollution-sensitive taxa, and the increasing dominance of a few pollution-tolerant taxa.

Pollution tolerance values (PTVs) are used in the determination of EPT taxa richness, Beck's Index, and percentsensitive individuals. PTVs are also used in the calculation of HBI values. PTVs are based on an organism's ability to survive in degraded environments. PTVs range from 0 (pollution sensitive) to 10 (pollution tolerant). A list of organisms' PTVs and references used in the CC-IBI is presented in appendix 1.

Calculated metrics included the following:

1. Community Structure Metrics (taxonomic richness)

- Total taxa richness is a measurement of the total number of taxa (taxonomic distinct organism) present. Total taxa richness is expected to decrease with increased stress to the stream ecosystem resulting from increasing dominance of a few pollution-tolerant taxa.

- Modified EPT taxa richness is a count of the number of taxa belonging to the orders Ephemeroptera (mayflies), Plecoptera (stoneflies), and Trichoptera (caddisflies). These taxonomic groups are generally considered pollution sensitive (Lenat and Penrose, 1996). Only EPT taxa with PTVs of 0 to 4 are counted. EPT taxa richness generally decreases with increasing ecosystem stress.

2. Taxonomic Composition Metrics (diversity and pollution tolerance)

- Modified HBI is an average PTV weighted by the number of individuals of each taxon in the sample. The range of values is 0 to 10 ; values generally increase with increasing ecosystem stress (Hilsenhoff 1987). 
- Beck's Index (version 3) is a weighted count of taxa with PTVs of 0,1 , or 2 (pollution-sensitive organisms). This metric is derived from Beck (1955). Values generally decrease with increasing ecosystem stress.

- Shannon Diversity is a community composition metric that measures taxonomic richness and evenness of individuals across taxa (Shannon and Weaver, 1949). This metric generally decreases with increasing ecosystem stress.

- Percent sensitive individuals (PTV 0-3) is a community composition and tolerance metric based on the percentage of individuals with PTVs 0 to 3 . This metric generally decreases with increasing ecosystem stress.

Total taxa richness, EPT taxa richness, and HBI are metrics that have been used historically in the evaluation of data from the Network (Reif, 2002).

\section{Reference Condition}

The determination of a benchmark or reference condition is a critical step in the development and implementation of an IBI. This reference condition represents the least disturbed or best available conditions that will be used in a comparison to other streams (Barbour and others, 1999). Reference conditions can be determined by numerous methods including sampling of minimally disturbed sites, professional judgment, and empirical models (Stoddard and others 2006). Comparison of a sampling site to reference conditions not found in the sampling area can create an unreasonable expectation of what is attainable at the local sites.

Reference values used in the Pa-IBI were not used in the CC-IBI because they were developed with data collected using different sampling and sorting techniques from those used in the Network streams. Also, the Pa-IBI reference values were developed from reference streams throughout Pennsylvania that are unlike most streams found in Chester County (Chalfant, 2007). If the Pa-IBI reference values had been used, the resulting CC-IBI may have referenced an unattainable baseline condition.

The reference values used to calibrate the CC-IBI did not rely on the traditional use of reference sites but relied on data collected in Chester County from 1998 to 2009. This novel approach eliminates the need for specific reference sites and uses the highest measured metric values from the 320 samples collected in Chester County from 1998 to 2009. The metrics that decrease in value with increasing ecosystem stress (total taxa richness, EPT taxa richness, Beck's Index, Shannon Diversity Index, and percent sensitive individuals) were ranked, and the 95 th percentile of the 320 samples was determined. The values at the 95 th percentile were used to standardize each metric in the CC-IBI calculations and are considered the standardization (reference) value for the CC-IBI. The metric that increases in value with increasing ecosystem stress (HBI) was ranked, and the 5th percentile was determined. The HBI value at the 5 th percentile was used to standardize the HBI metric in the CC-IBI calculations and is considered the standardization (reference) value for the CC-IBI. A summary of all metric standardization (reference) values is listed in table 9 .

For 22 of the 102 sites sampled from 1998 to 2009, at least 1 of the 6 metric scores was within the top 5 percent of all scores for that metric. These sites included fixed-location and flexible-location sites that were primarily located in the north and central part of Chester County. The sites with numerous metric values within the top 5 percent are Pigeon Creek (site 10, 01472080), French Creek (site 15, 01472157), Buck Run (site 46, 01480629), East Branch Brandywine at Glenmoore, Pa. (site 42, 01480653), Indian Run (site 85, 01480658), and Marsh Creek (site 86, 01480675).

This method removes the need for selection of a specific reference site or any professional judgment; it relies on the best available conditions found in Chester County during the sampling period. It also removes the unrealistic comparison of Chester County streams to non-similar reference streams outside the local area.

\section{Chester County Index of Biotic Integrity Calculations}

The final CC-IBI index score provides a way to integrate information from the six individual metrics into a single value. The six metrics are a mix of taxa counts, percentages, and unitless numbers. For five of the six metrics, a decreased value is associated with increasing ecosystem stress. However, a decreased HBI value is associated with decreasing ecosystem stress. In order to combine the six metrics into a single value,

Table 9. Metric standardization values for the six metrics used to calculate the Chester County Index of Biotic Integrity value.

[EPT, Ephemeroptera, Plecoptera, Trichoptera; PTV, Pollution tolerance value]

\begin{tabular}{lcc}
\hline \multicolumn{1}{c}{ Metric } & $\begin{array}{c}\text { Standardization } \\
\text { value }\end{array}$ & $\begin{array}{c}\text { Standardization } \\
\text { percentile }\end{array}$ \\
\hline Total taxa richness & 50 & 95 \\
EPT taxa richness (PTV 0-4) & 19 & 95 \\
Hilsenhoff Biotic Index & 3.98 & 5 \\
Beck's Index & 26 & 95 \\
$\begin{array}{l}\text { Shannon Diversity Index } \\
\begin{array}{l}\text { Percent sensitive individuals } \\
\text { (PTV 0-3) }\end{array}\end{array}$ & 2.87 & 95 \\
\hline
\end{tabular}


it is necessary to standardize (deviation from the reference value) the metrics so that the results are in a standard form and to preform mathematical transformations so that results are in a logical progression.

The metrics were standardized using the standardization values listed in table 9. Each individual metric score for the test sites was divided by the standardization value for that metric to give a percentage. This percentage represents the similarity of the individual metric score for the test site to the standardization value. The resulting standardized values were limited to a maximum of 1.00 with values closer to 1.00 representing conditions similar to the reference condition. As values deviate from 1.00 , conditions are degrading from the reference condition. The adjusted standardized metric values for the six metrics are averaged and multiplied by 100 to produce an index score that ranges from 0 to 100 . This value is the final CC-IBI score for an individual sample. A complete list of all CC-IBI values and individual metric scores is given in appendix 2.

An example CC-IBI calculation is provided below that uses the data from a sample collected on October 18, 2004, from site 1, Pickering Creek near Eagle (01472170; table 10).

Table 10. Example of standardization and Chester County Index of Biotic Integrity scoring calculation for the sample collected on October 18, 2004, from site 1 (01472170) Pickering Creek near Eagle, Pennsylvania.

[EPT, Ephemeroptera, Plecoptera, Trichoptera; PTV, Pollution tolerance value]

\begin{tabular}{llcc}
\hline \multicolumn{1}{c}{ Metric } & \multicolumn{1}{c}{ Standardization equation } & Observed value & $\begin{array}{c}\text { Standardized } \\
\text { metric score }\end{array}$ \\
\hline Total taxa richness & Observed value / 50 & 40 & 0.80 \\
EPT taxa richness (PTV 0-4) & Observed value / 19 & 16 & 0.84 \\
Hilsenhoff Biotic Index & $(10-$ observed value) / (10-3.98) & 4.77 & 0.87 \\
Beck's Index & Observed value / 26 & 16 & 0.62 \\
Shannon Diversity Index & Observed value / 2.87 & 2.45 & 0.85 \\
Percent sensitive individuals (PTV 0-3) & Observed value / 43.07 & 26.76 & 0.62 \\
\hline \multicolumn{2}{c}{ Average of standardized metric scores = } & $\mathbf{7 6 . 6 7}$ \\
\hline
\end{tabular}

- Total taxa richness is a total count of all taxa in the sample.

- Total taxa richness $=40$

- Modified EPT taxa richness (0-4 PTV) is the number of taxa belonging to the insect orders Ephemeroptera, Plecoptera, or Trichoptera that have a PTV of 0 to 4 (table 9).

- EPT taxa richness $=16$ 


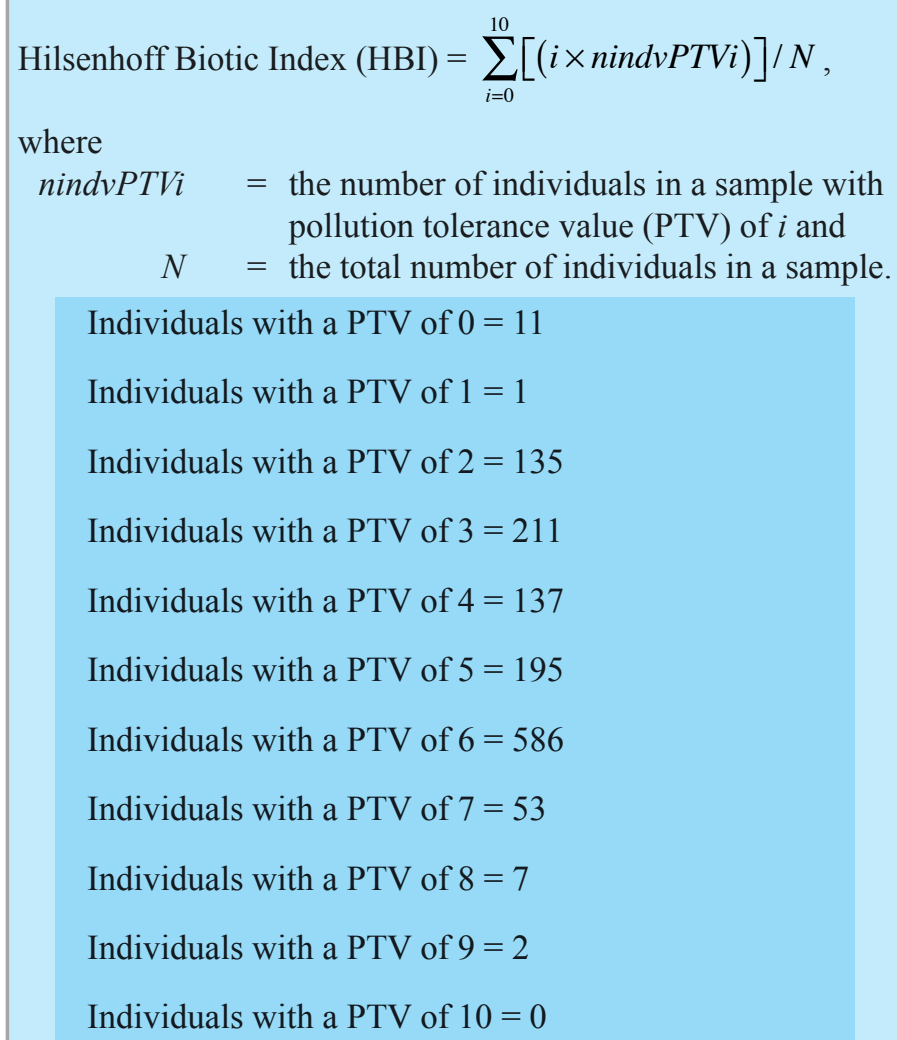
pollution tolerance value (PTV) of $i$ and

There were 1,338 total individuals in the sample.

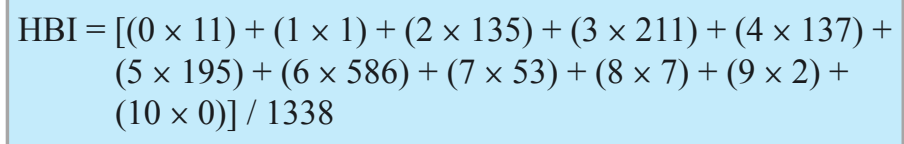
pollution tolerance value (PTV) of $i$.

Taxa with a PTV of $0=3$

Taxa with a PTV of $1=1$

Taxa with a PTV of $2=5$

Beck's Index $=3(3)+2(1)+1(5)=16$
Shannon Diversity Index $=-\sum_{i=1}^{R i c h}\left(n_{i} / N\right) \ln \left(n_{i} / N\right)$, where

$$
\begin{aligned}
n_{i}= & \text { the number of individuals in each taxon } \\
& \text { (relative abundance), } \\
N= & \text { the total number of individuals in the } \\
& \text { sample (total taxa richness), } \\
\text { Rich }= & \text { the total number of taxa in the sample } \\
& \text { (total taxa richness). }
\end{aligned}
$$

There are 40 taxa and 1,338 individuals in the sample (first taxa had 2 individuals, the 40th taxa had 13 individuals).

Shannon Diversity Index $=-(2 / 1,338) \ln (2 / 1,338)+$

$(3 / 1,338) \ln (3 / 1,338)+(7 / 1,338) \ln (7 / 1,338)+\ldots$

$(9 / 1,338) \ln (9 / 1,338)+(13 / 1,338) \ln (13 / 1,338)=$ 2.45

Percent sensitive individuals (PTV 0-3) $=\frac{\sum_{i=0}^{3} n i n d v P T V i}{N} \times 100$ where,

nindvPTVi $=$ the number of individuals in a sample with pollution tolerance value (PTV) of $i$ and

$N=$ the total number of individuals in a sample.

Individuals with a PTV of $0=11$

Individuals with a PTV of $1=1$

Individuals with a PTV of $2=135$

Individuals with a PTV of $3=211$

There are 358 total individuals with a PTV of 0 to 3 in the sample of 1,338 total individuals.

Percent sensitive individuals $($ PTV $0-3)=(358 / 1,338) \times 100$

Percent sensitive individuals $($ PTV $0-3)=0.2676 \times 100$

Percent sensitive individuals (PTV 0-3) $=26.76$ percent 


\section{Assessment of Stream Conditions in Chester County, 1998-2009}

The CC-IBI is the overall assessment tool used to evaluate the stream quality of a sampling location on the basis of the benthic-macroinvertebrate community found at a site. Field characteristics, chemical analysis, habitat evaluation, and land-use data are used to evaluate and predict the factors that determine the CC-IBI score at an individual site.

\section{Benthic Macroinvertebrates}

Benthic macroinvertebrates act as integrators of the physical and chemical conditions at a location and the overall stream quality is determined by the benthic-macroinvertebrate community found at a site. A statistical summary of CC-IBI results from samples collected from 1998 to 2009 at the 18 fixed-location sites is presented in table 11. Complete results for all samples collected are presented in appendix 2 .

CC-IBI scores represent the individual metric scores obtained for a site in comparison to the top 5 percent of individual metric scores (reference condition) for the 320 samples collected from 1998 to 2009. CC-IBI scores greater than 90 indicate that the benthic-macroinvertebrate communities are similar to the reference condition. Sites with CC-IBI scores greater than 90 have a diverse population of pollutionsensitive organisms, including mayflies, stoneflies, and caddisflies. As CC-IBI scores decrease below 90, the benthicmacroinvertebrate communities have decreasing similarity to the reference conditions. The sites with scores less than 90 generally have fewer pollution-sensitive organisms $(\mathrm{PTV}<3$ ) and increased numbers of pollution-intolerant organisms (PTV 7). These sites become increasingly dominated by a few taxa, such as riffle beetles (Elmidae) and net-spinning caddisflies (Hydropsychidae) and may support a large number of individuals. As CC-IBI scores fall below 50, the sites generally are dominated by pollution-tolerant taxa including midges and worms, and are often lacking any mayfly or stonefly taxa.

At the 18 fixed-location sites the mean CC-IBI values ranged from 37.21 at the West Branch Brandywine at Modena (site 56, 01480617) to 88.92 at French Creek (site 15, 01472157; table 11). Six of the 18 fixed-location sites had a mean CC-IBI score less than 50, seven sites had a score of 50 to 70, and five sites had a score greater than 70 (fig. 4). Thirtynine percent of the 213 samples collected at the 18 fixedlocations sites had a CC-IBI score less than 50,33 percent had a score of 50 to 70 , and 28 percent had a score greater than 70 (fig. 5).

Table 11. Statistical summary of Chester County Index of Biotic Integrity scores from 18 fixed-location sites in the Stream Conditions of Chester County Biological Monitoring Network, Chester County, Pennsylvania, 1998-2009.

[USGS, U.S. Geological Survey; CC-IBI, Chester County Index of Biotic Integrity]

\begin{tabular}{|c|c|c|c|c|c|c|c|}
\hline $\begin{array}{c}\text { USGS } \\
\text { station } \\
\text { number }\end{array}$ & $\begin{array}{c}\text { USGS } \\
\text { site } \\
\text { identifier }\end{array}$ & Stream & $\begin{array}{l}\text { Number of } \\
\text { samples }\end{array}$ & $\begin{array}{c}\text { 1998-2009 } \\
\text { mean } \\
\text { CC-IBI }\end{array}$ & $\begin{array}{c}\text { Maximum } \\
\text { CC-IBI }\end{array}$ & $\begin{array}{l}\text { Minimum } \\
\text { CC-IBI }\end{array}$ & $\begin{array}{c}\text { Median } \\
\text { CC-IBI }\end{array}$ \\
\hline 01472080 & 10 & Pigeon Creek near Slonaker, $\mathrm{Pa}$. & 12 & 81.75 & 97.95 & 60.77 & 81.12 \\
\hline 01472157 & 15 & French Creek near Phoenixville, Pa. & 12 & 88.92 & 96.45 & 74.60 & 90.26 \\
\hline 01472190 & 5 & Pickering Creek near Phoenixville, $\mathrm{Pa}$. & 12 & 73.72 & 86.57 & 59.24 & 74.14 \\
\hline 01473169 & 52 & Valley Creek at PA Turnpike Br. near Valley Forge, Pa. & 12 & 42.83 & 52.66 & 36.45 & 42.09 \\
\hline 01476450 & 81 & Ridley Creek at Rt. 3 near Willistown, Pa. & 9 & 55.38 & 64.08 & 45.73 & 55.33 \\
\hline 01476835 & 24 & East Branch Chester Creek at Westtown, Pa. & 12 & 45.91 & 59.14 & 38.32 & 44.78 \\
\hline 01478120 & 28 & East Branch White Clay Creek at Avondale, Pa. & 12 & 53.06 & 66.63 & 45.13 & 51.02 \\
\hline 01478230 & 58 & Middle Branch White Clay Creek near Avondale, Pa. & 12 & 58.87 & 75.03 & 44.30 & 58.54 \\
\hline 01480617 & 56 & West Branch Brandywine Creek at Modena, Pa. & 12 & 37.21 & 46.38 & 29.93 & 37.66 \\
\hline 01480629 & 46 & Buck Run at Doe Run, Pa. & 12 & 81.24 & 95.39 & 66.95 & 81.94 \\
\hline 01480653 & 42 & East Branch Brandywine Creek at Glenmoore, $\mathrm{Pa}$. & 12 & 84.02 & 94.81 & 64.59 & 84.33 \\
\hline 01480870 & 54 & East Branch Brandywine Creek below Downingtown, $\mathrm{Pa}$. & 12 & 58.43 & 73.31 & 34.10 & 60.95 \\
\hline 01494953 & 59 & Big Elk Creek at Maple Grove, Pa. & 12 & 42.70 & 58.37 & 26.41 & 44.02 \\
\hline 01578347 & 60 & East Branch Octoraro Creek near Steelville, Pa. & 12 & 65.84 & 77.80 & 56.37 & 64.81 \\
\hline
\end{tabular}




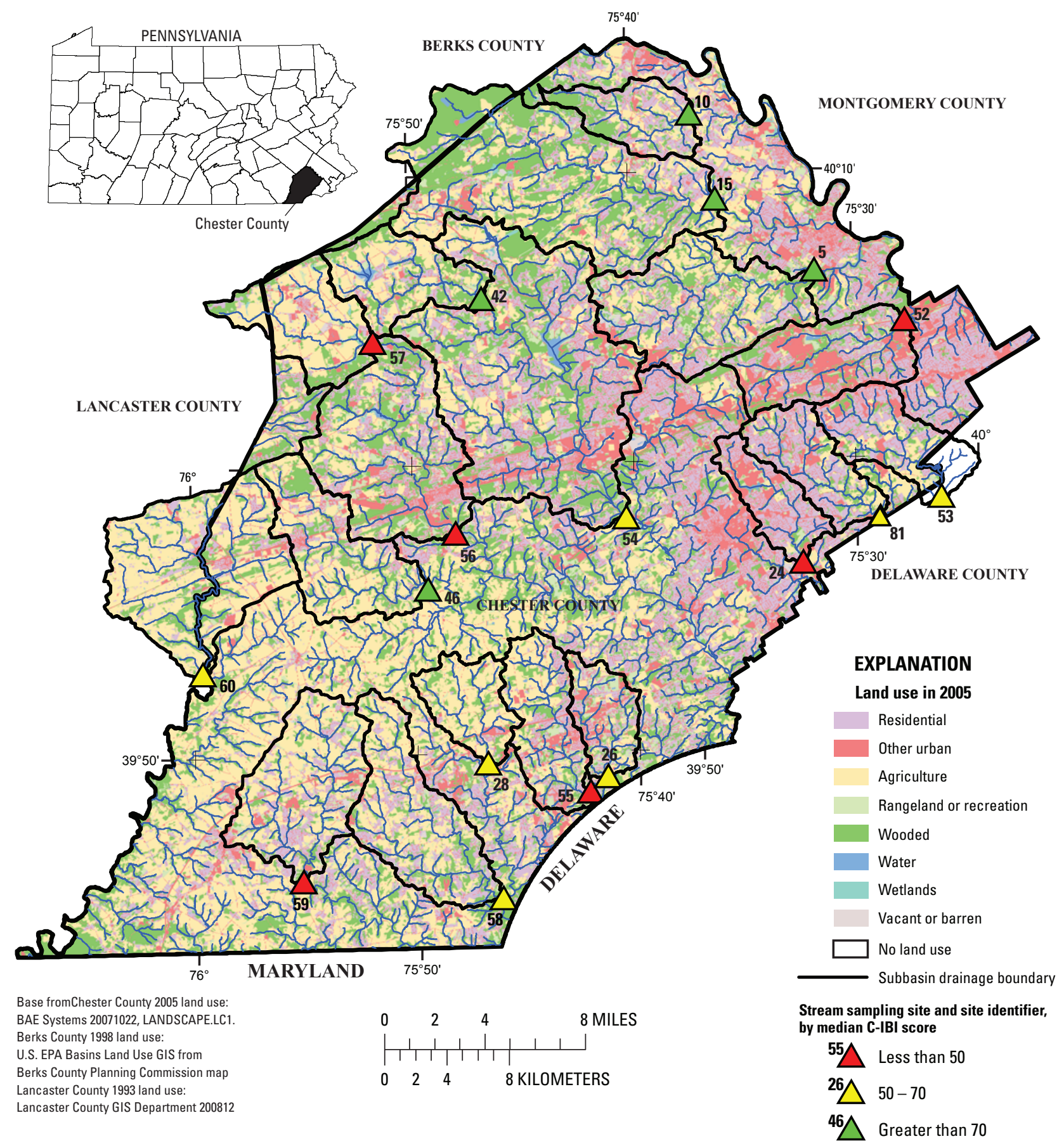

Figure 4. Sites categorized by range of mean Chester County Index of Biotic Integrity (CC-IBI) score, and generalized land use at 18 fixed-location sites, in the Stream Conditions of Chester County Biological Monitoring Network, Chester County, Pennsylvania, 1998-2009. (Parts of Berks, Delaware, Lancaster, and Montgomery Counties are included in the study area where they contributed to the drainage area at a sampling site). 


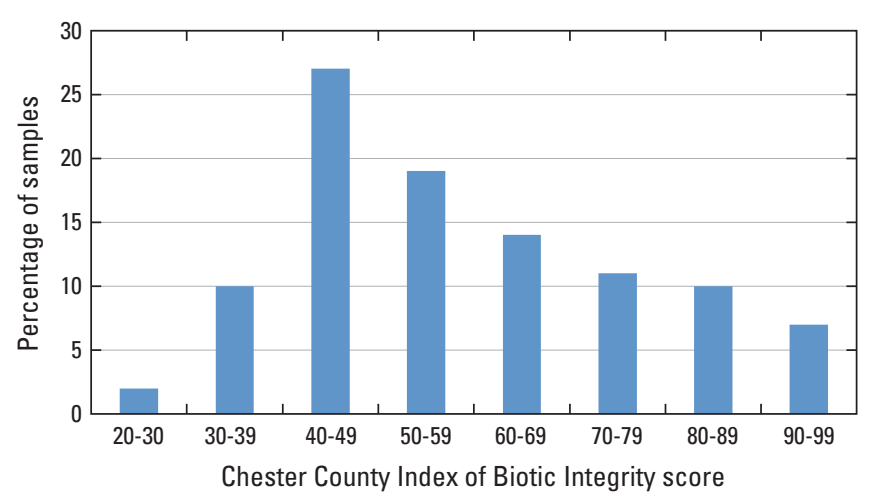

Figure 5. Percentage of 213 samples collected from 18 fixedlocation sites in the Stream Conditions of Chester County Biological Monitoring Network, Chester County, Pennsylvania, 1998-2009, by Chester County Index of Biotic Integrity score category.

CC-IBI scores for the 84 flexible-location sites sampled from 1998 to 2009 ranged from 23.48 at Trout Run (site 82, 01478137) to 99.96 at Marsh Creek (site 86, 01480675; appendix 2) with a mean score of 63.57. Twenty-five percent of the 107 samples collected at the flexible-location sites had a CC-IBI score less than 50; 33 percent, 50 to 70; and 42 percent, greater than 70 (fig. 6). More flexible-location sites (42 percent) scored greater than 70 than fixed-location sites ( 28 percent); this could be due to the fact that many of the flexible-location sites are in small headwater streams that were not affected by point wastewater discharges. The 18 fixed-location sites, in general, are in large streams with integrated multiple land uses that often received some type of point discharge. Approximately 68 percent of the 320 samples collected at both fixed-location and flexible-location sites from 1998 to 2009 had CC-IBI scores less than 70, indicating that the biological communities were substantially altered from the reference conditions.

\section{Field Characteristics}

Measurements of dissolved oxygen, $\mathrm{pH}$, specific conductance, and water temperature were made in the field for all samples. The measurements were made in the field because of the unstable nature of the characteristics. Dissolved oxygen, $\mathrm{pH}$, and water temperature vary naturally over a 24-hour period, making the comparison of annual point measurements difficult. A summary of the mean values of field measurements for samples collected at the 18 fixed-location sites is presented in table 12. Complete results for all samples collected are presented in appendix 3 .

Dissolved oxygen concentrations in the 320 samples collected from 1998 to 2009 ranged from 6.4 milligrams per liter $(\mathrm{mg} / \mathrm{L})$ at West Branch Red Clay Creek (site 55, 01479700) to

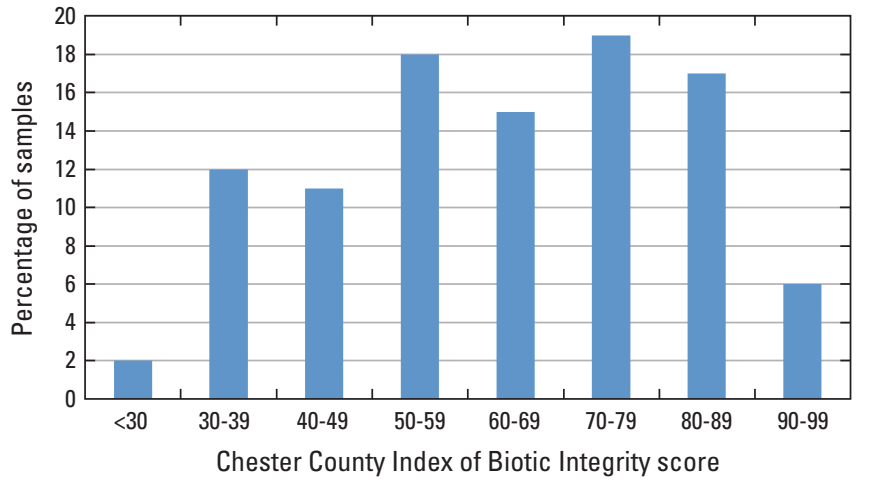

Figure 6. Percentage of 107 samples collected at flexiblelocation sites in the Stream Conditions of Chester County Biological Monitoring Network, Chester County, Pennsylvania, 1998-2009, by Chester County Index of Biotic Integrity score category. $(<$, less than)

$16.2 \mathrm{mg} / \mathrm{L}$ at Pickering Creek (site 5, 01472190). The dissolved oxygen measurements were made during the daylight hours when diel swings in dissolved oxygen are highest and, therefore, do not represent the full range of dissolved oxygen values that occur at a site. No dissolved oxygen measurements were less than the USEPA minimum recommendation level of $5.0 \mathrm{mg} / \mathrm{L}$ (U.S. Environmental Protection Agency, 1986a). Measurements of $\mathrm{pH}$ for the 320 samples ranged from 6.2 at East Branch Big Elk Creek (site 62, 01494800) to 8.9 at West Branch Brandywine Creek at Modena, Pa. (site 56, 01480617). Ninety-eight percent of the $320 \mathrm{pH}$ measurements were within the USEPA secondary drinking-water standard range of 6.5 to 8.5 (U.S. Environmental Protection Agency, 1992). The $\mathrm{pH}$ measurements were made during the daylight hours when diel swings in $\mathrm{pH}$ are highest and, therefore, do not represent the full range of $\mathrm{pH}$ values that occur at a site. Water temperatures for the 320 samples ranged from 1.6 degrees Celsius $\left({ }^{\circ} \mathrm{C}\right)$ at Big Elk Creek (site 59, 01494953) to $19.0^{\circ} \mathrm{C}$ at West Branch Brandywine Creek near Honey Brook, Pa. (site 57, 01480300).

Specific conductance is a measure of the capacity of dissolved ions in water to conduct an electric current (Wilde and others, 1998) and is an indirect method of measuring dissolved solids (Hem, 1985). Specific conductance for the 320 samples ranged from $83 \mu \mathrm{S} / \mathrm{cm}$ at North Branch Birch Run (site 93, 01480389 ) to $860 \mu \mathrm{S} / \mathrm{cm}$ at Valley Creek (site 72,01473160 ). Specific conductance is influenced by both geologic setting and land use in a basin. Limestone in the geologic setting and human disturbance can cause increased ion concentrations in the water, resulting in high specific conductance values $(>300 \mu \mathrm{S} / \mathrm{cm})$. Mean specific conductance values were lowest in the areas of Chester County with the lowest urban land use and increased with increasing urbanization (fig. 7). Specific conductance values were highest in the Valley Creek subbasin because of the presence of limestone and the prevalence of urban land use. 


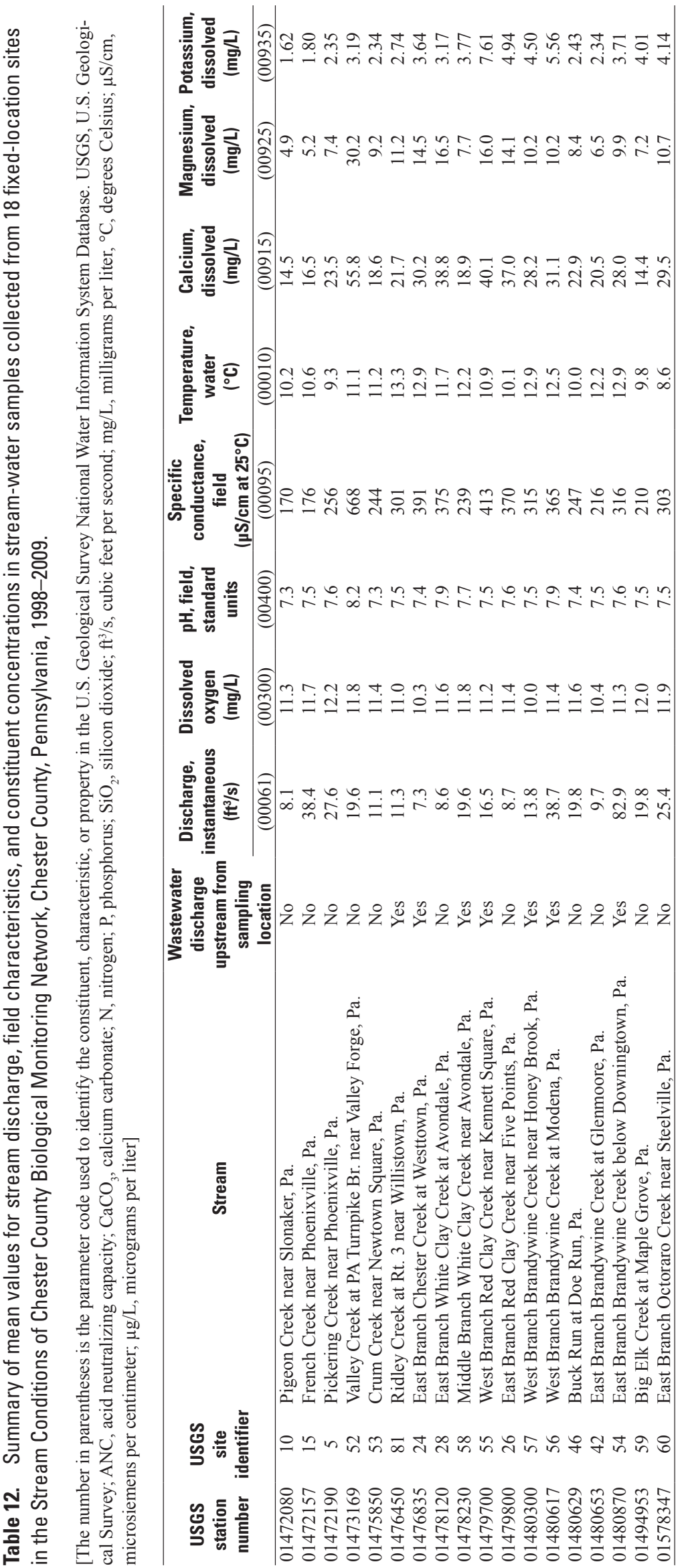

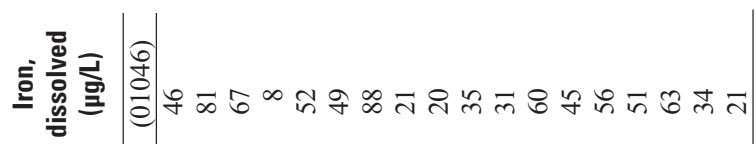

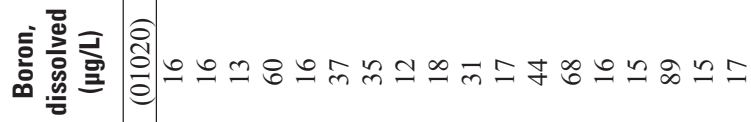

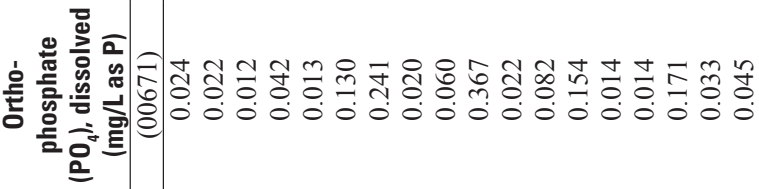

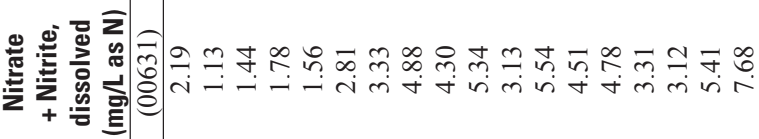

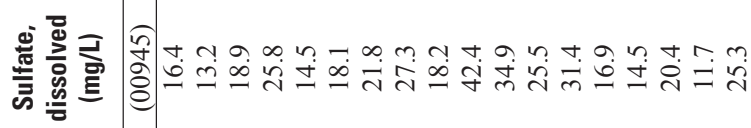

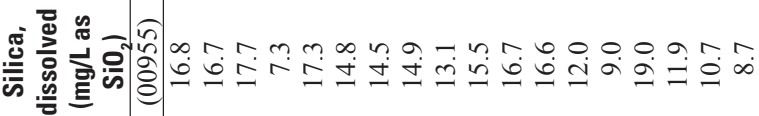

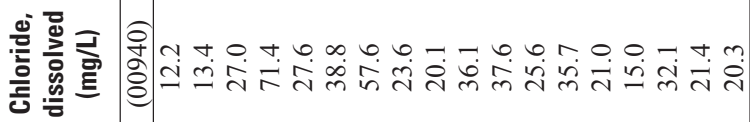

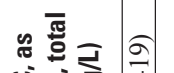

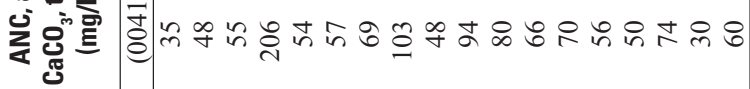

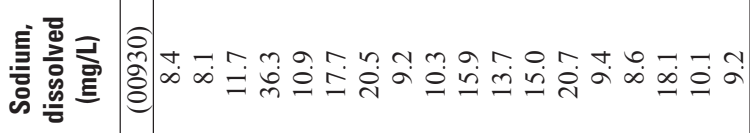

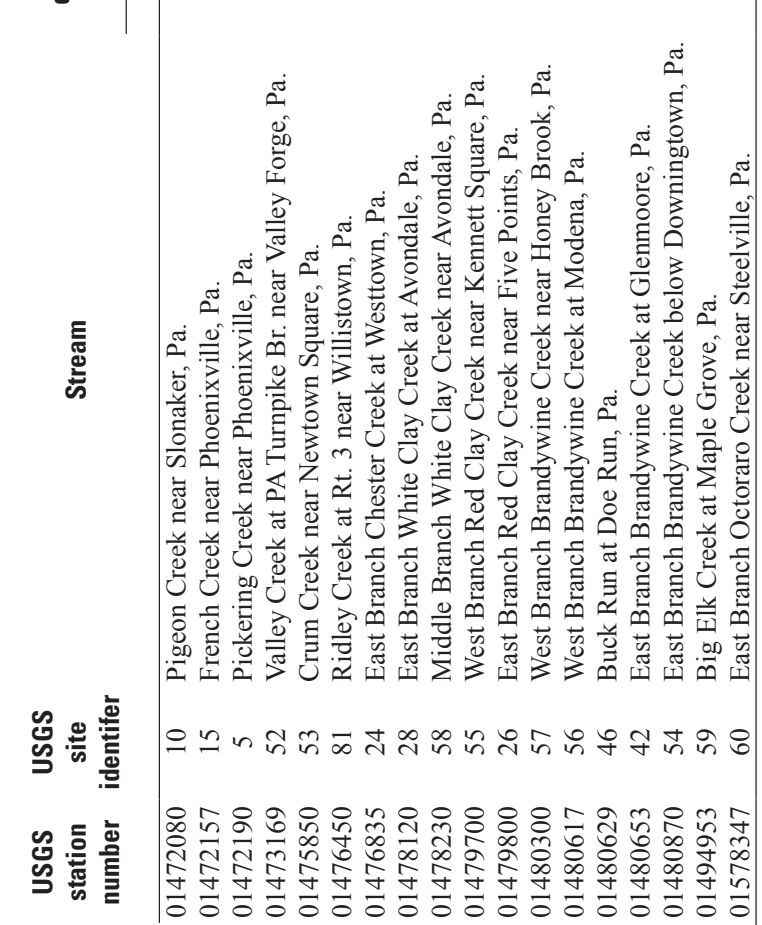




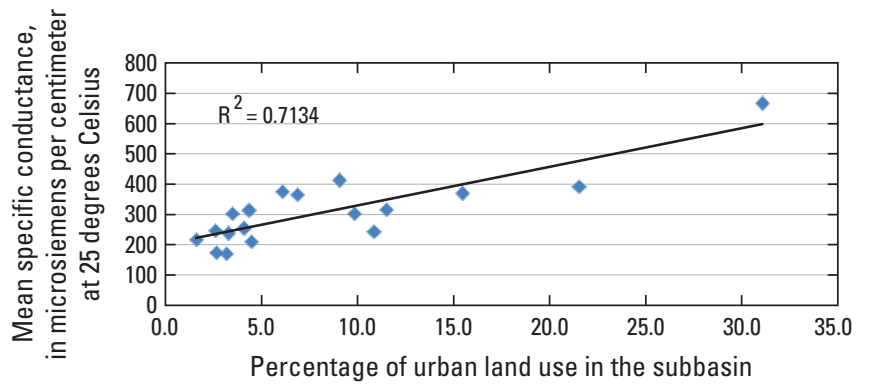

Figure 7. Relation of percentage of urban land use in the subbasin to mean specific conductance for samples collected at 18 fixed-location sites in the Stream Conditions of Chester County Biological Monitoring Network, Chester County, Pennsylvania, 1998-2009.

\section{Chemical Analysis}

Chemical constituents can affect benthic-macroinvertebrate communities and alter the CC-IBI score for a sample. Samples for analysis of nutrients (nitrogen and phosphorus), major ions, and selected metals were collected along with samples for benthic-macroinvertebrate analysis. A summary of mean concentrations for selected chemical constituents in samples collected at the 18 fixed-location sites is presented in table 12. Complete results for all samples are presented in appendix 3 .

\section{Nutrients}

Nutrients, including nitrogen- and phosphorus-based compounds, are required for plant growth and are found naturally in all aquatic systems. Nutrients analyzed for in samples are dissolved ammonia $\left(\mathrm{NH}_{4}^{+}\right)$, nitrate $\left(\mathrm{NO}_{3}^{-}\right)$, nitrite $\left(\mathrm{NO}_{2}{ }^{-}\right)$, and orthophosphate $\left(\mathrm{PO}_{4}{ }^{3-}\right)$. Anthropogenic sources of nutrients include fertilizer applications, wastewater discharges, leachate from onsite wastewater disposal (septic systems), and fossil-fuel emissions (U.S. Geological Survey, 1999). Nutrients can enter the aquatic system through various pathways, including agricultural and urban applications of fertilizer, agricultural applications of manure, and point-source discharges, such as wastewater discharge, combined sewer overflows, groundwater discharge, and atmospheric deposition (U.S. Geological Survey, 1999).

Ammonia concentrations were less than the detection level $(<0.02 \mathrm{mg} / \mathrm{L})$ at most sites; the maximum concentration of $1.92 \mathrm{mg} / \mathrm{L}$ was measured in a sample from West Branch Red Clay Creek (site 55, 01479700) in 2000 (appendix 3). The USEPA has set aquatic-life criteria for ammonia in surface waters at 0.07 to $2.1 \mathrm{mg} / \mathrm{L}$ ammonia-nitrogen, depending on water temperature and $\mathrm{pH}$ (U.S. Environmental Protection Agency, 1986b).

Mean nitrate concentrations at the 18 fixed-location sites ranged from $1.13 \mathrm{mg} / \mathrm{L}$ at French Creek (site 15, 01472157) to
$7.68 \mathrm{mg} / \mathrm{L}$ at East Branch Octoraro Creek (site 60, 01578347) (table 12). The maximum concentration of nitrate $(21.3 \mathrm{mg} / \mathrm{L})$ was measured in a sample from an unnamed tributary to Beaver Creek Reservoir at Reeceville, Pa. (site 97,014807434) in 2005. Site 97 is a small headwater stream in an agricultural subbasin where biosoilds were applied to the fields. The discharge measured at the Beaver Creek sites in 2005 was 4 times the flow measured during 2001 sampling (U.S. Geological Survey, 2009). The increased groundwater flow during the high base-flow period prior to sampling in 2005 may have contributed more nutrients to the subbasin. The streams with fixed-location sites with mean nitrate concentrations greater than the mean nitrate concentration for the 18 fixed-location sites $(3.68 \mathrm{mg} / \mathrm{L})$ were the West Branch Brandywine Creek (site 56, 01480617 and site 57, 01480300), Buck Run (site 46, 01480629), West Branch Red Clay Creek (site 55, 01479700), White Clay Creek (site 28, 01478120 and site 58, 01478230), Big Elk Creek (site 59, 01494953), and East Branch Octoraro Creek (site 60, 01578347) (table 12). These eight sites are in subbasins that contain a mixture of agricultural lands, including farms to which animal waste are applied and farms to which chemical fertilizers are applied, and intensively operated mushroom farms in the Red and White Clay Creek subbasins (fig. 3). Sites on the West Branch Brandywine, Middle Branch White Clay, and West Branch Red Clay Creeks also receive municipal wastewater discharge upstream from the sampling sites. East Branch Brandywine Creek at Glenmoore (site 42, 01480653) was the only site that had greater than 30 percent agricultural land use and a mean nitrate concentration less than $3.68 \mathrm{mg} / \mathrm{L}$.

Mean orthophosphate concentrations at the 18 fixed-location sites ranged from $0.012 \mathrm{mg} / \mathrm{L}$ at Pickering Creek (site 5, 01472190) to $0.367 \mathrm{mg} / \mathrm{L}$ at West Branch Red Clay Creek (site 55,01479700 ), which also had the maximum concentration of $0.846 \mathrm{mg} / \mathrm{L}$ in 1998 (appendix 3). West Branch Brandywine at Modena, Pa. (site 56, 01480617), East Branch Brandywine Creek below Downingtown, Pa. (site 54, 01480870), East Branch Chester Creek at Westtown, Pa. (site 24, 01476835), West Branch Red Clay Creek near Kennett Square, Pa. (site 55, 01479700), and Ridley Creek near Willistown, Pa. (site 81, 01476450) had mean orthophosphate concentrations greater than the USEPA's goal of $0.10 \mathrm{mg} / \mathrm{L}$ to prevent excessive plant growth (U.S. Environmental Protection Agency, 1994). All five sites have a municipal wastewater discharge (phosphorus source) within 10 miles upstream from the sampling site.

In general, nutrient concentrations were higher in subbasins where agriculture accounts for greater than 30 percent of the land use or in areas affected by wastewater-treatment discharges. Nitrate concentrations greater than $3.0 \mathrm{mg} / \mathrm{L}$ were associated with agricultural land use greater than 30 percent and municipal wastewater-treatment discharges upstream from the sampling location (fig. 8). Ortho-phosphate concentrations greater than $0.10 \mathrm{mg} / \mathrm{L}$ generally were associated with sites that had municipal wastewater discharges upstream from the sampling location (fig. 9). Ammonia was rarely found at concentrations greater than the detection limit of $0.02 \mathrm{mg} / \mathrm{L}$. 


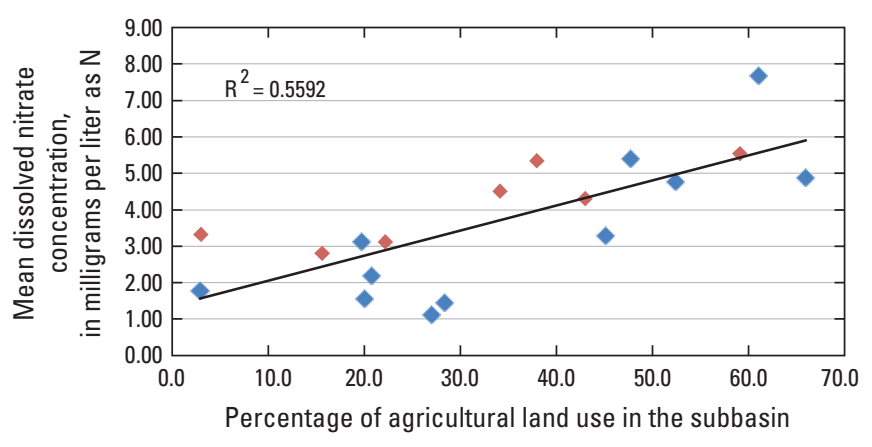

EXPLANATION

- No municipal wastewater discharges within 10 miles upstream from site

- Municipal wastewater discharge within 10 miles upstream from site

Figure 8. Relation of percentage of agricultural land use in the subbasin to mean dissolved nitrate concentration for samples collected at 18 fixed-location sites in the Stream Conditions of Chester County Biological Monitoring Network, Chester County, Pennsylvania, 1998-2009.

\section{Major lons and Metals}

The major ions and metals analyzed for are dissolved calcium, magnesium, potassium, sodium, chloride, silica, sulfate, boron, and iron (table 12). These constituents are naturally occurring, originate in the soil and rocks, and are contained in typical groundwater discharge to a stream. Anthropogenic sources of major ions and metals include road-salt applications, agricultural activities, wastewater discharges, and onsite-wastewater-disposal (septic) systems.

The mean chloride concentrations at the 18 fixed-location sites ranged from $12.2 \mathrm{mg} / \mathrm{L}$ at Pigeon Creek (site 10, 01472080) to $71.4 \mathrm{mg} / \mathrm{L}$ at Valley Creek (site 52, 01473169; table 12). Chloride concentrations at the 84 flexible-location sites sampled from 1998 to 2009 ranged from $6.7 \mathrm{mg} / \mathrm{L}$ at French Creek at Trythall (site 41, 01472126) to $112 \mathrm{mg} / \mathrm{L}$ at Trout Creek near Port Kennedy, Pa. (site 101, 01473210; appendix 3). The high concentrations of chloride at Valley Creek (sites 52, 71, 72, and 73) and Trout Creek are due to a combination of the presence of limestone and human disturbance. Other major ions follow a similar pattern of occurrence to that of chloride with higher concentrations in areas with agricultural land use, urban land use, or point discharges.

A strong positive correlation $\left(\mathrm{R}^{2}=0.89\right)$ between chloride concentrations and urban land use (fig. 10) and a weak negative relation $\left(\mathrm{R}^{2}=0.42\right)$ between chloride concentrations and mean CC-IBI scores (fig. 11) at the 18 fixed-location sites was determined by using a simple linear regression, which indicates that elevated chloride concentrations are related to benthic-macroinvertebrate assemblage degradation. The correlations are possible predictors of CC-IBI values.

Chloride concentrations can be used as an indicator of human disturbance because human activities and disturbances,

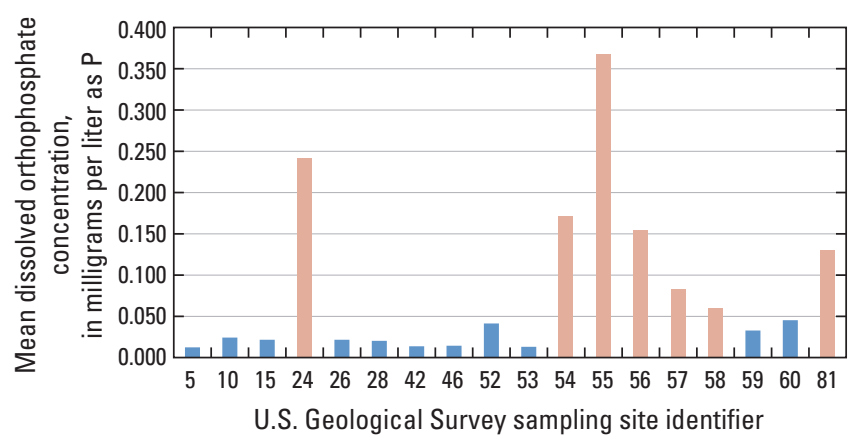

EXPLANATION

No municipal wastewater discharges within 10 miles upstream from site

Municipal wastewater discharge within 10 miles upstream from site

Figure 9. Mean dissolved orthophosphate concentrations in samples collected at 18 fixed-location sites in the Stream Conditions of Chester County Biological Monitoring Network, Chester County, Pennsylvania, 1998-2009.

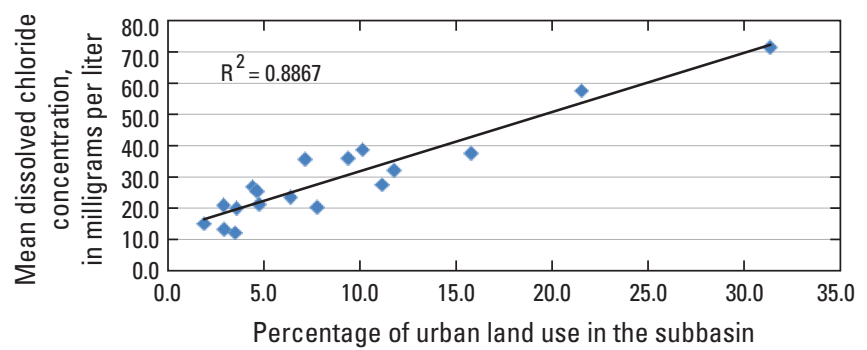

Figure 10. Relation of percentage of urban land use in the subbasins to mean dissolved chloride concentrations for samples collected at 18 fixed-location sites in the Stream Conditions of Chester County Biological Monitoring Network, Chester County, Pennsylvania, 1998-2009.

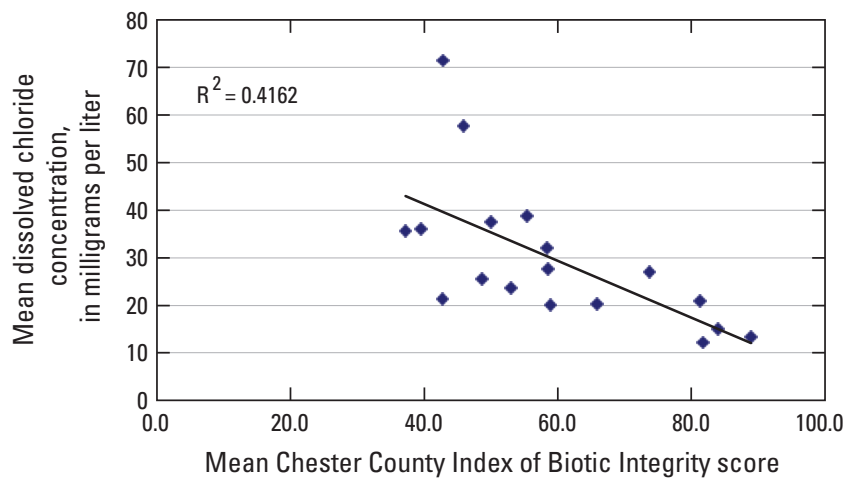

Figure 11. Relation of mean Chester County Index of Biotic Integrity score to mean dissolved chloride concentrations for samples collected at 18 fixed-location sites in the Stream Conditions of Chester County Biological Monitoring Network, Chester County, Pennsylvania, 1998-2009. 
such as agriculture, road salting, point discharges (wastewater and industrial), septic systems, and overland runoff (urban and agricultural), can cause increased chloride concentrations in groundwater and surface waters. Chloride concentrations in base flow have been increasing at biological sampling sites throughout Chester County since measurements began in the 1970s (Senior and Sloto, 2010). The chloride concentrations in samples from Chester County streams are well below the USEPA acute $(860 \mathrm{mg} / \mathrm{L})$ and chronic $(230 \mathrm{mg} / \mathrm{L})$ water-quality criteria and are unlikely to be the direct cause of decreased CC-IBI scores (USEPA, 1986b). Although the chloride concentrations measured in samples collected as part of the Network were less than the USEPA water-quality criteria, it is likely that chloride concentrations exceed the USEPA criteria during road-salt applications in the winter months. Chloride concentrations can increase to more than $10,000 \mathrm{mg} / \mathrm{L}$ during road-salt applications, which can have toxic effects on aquatic organisms (Corsi and others, 2010). Although the benthic-macroinvertebrate sampling occurred during early fall, the organisms collected represent the waterquality conditions that occurred over the full year. Stressors to the aquatic community that occur well before the sampling event (such as road-salt runoff during winter road treatments) have an effect on the organisms collected months later. High concentrations of chloride are also an indication of high urban land use and general human disturbance (Thomas and others, 2007). High amounts of urban land use can lead to alterations in the groundwater-flow patterns as a result of decreased infiltration and increased surface runoff (Paul and Meyer, 2001), which can lead to increased erosion and sedimentation. Urban storm water can increase water temperature and concentrations of nutrients, metals, pesticides, and other organic pollutants (Paul and Meyer, 2001). The increased erosion, sedimentation, and contaminant loads in streams in urban areas can result in decreased diversity of the benthic-macroinvertebrate community (Lenat and Crawford, 1994).

\section{Habitat}

Physical habitat conditions have an effect on the structure and function of the biological communities at a sampling site. Altered physical habitat can be a major stressor for benthic-macroinvertebrate communities and can often obscure the biological response to other stressors (toxicity/chemical contamination). Improvements in water-quality conditions at a sampling site may not result in increased diversity in benthicmacroinvertebrate communities if underlying habitat problems exist. Total habitat scores provide information on the overall habitat quality at a sampling site but do not indicate the cause of any habitat impairment. Two sites with identical habitat scores may have very different habitat impairments. An evaluation of the individual characteristics is needed to determine the habitat features that negatively affect each site.

Habitat scores at the 18 fixed-location sites ranged from 116 at East Branch Chester Creek (site 24, 01476835) to 177 at French Creek (site 15, 01472157; table 13). The mean habitat score at the 84 flexible-location sites sampled from 1998 to 2009 was 147 . The habitat scores at the 84 flexiblelocation sites sampled from 1998 to 2009 ranged from 91 at Beaver Creek (site 78, 01480745) to 176 at Marsh Creek (site 86, 01480675; appendix 4).

On the basis of results from the habitat analysis conducted during the collection of all 320 samples from 1998 to 2009 , sediment erosion and sediment deposition were the major causes of degraded habitat. The characteristics of embeddedness (the amount cobbles and larger-sized fractions are buried in silt, sand, or mud), sediment deposition, and bank stability were scored below the optimal range for more than 70 percent of the 320 site evaluations (fig. 12). Epifaunal substrate (lack of stable or available substrate), vegetative protection, and riparian zone width (disturbed riparian areas) were scored below the optimal range at more than 50 percent of the sites evaluated (table 14). Sediment deposition on the stream bottom reduces the amount and quality of available substrate for benthic macroinvertebrates (Walters, 1995). Disturbed riparian areas can cause an increase in sunlight reaching the stream, which can increase algal growth and water temperatures, resulting in large diel variations in dissolved oxygen levels (Groschen and others, 2000). The combination of heavy erosion, sedimentation, and disturbed riparian areas is common throughout Chester County.

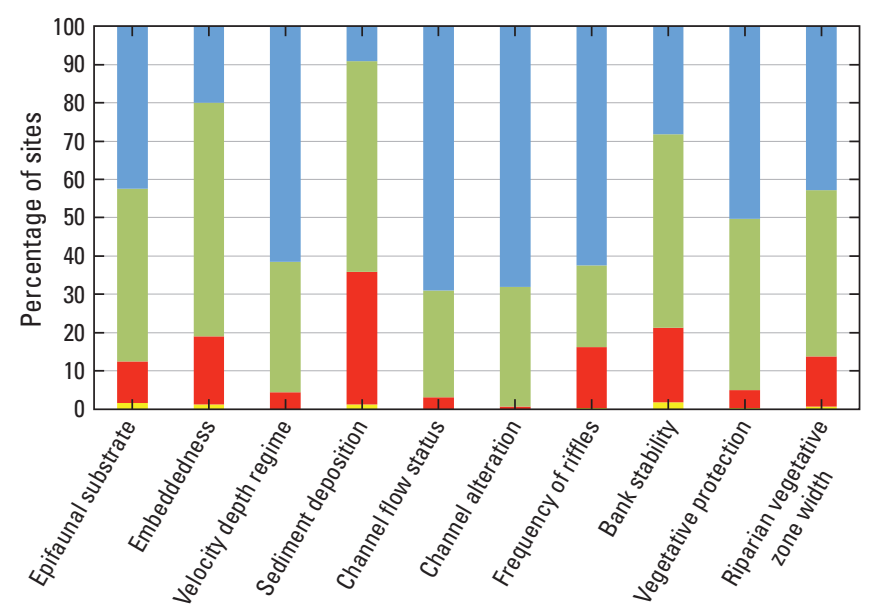

Habitat characteristic

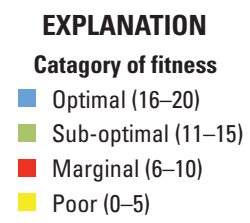

Figure 12. Percentage of sites in 4 categories of 10 habitat characteristics evaluated during collection of 320 benthicmacroinvertebrate samples from sites in the Stream Conditions of Chester County Biological Monitoring Network, Chester County, Pennsylvania, 1998-2009. 

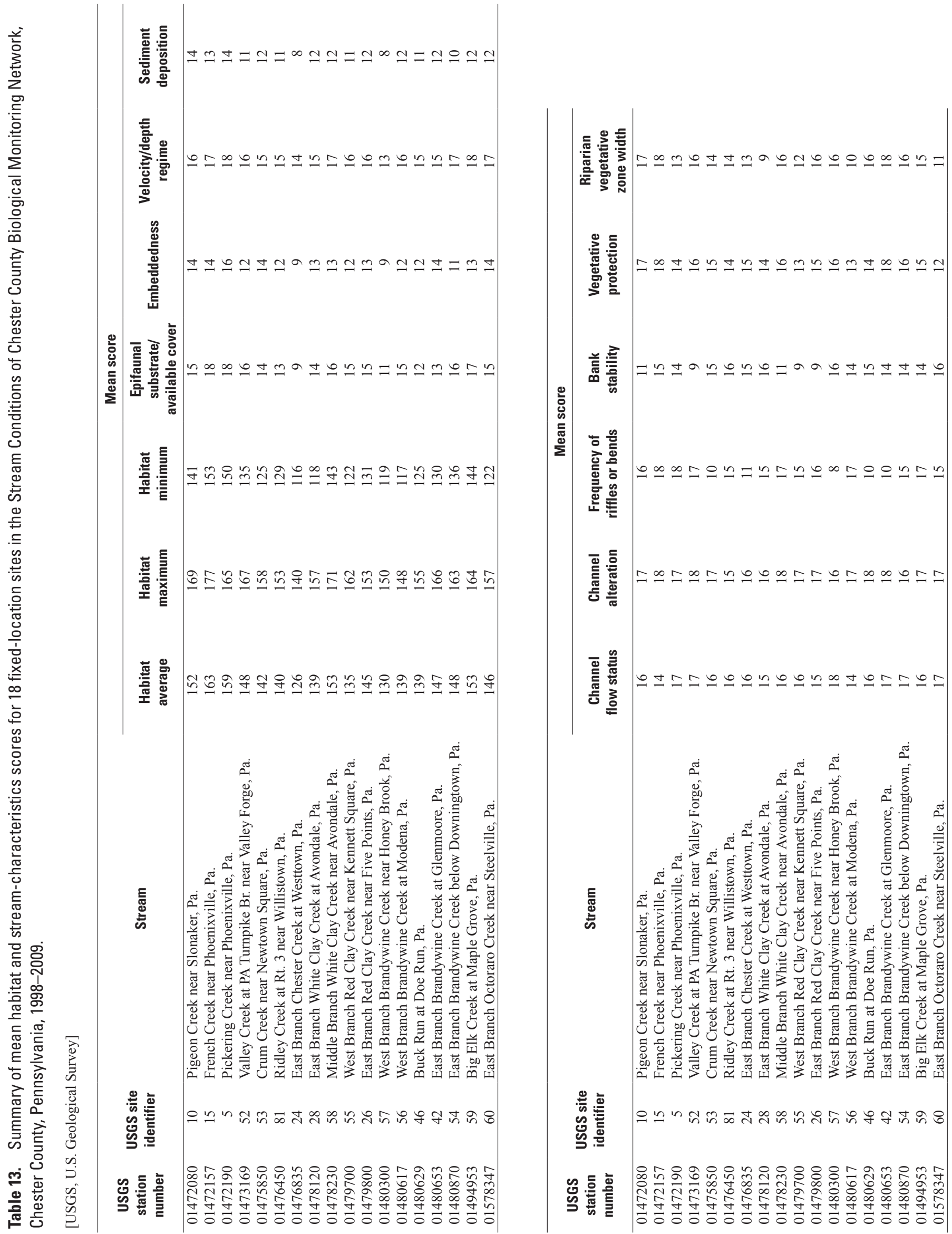


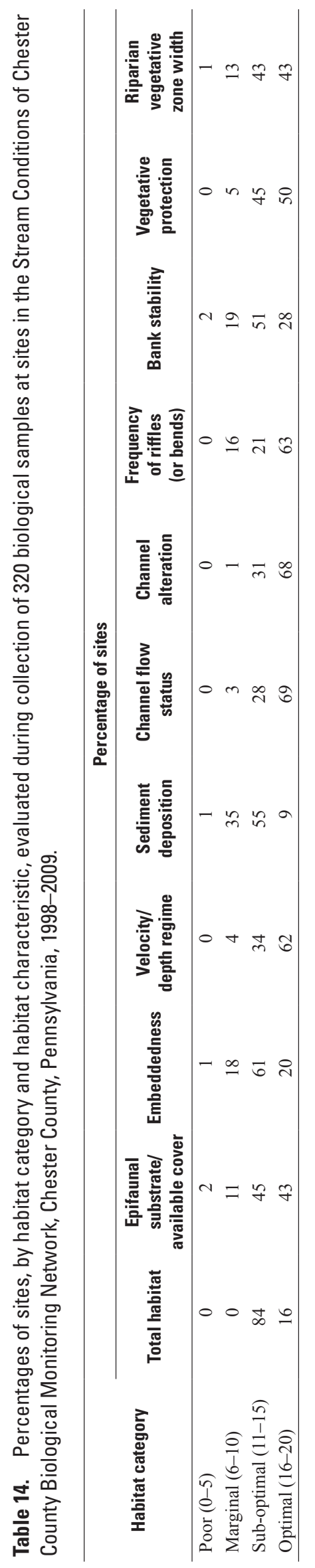




\section{Factors Affecting Chester County Index of Biotic Integrity Scores for 18 Fixed- Location Sites}

Site specific factors such as the water chemistry and physical characteristics, along with subbasin-wide characteristics such as point discharges and land use, affect the overall stream quality that is represented by the final CC-IBI score at a site.

\section{Flow Conditions}

CC-IBI scores from samples collected at the 18 fixedlocation sites indicate a small decrease in benthic-macroinvertebrate diversity at the 18 fixed-location sites during years when extreme high-flow or low-flow conditions preceded the biological sampling. Individual sites had varied responses to the flow conditions, but there was not a Network wide response to extreme high-flow or low-flow conditions.

\section{Nutrients}

Excessive nutrients in an aquatic system can cause increased aquatic plant growth that can alter the physical habitat and water quality, ultimately affecting the benthic-macroinvertebrate community. Diel swings in $\mathrm{pH}$ and dissolved oxygen occur as a result of community respiration. During the sunlight hours, $\mathrm{pH}$ and dissolved oxygen levels will increase as plants produce oxygen and consume carbon dioxide. During the nighttime hours, plant respiration consumes oxygen and produces carbon dioxide resulting in increased $\mathrm{pH}$ values and decreased dissolved oxygen concentrations. Major nutrient sources include non-point sources, such as groundwater discharge (agricultural and septic), overland runoff (agricultural and suburban areas), and point discharges from wastewatertreatment facilities.

Five of the 18 fixed-location sites had a mean orthophosphate concentration greater than $0.10 \mathrm{mg} / \mathrm{L}$, and all had a mean CC-IBI score less than 70 (fig. 13). The mean CC-IBI scores for the five sites ranged from 37 to 58 ; three of the five lowest scoring sites are in this group. In general, plant growth in Chester County streams is limited by the phosphorus concentrations available to the algae and aquatic plants (Paul and Sheng, 2007). Nitrate concentrations in Chester County streams are usually sufficient for plant growth, but a lack of phosphorus limits excessive growth. The addition of phosphorus can trigger excessive plant growth that leads to decreased oxygen levels and degraded habitat.

\section{Wastewater Discharges}

Wastewater discharges provide a direct input of nutrients to a stream, as described above, but they may also provide direct inputs of ions and other compounds. Many of the compounds that may be present in wastewater discharge were not analyzed for, so it is unknown whether they affected the benthic-macroinvertebrate communities in Chester County. The seven sites within 10 miles of upstream wastewater discharge had CC-IBI scores less than 70 and mean orthophosphate concentrations greater than $0.05 \mathrm{mg} / \mathrm{L}$ (fig. 13). From 1998 to 2002, the sampling site on West Branch Red Clay Creek (site 55, 01479700) had a mean nitrate concentration of $4.54 \mathrm{mg} / \mathrm{L}$, a mean phosphorus concentration of 0.721 $\mathrm{mg} / \mathrm{L}$, and a mean CC-IBI score of 29.87. After an upgrade in 2002 at the wastewater-treatment plant that discharges into the West Branch Red Clay Creek the mean nitrate concentration from 2003 to 2009 was $5.90 \mathrm{mg} / \mathrm{L}$, the mean orthophosphate concentration decreased to $0.158 \mathrm{mg} / \mathrm{L}$, and the mean CC-IBI score increased to 46.54 (fig. 14). Improvements in wastewater treatment techniques often result in a decrease in concentrations of ammonia and phosphorus but an increase in nitrate (Mueller and others, 1995).

Boron is a potential wastewater indicator because it is typically present in domestic sewage owing to its use in many household cleaning agents (Senior and Cinotto, 2007). Concentrations greater than $20 \mathrm{mg} / \mathrm{L}$ in Chester County streams are usually associated with municipal wastewater discharges upstream from the sampling location. Samples from six of the seven fixed-location sites that have a municipal wastewater discharge within 10 miles upstream from the sampling site had a mean boron concentration greater than $20 \mu \mathrm{g} / \mathrm{L}$ (fig. 15). Valley Creek (site 52, 01473169) also had mean boron concentrations greater than $20 \mu \mathrm{g} / \mathrm{L}$, but this site is not downstream from a wastewater-treatment discharge. The Valley Creek site is affected by groundwater that contains elevated concentrations of lithium and boron that are related to a former industrial site that used lithium and boron in it processes (Sloto, 1987).

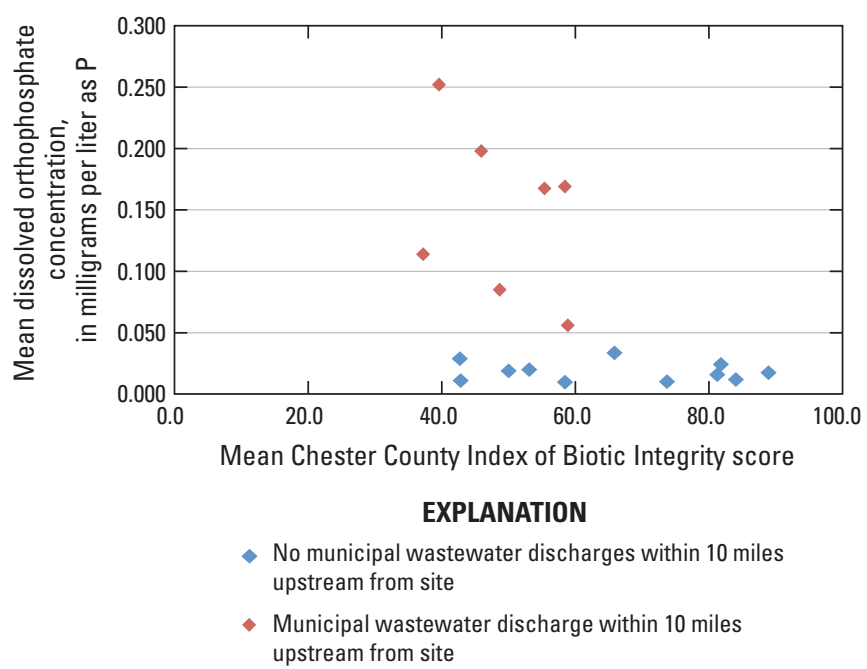

Figure 13. Relation of mean Chester County Index of Biotic Integrity scores to mean dissolved orthophosphate concentration for samples collected at 18 fixed-location sites in the Stream Conditions of Chester County Biological Monitoring Network, Chester County, Pennsylvania, 1998-2009. 


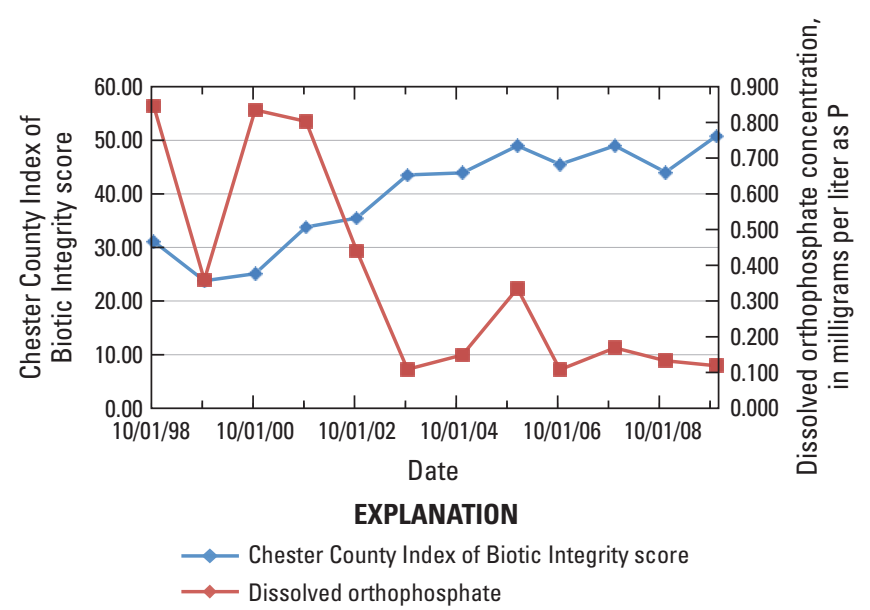

Figure 14. Chester County Index of Biotic Integrity scores and dissolved orthophosphate concentrations for West Branch Red Clay Creek near Kennett Square, Pennsylvania, site 55, 01479700, 1998-2009.

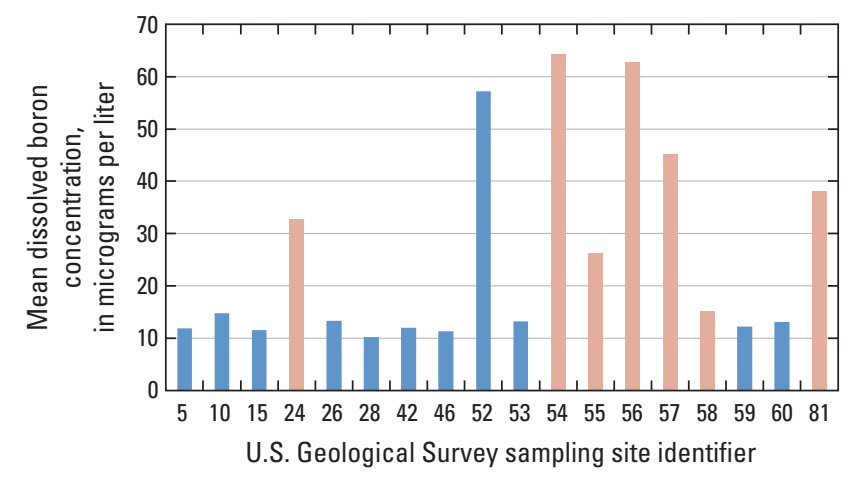

EXPLANATION

No municipal wastewater discharges within 10 miles upstream from site

Municipal wastewater discharge within 10 miles upstream from site

Figure 15. Mean dissolved boron concentrations for 18 fixedlocation sites in the Stream Conditions of Chester County Biological Monitoring Network, Chester County, Pennsylvania, 1998-2009.

\section{Habitat Characteristics}

Instream features and riparian areas have an effect on the biological communities found at a sampling site. Spearman's rank correlation, a non-parametric statistic, was performed on mean CC-IBI and mean habitat characteristics for the 18 fixedlocation sites to identify relations between CC-IBI scores and all habitat characteristics. No strong correlations were identified, but several habitat measures (total RBP habitat score, embeddedness, riparian zone width, vegetative protection, and sediment deposition) had weak correlations with CC-IBI scores. No correlations were identified between CC-IBI score and epifaunal substrate, velocity regime, channel flow status, channel alteration, frequency of riffles, or bank stability. The habitat measures used in the RBP assessment are qualitative measures and are subject to variability owing to the subjective nature of the scoring. The lack of any strong correlations may be due to the qualitative nature of the data. Results of a simple linear regression indicate that mean total RBP habitat scores are positively related $\left(\mathrm{R}^{2}=0.31\right)$ to mean CC-IBI scores at the 18 fixed-location sites (fig. 16). CC-IBI scores were most related to embeddedness $\left(\mathrm{R}^{2}=0.34\right)$, riparian zone width $\left(R^{2}=0.26\right)$, vegetative protection $\left(R^{2}=0.22\right)$, and sediment deposition $\left(\mathrm{R}^{2}=0.17\right)$ (fig. 17). Embeddedness and sediment deposition are both measures of how fine-grained particles affect the streambed. Fine-grained particles on the streambed are unstable, reduce the amount of space available to benthic macroinvertebrates, and can also reduce the gas exchange in the substrate (Waters, 1995). Riparian zone width and vegetative bank protection are out of channel habitat characteristics that affect the instream physical and chemical conditions. A disturbed riparian buffer and deforested stream banks subject the stream to increased sunlight, overland run off, reduced filtration of contaminants, and altered food availability for benthic macroinvertebrates. Increased light reaching the stream increases daytime water temperatures and increases algae growth, which can physically reduce the amount of stable habitat available to benthic macroinvertebrates and lead to decreased oxygen levels. Overland runoff with no filtration of contaminants allows increased flow during rain events that carries contaminants directly to the stream. The increased algae growth and decreased leaf litter in areas without riparian buffers also affect benthic macroinvertebrates by altering their natural food sources, which can have an effect on the community structure.

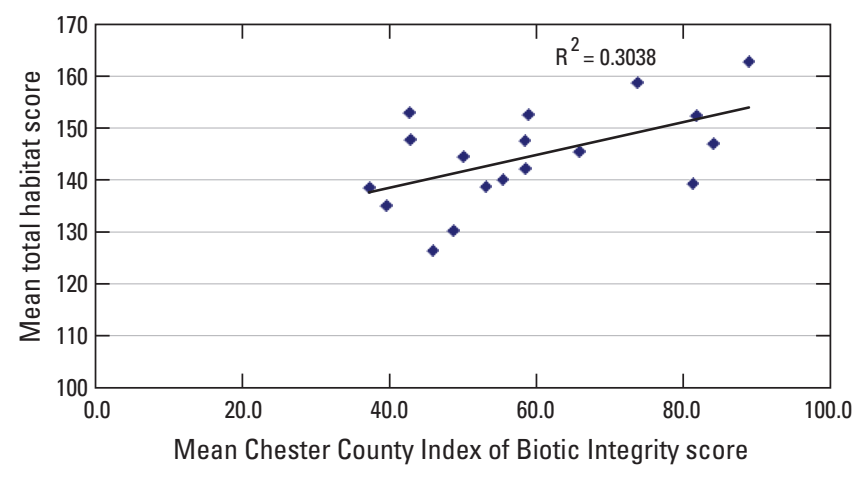

Figure 16. Relation of mean Chester County Index of Biotic Integrity scores to mean total habitat scores for samples collected at 18 fixed-location sites in the Stream Conditions of Chester County Biological Monitoring Network, Chester County, Pennsylvania, 1998-2009. 

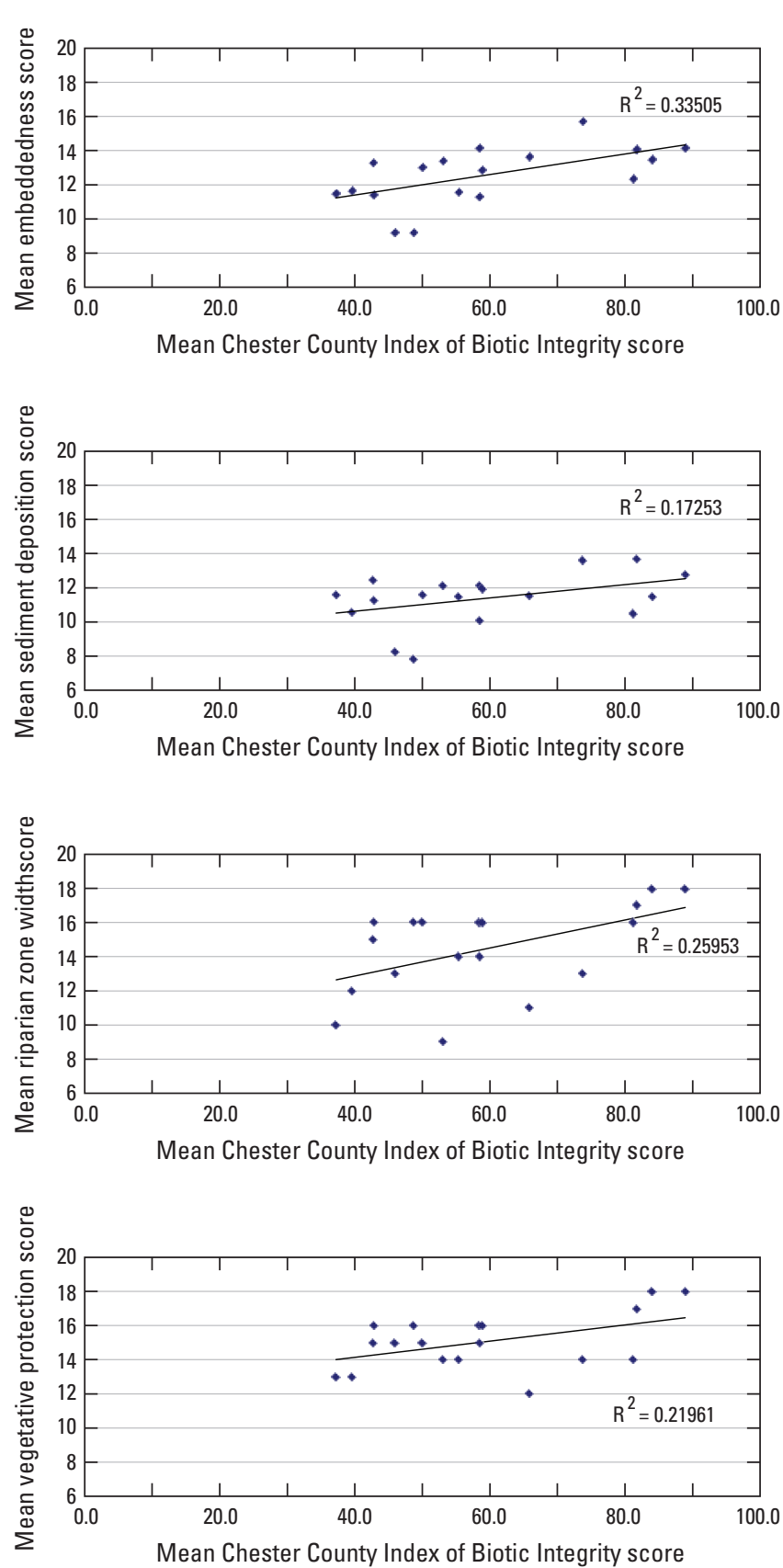

Figure 17. Relation of mean Chester County Index of Biotic Integrity scores to mean embeddedness, mean sediment deposition, mean riparian width, and mean vegetative protection scores for samples collected at 18 fixed-location sites in the Stream Conditions of Chester County Biological Monitoring Network, Chester County, Pennsylvania, 1998-2009.

\section{Land Use}

Land-use practices can affect the physical and chemical conditions at a sampling site, which in turn can affect the biological communities (Couch and Hamilton, 2002). Land use in Chester County is a mix of residential, urban, agricultural, and wooded areas. Because of the varied land use in most subbasins the effects on stream quality are often diverse. In some subbasins, the type of agriculture ranges from hay fields to mushroom houses and includes Amish and modern farming. Land uses were determined for the 18 fixed-location sites (table 15). Land-use statistics were derived from the Delaware Valley Regional Planning Commissions 2005 data set (Delaware Valley Regional Planning Commission, 2005). The land-use categories are residential, urban (commercial, industrial, transportation, and institutional), agricultural (cropland, pasture, orchards, recreation, and nurseries), rangeland (herbaceous vegetation, shrubs, and brush), wooded (deciduous and evergreen), water (streams, lakes, and reservoirs), wetlands (wooded and non-wooded), and barren/ vacant (transitional and mixed areas). Residential land use ranged from 5.2 percent at East Branch White Clay Creek (site 28, 01478120) to 56.2 percent at East Branch Chester Creek (site 24, 01476835). Urban land use ranged from 1.9 percent at East Branch Brandywine Creek (site 42, 01480653) to 31.4 percent at Valley Creek (site 52, 01473169). Agricultural land use ranged from 2.9 percent at Valley Creek (site 52, 01473169) to 66.0 percent at East Branch White Clay Creek (site 28, 01478120). Wooded land use ranged from 8.3 percent at East Branch Chester Creek (site 24, 01476835) to 47.0 percent at French Creek (site 15, 01472157; fig. 3).

Sites with the highest CC-IBI scores generally were located in the north-central and northeast part of Chester County and were associated with subbasins with greater than 28 percent of the area in a combination of wooded, water, and wetland land uses; less than 5 percent in urban land use; and no municipal wastewater discharges within 10 miles upstream (fig. 18). Sites with mean CC-IBI scores less than 50 were associated with sites where urban land use was greater than 15 percent or that had a municipal wastewater discharge within 10 miles upstream from the sampling site (fig. 18). CCIBI scores at the 18 fixed-location sites did not correlate with the percentage of agricultural land use or the percentage of residential land use (fig. 18). Results of the comparisons indicate that the percentage of wooded land use in a subbasin has the greatest positive effect on CC-IBI scores, and the percentage of urban land use has the greatest negative effect on the CC-IBI scores. Results also indicate that wooded and urban land uses are the best land-use predictors of CC-IBI scores. 
Table 15. Summary of land use in the subbasin of 18 fixed-location sites in the Stream Conditions of Chester County Biological Monitoring Network, Chester County, Pennsylvania, 1998-2009.

[USGS, U.S. Geological Survey; $\mathrm{mi}^{2}$, square miles; land use determined from Delaware Valley Regional Planning Commission, 2005]

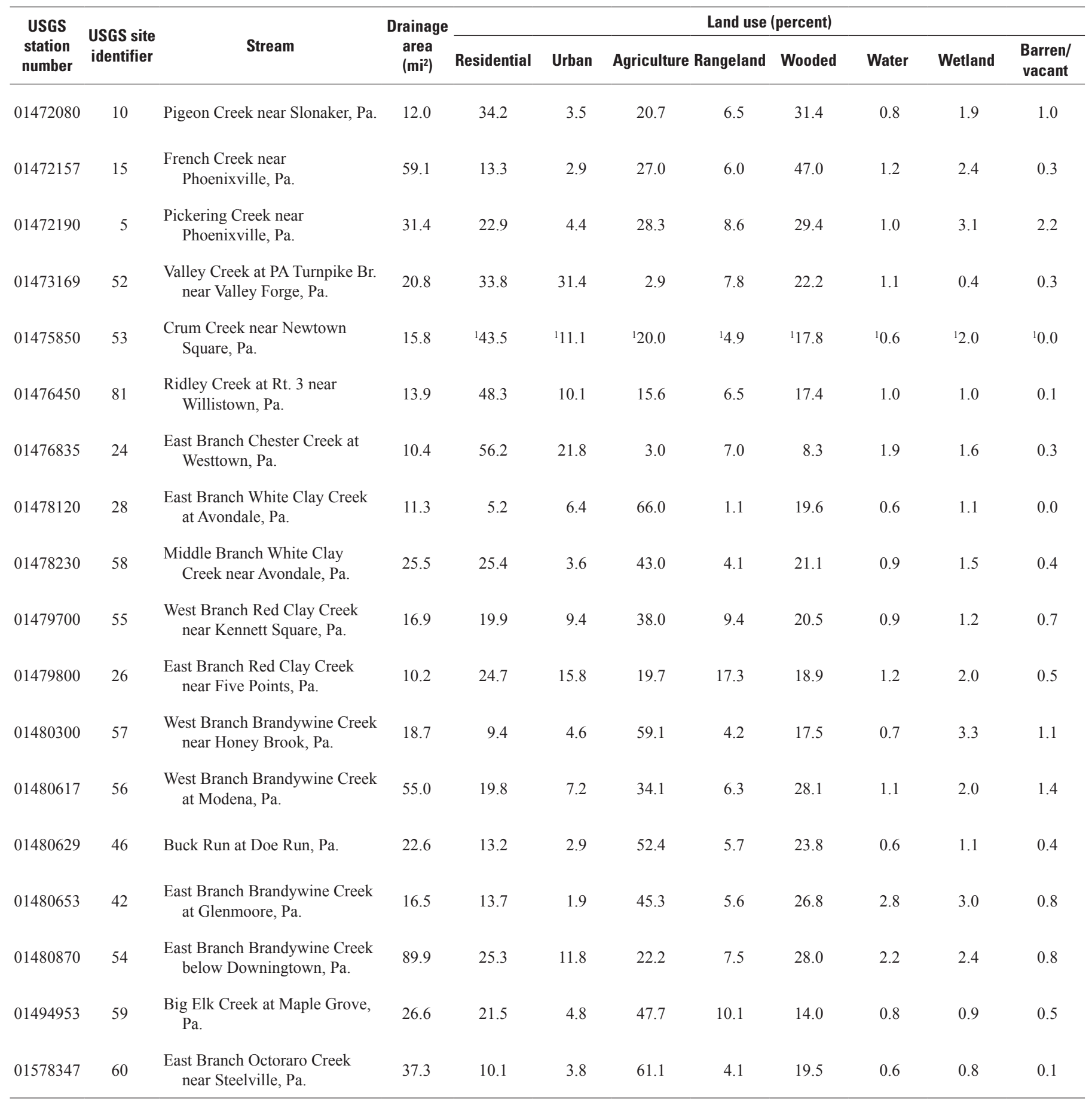

\footnotetext{
${ }^{1}$ Land use for the Delaware County part of Crum Creek was estimated from aerial photos.
} 

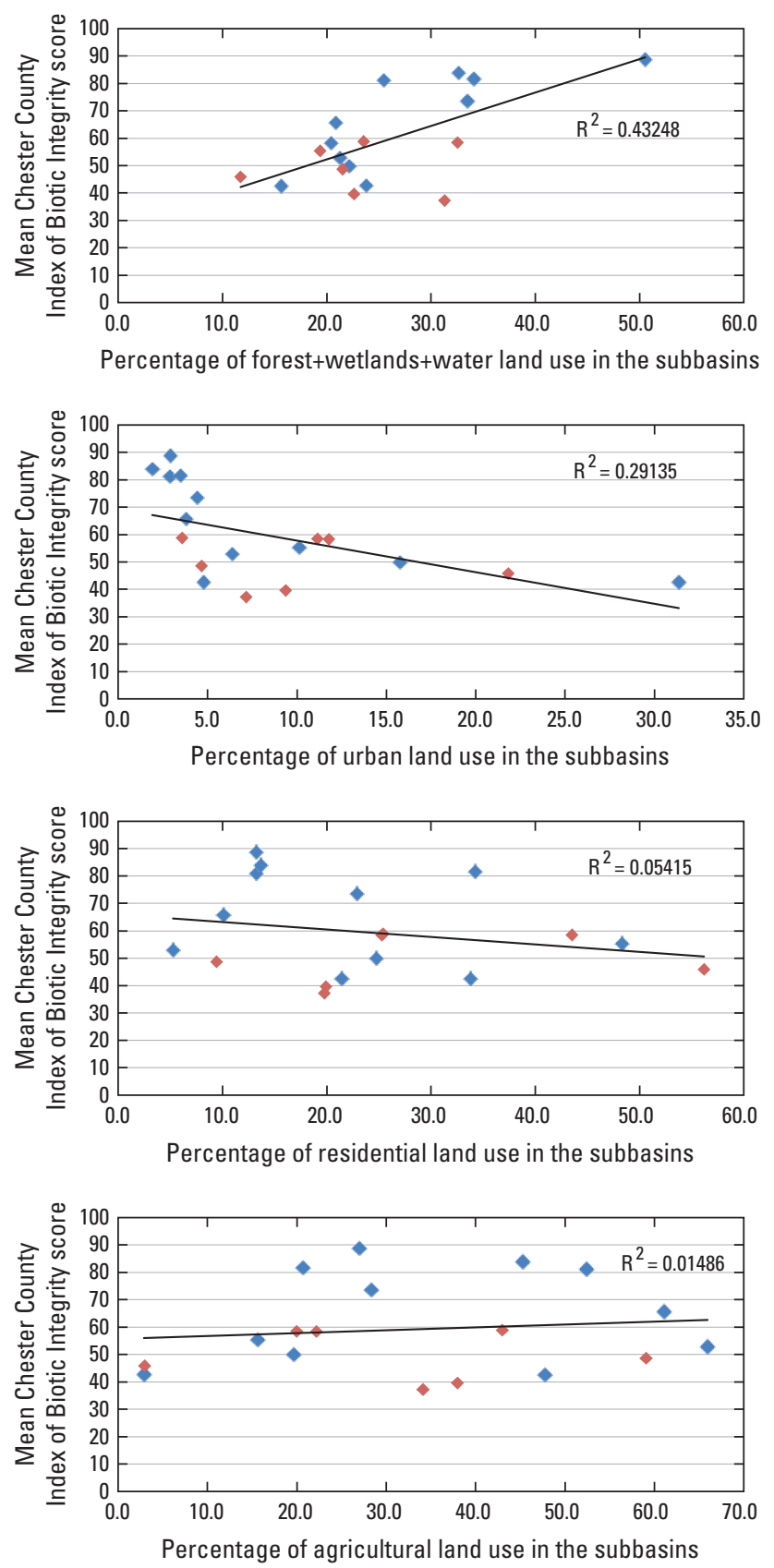

EXPLANATION

- No municipal wastewater discharges within 10 miles upstream from site

- Municipal wastewater discharge within 10 miles unstream from site

Figure 18. Relation of mean Chester County Index of Biotic Integrity scores to percentage of land use for samples from 18 fixed-location sites in the Stream Conditions of Chester County Biological Monitoring Network, Chester County, Pennsylvania, 1998-2009. 


\section{Evaluation of Chester County Index of Biotic Integrity Scores for Selected Flexible-Location Sites}

Data from the 107 samples collected at 84 flexible-location sites from 1998 to 2009 are used to illustrate of the effects of excessive nutrient concentrations, habitat alteration, and land use on benthic-macroinvertebrate communities.

Trout Run (site 82, 01478137), a flexible-location site, had the lowest CC-IBI score (23.48) of all 84 sites from 1998 to 2009. Trout Run is a small headwater stream $\left(1.34 \mathrm{mi}^{2}\right)$ that is a tributary to the East Branch White Clay Creek in the Borough of Avondale (fig 2). Agriculture is the dominant land use in the subbasin ( 31 percent); the subbasin contains numerous mushroom farms. Compost from mushroom farms is a potential source of nutrients and pesticides. Other major land uses in the subbasin are residential (21 percent), wooded (19 percent), and urban (17 percent; table 16). The combination of nitrate $(7.77 \mathrm{mg} / \mathrm{L})$ and orthophosphate $(0.17 \mathrm{mg} / \mathrm{L})$ in a sample from the site is sufficient to cause excessive algal growth (table 17). The habitat assessment score (109) indicates an impairment resulting from sediment-deposition issues. The combination of excessive algal growth and unstable streambed conditions has degraded the benthic-macroinvertebrate community at the site.

Sampling conducted at three sites in the Birch Run subbasin in central Chester County provided an opportunity to evaluate the effect of land use on CC-IBI scores. Birch Run is a small headwater stream $\left(4.6 \mathrm{~m}^{2}\right.$ drainage area) located north of Coatesville within the West Branch Brandywine Creek subbasin. The North Branch Birch Run (site 93, 01480389) subbasin is dominated by wooded land use ( 60 percent) with small amounts of agricultural (11 percent) and urban (4 percent) lands. The South Branch Birch Run (site 92, 01480376) subbasin is dominated by agricultural land use (62 percent) with small amounts of wooded (18 percent) and urban (4 percent) land uses (table 16). On October 22, 2004, sampling was conducted at North Branch Birch Run (site 93, 01480389), South Branch Birch Run (site 92, 01480376), and Birch Run downstream from the confluence of the North and South Branches (site 88, 01480390; fig. 2). All sampling sites were within 500 feet of each other, and samples were collected within 3 hours. The CC-IBI score for the North Branch Birch Run (dominated by wooded land use) was 95.75 , the sixth highest CC-IBI score for the 320 evaluations. The CC-IBI for South Branch Birch Run (dominated by agricultural land use) was 70.37 , and the CC-IBI score for the combined site on Birch Run was 81.78. Chloride, nitrate, and orthophosphate concentrations were lower in the sample from North Branch Birch Run (a primarily wooded subbasin) than in the sample from South Branch Birch Run (a primarily agricultural subbasin; table 17).

Trout Creek subbasin (site 101, 01473210) is heavily urbanized with 44.3 percent residential and 40.2 percent urban land use. Only 5.2 percent of the land is wooded, and no wetlands are present in the subbasin (table 16). This combination of residential and urban land use with little wooded or wetland land use has caused severe erosion and excessive sediment deposition in the subbasin. The site has a CC-IBI score of 33.28 (appendix 3), which indicates a benthic-macroinvertebrate community that is highly degraded compared to reference conditions. Habitat scores indicate that erosion and sediment deposition have resulted in unstable substrate that limits the benthic-macroinvertebrate community.

Indian Run subbasin (site 85, 01480658) has more than 37 percent wooded land use and about 5 percent urban land use (table 16). Nutrient and ion concentrations were among the lowest measured from 1998 and 2009 (appendix 3), and habitat was ranked near the top of all 320 evaluations (table 17). The CC-IBI score for Indian Run was 94.01, which is in the top 3 percent of all samples collected (appendix 2). The combination of a high percentage of wooded land use and low percentage of urban land use results in stable chemical and physical habitats and a diverse benthic-macroinvertebrate community.

Marsh Creek (site 86, 01480675) had the highest CC-IBI score (99.96) of all 320 samples collected (appendix 2). Marsh Creek had land use and chemical conditions similar to those at the Indian Run site, but the Marsh Creek subbasin also had 8.6 percent wetlands land use (table 16). This large amount of wetlands, along with 37 percent wooded land use and less than 1 percent urban land use, created stable chemical and physical habitat conditions that supported the most diverse benthic-macroinvertebrate community in Chester County (table 16).

\section{Trends in Chester County Index of Biotic Integrity Scores and Selected Chemical Constituent Concentrations}

Benthic macroinvertebrates are found in nature in a nonrandom distribution as a result of the habitat and behavior requirements of individual organisms (Greeson and others, 1977). Nonparametric statistical methods are typically used for the detection of trends in water-quality data because of the problems of skewness (data that are not symmetrically distributed on both sides of the mean) and serial correlation (the correlation of a value with itself) (Hirsch and others, 1982). The Mann Kendall test for trends, a nonparametric test for monotonic trends over time, was used to detect trends in CCIBI scores and concentrations of nitrate, orthophosphate, and chloride at the 18 fixed-location sites. Nitrate, orthophosphate, and chloride were tested for correlations with flow at each individual site. The Mann Kendall test for trends was run without flow adjustments for sites where constituents were not found to be related to flow $\left(\mathrm{R}^{2}<0.75\right)$ and with flow adjustments at sites where constituents were related to flow $\left(\mathrm{R}^{2}>0.75\right)$. Trends at Ridley Creek (site 81, 01476450) were estimated using the Annual Kendall test for trends because the site had less than the required number of samples needed for the Mann Kendall test. The results of the trend tests are presented in table 18. Trends are considered significant at a 90-percent confidence level $(\mathrm{p}<0.10)$. 

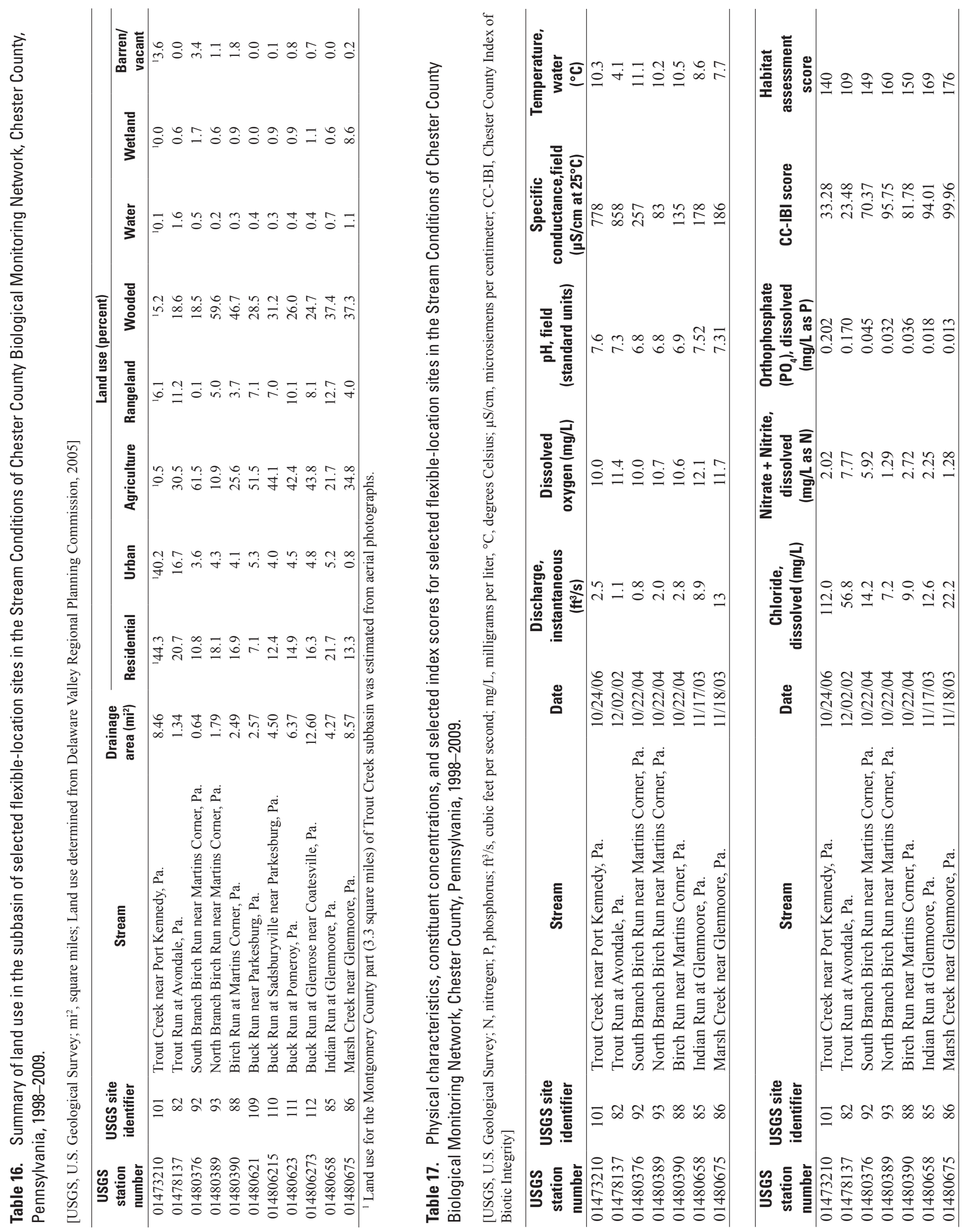


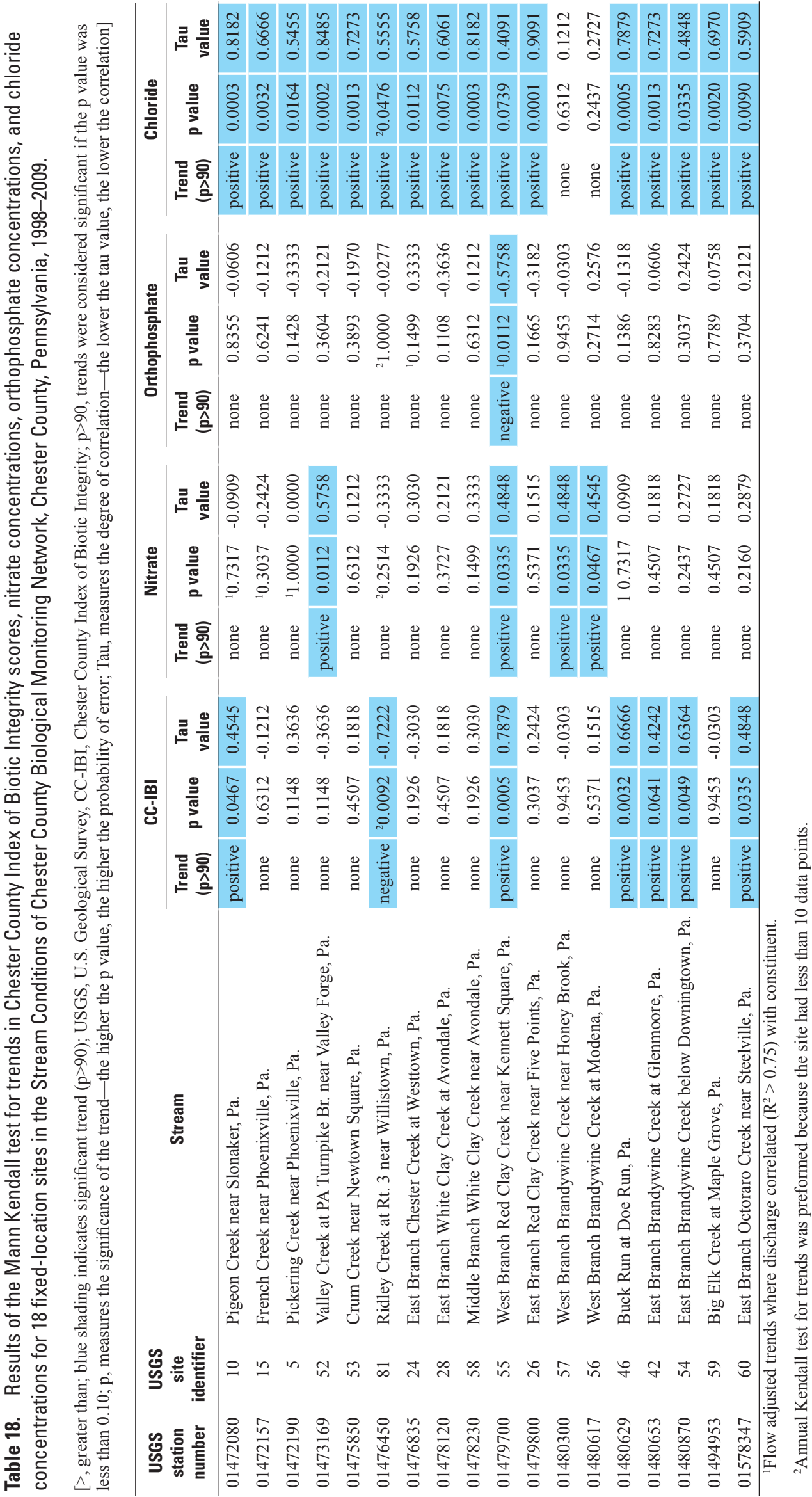


Trends were detected in CC-IBI scores for 7 of the 18 fixed-location sites. Six sites had increasing CC-IBI scores, indicating improving conditions, and one site, Ridley Creek (site 81,01476450), had a negative trend, indicating degrading biological conditions. The six sites with positive trends in CCIBI scores are Pigeon Creek (site 10, 01472080), West Branch Red Clay Creek (site 55, 01479700), Buck Run (site 46, 01480629), East Branch Brandywine Creek (site 42, 01480653 and site 54, 01480870), and East Branch Octoraro Creek (site 60, 01578347). The CC-IBI scores for all 18 sites are plotted by stream subbasin and presented in figures 19 to 23 . The increase in CC-IBI scores at six sites cannot be easily related to a single direct cause but may be related to watershed management efforts, including implementation of agricultural best management practices, stream restoration, storm water management, and public education, along with decreased discharges from industrial operations. However, the positive CC-IBI trend at the West Branch Red Clay site is most likely related to the significant decrease in dissolved orthophosphate concentrations, following an upgrade to the wastewater-treatment plant in 2002 (fig. 14).

Positive trends were detected in dissolved nitrate concentrations at 4 of the 18 fixed-location sites. The sites with positive trends in dissolved nitrate concentrations were Valley Creek (site 52, 01473169), West Branch Red Clay Creek (site 55, 01479700), and the West Branch Brandywine sites (57, 01480300 and 56, 01480617). The West Branch Red Clay Creek (site 55, 01479700) had a negative trend in dissolved orthophosphate concentrations. No other sites had a significant trend in orthophosphate concentrations. The trends at the West Branch Red Clay and West Branch Brandywine sites may be related to wastewater-treatment discharge upstream from the site and from agricultural land use in the watershed.

Positive trends in dissolved chloride concentrations were found for 16 of the 18 fixed-location sites. No trends in dissolved chloride concentrations were found for the West Branch Brandywine sites (57, 01480300 and 56, 01480617). Both of these sites were affected by wastewater discharges which may be the major factor controlling the dissolved chloride concentrations. Increased dissolved chloride concentrations across Chester County are most likely associated with increased urbanization and human activities, such as agriculture, road salting, point discharges (wastewater and industrial), septic systems, and overland runoff (urban and agricultural). The increased chloride concentrations in urban and agricultural areas in Chester County are similar to results reported by Mullaney and others (2009) and Heisig (2000).
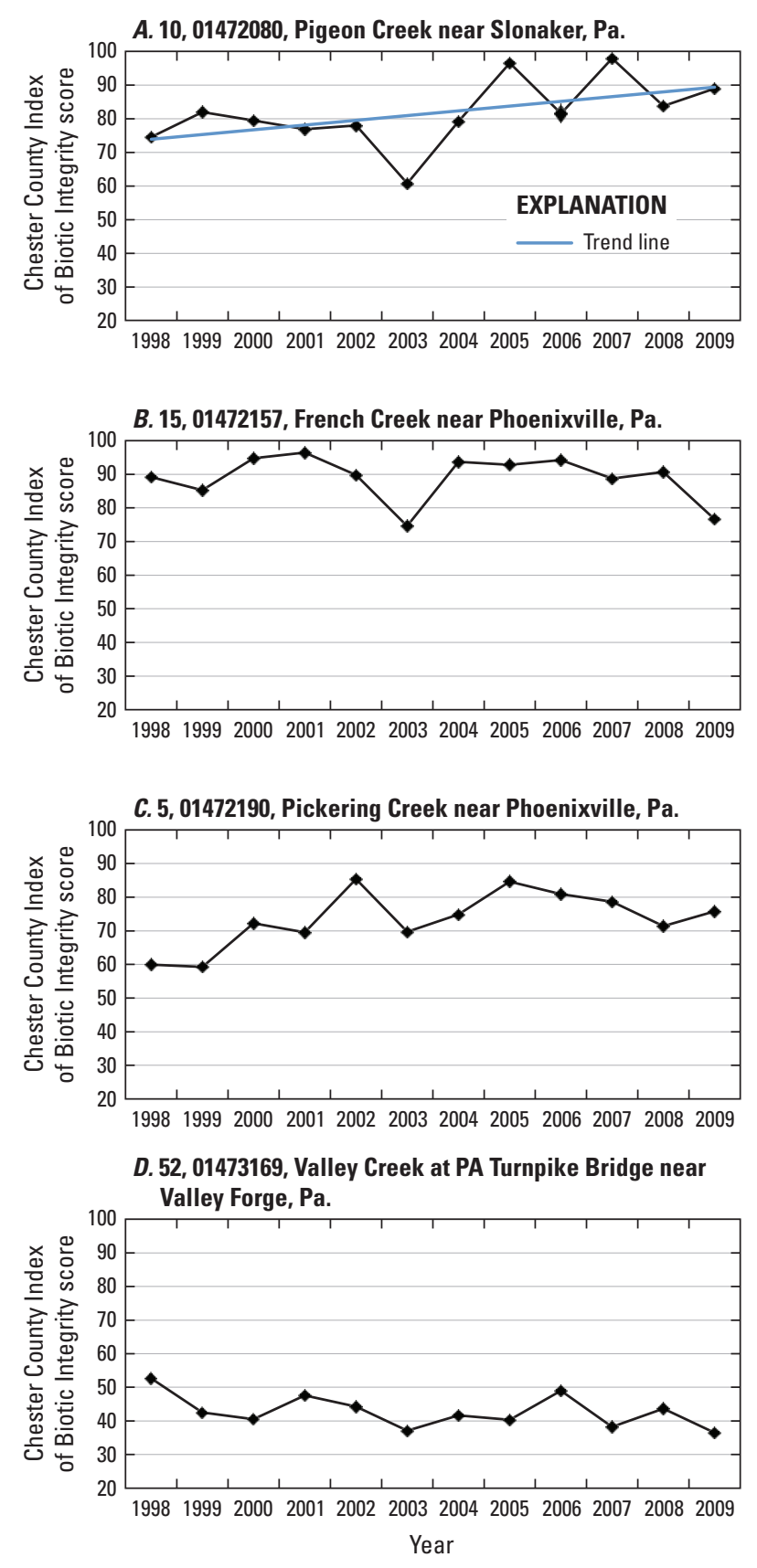

Figure 19. Chester County Index of Biotic Integrity scores for fixed-location sites in the Schuylkill River Basin, Pennsylvania, 1998-2009: $A$, site 10, 01472080, Pigeon Creek at Slonaker, Pa.; $B$, site 15, 01472157, French Creek near Phoenixville, $P a$.; $C$, site 5 , 01472190, Pickering Creek near Phoenixville, Pa.; and $D$, site 52, 01473169, Valley Creek at PA Turnpike Bridge near Valley Forge, $\mathrm{Pa}$. (Trend line added if the Mann Kendall test for trend indicated a significant trend ( $p$ value less than 0.10 ).) 

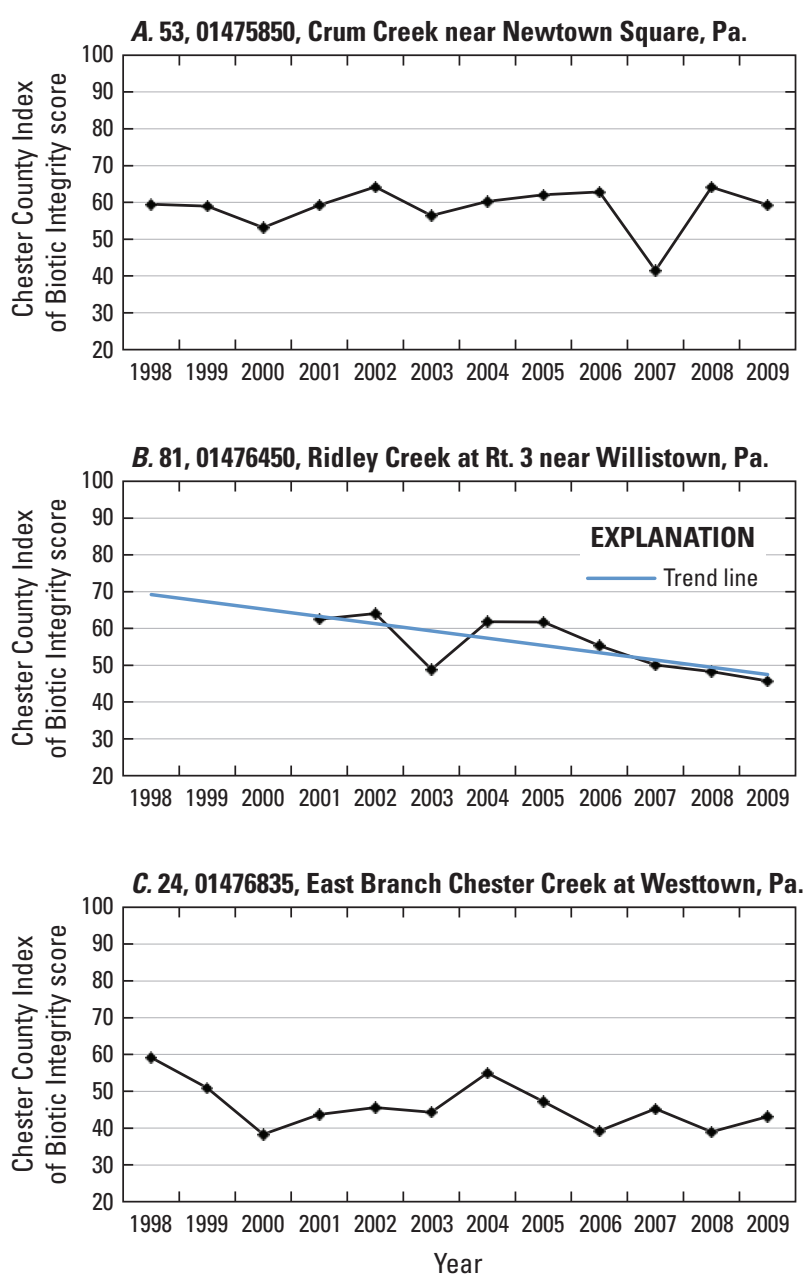

Figure 20. Chester County Index of Biotic Integrity scores for fixed-location sites in the Delaware River Basin, Pennsylvania, 1998-2009: $A$, site 53, 01475850, Crum Creek near Newtown Square, Pa.; $B$, site 81, 01476450, Ridley Creek at Rt. 3 near Willistown, Pa., 2001-2009; and C, site 24, 01476835, East Branch Chester Creek at Westtown, Pa., 1998-2009. (Trend line added if the Mann Kendall test for trend indicated a significant trend ( $p$ value less than 0.10$)$.)
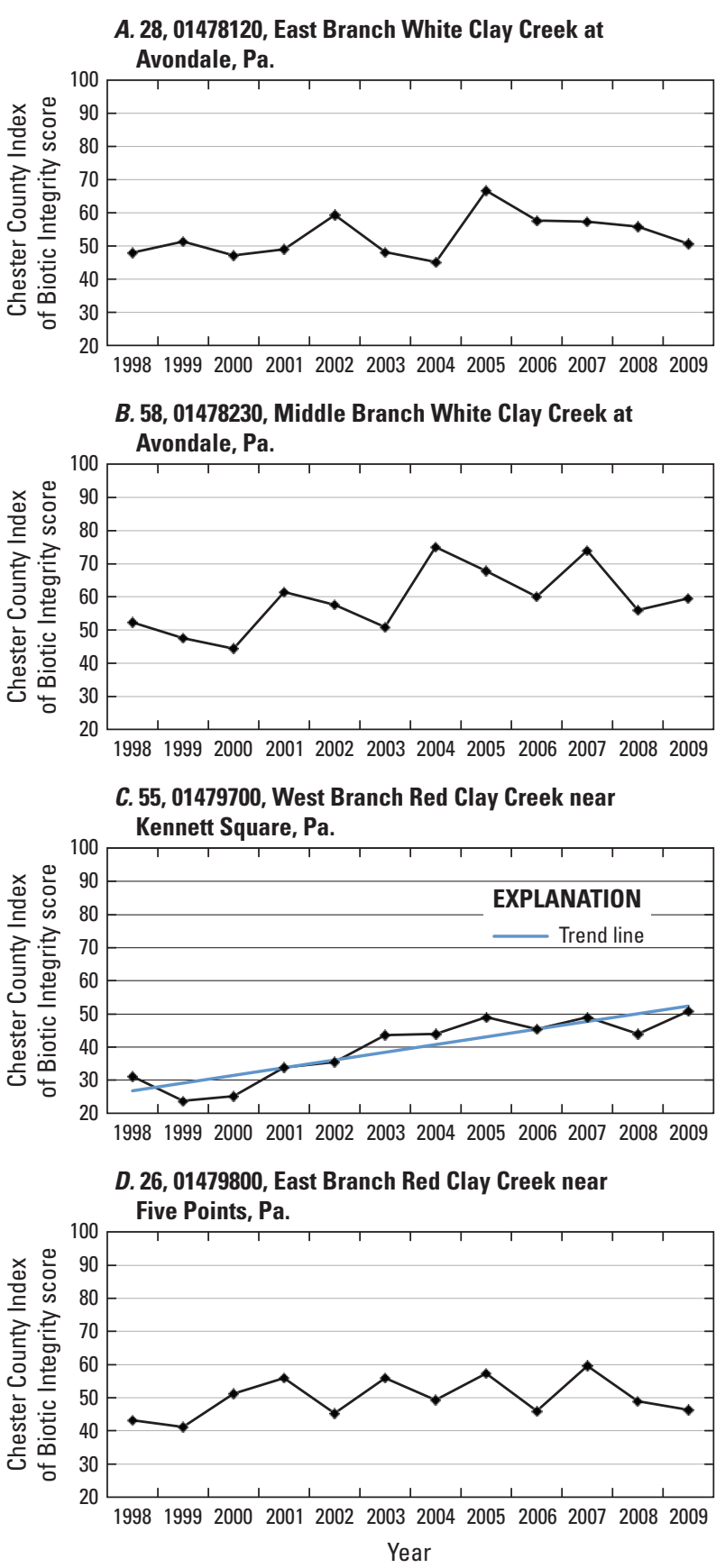

Figure 21. Chester County Index of Biotic Integrity scores for fixed-location sites in the Red Clay and White Clay Creek Basins: $A$, site 28, 01478120, East Branch White Clay Creek at Avondale, Pa.; $B$, site 58, 01478230, Middle Branch White Clay Creek near Avondale, Pa.; $C$, site 55, 01479700, West Branch Red Clay Creek near Kennett Square, $\mathrm{Pa}$.; and D, site 26, 01479800, East Branch Red Clay Creek near Five Points, Pa., 1998-2009. (Trend line added if the Mann Kendall test for trend indicated a significant trend ( $p$ value less than 0.10$)$.) 

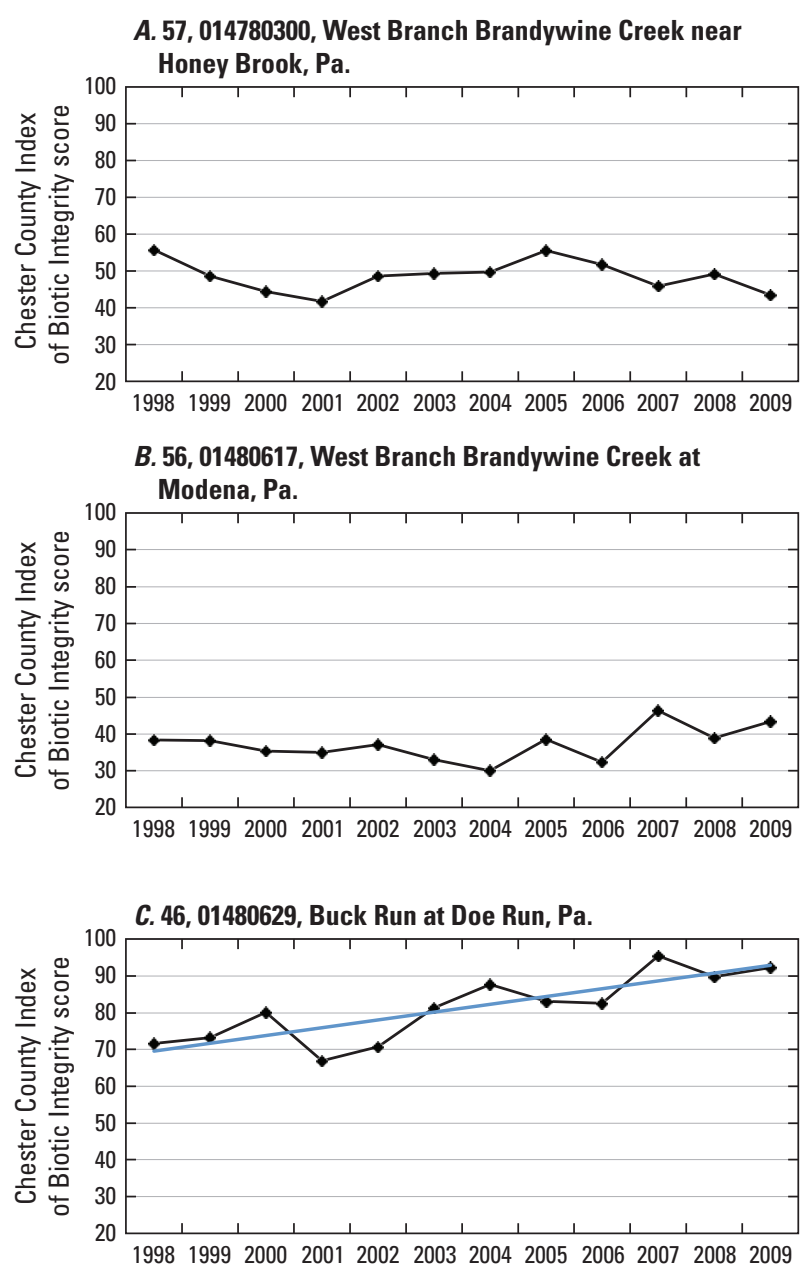
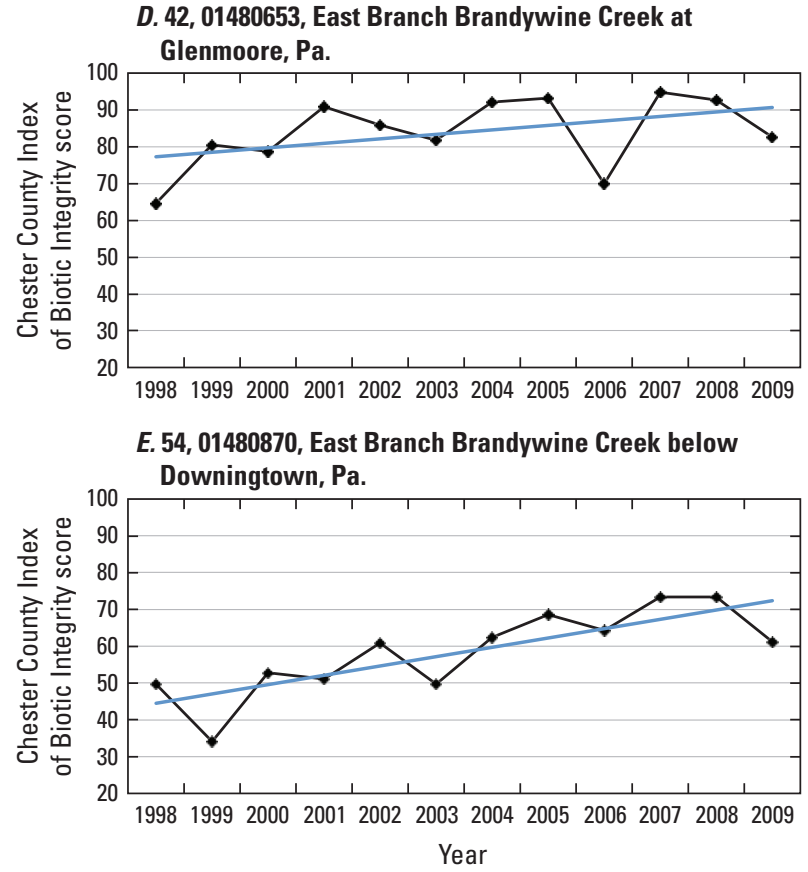

EXPLANATION

— Trend line

Figure 22. Chester County Index of Biotic Integrity scores for fixed-location sites in the Brandywine River Basin, 1998-2009: A, site 57, 01480300, West Branch Brandywine Creek near Honey Brook, Pa.; B, site 56, 01480617, West Branch Brandywine Creek at Modena, Pa.; C, site 46, 01480629, Buck Run at Doe Run, Pa.; D, site 42, 01480653, East Branch Brandywine Creek at Glenmoore, Pa.; and E, site 54, 01480870, East Branch Brandywine Creek below Downingtown, $\mathrm{Pa}$. (Trend line added if the Mann Kendall test for trend indicated a significant trend ( $p$ value less than 0.10$)$.)

A. 59, 01494953, Big Elk Creek at Maple Grove, Pa.

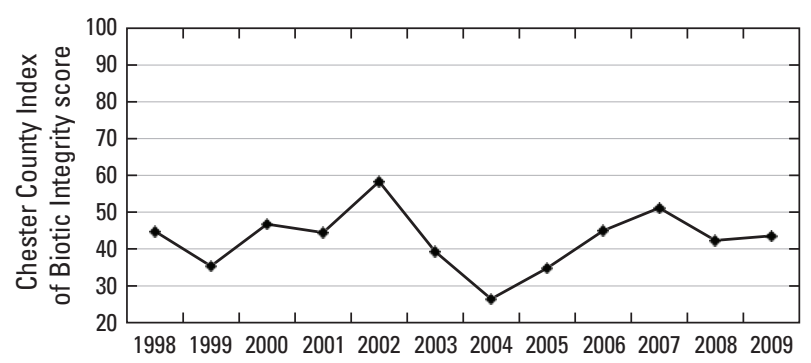

B. 60, 01578347, East Branch Octoraro Creek near

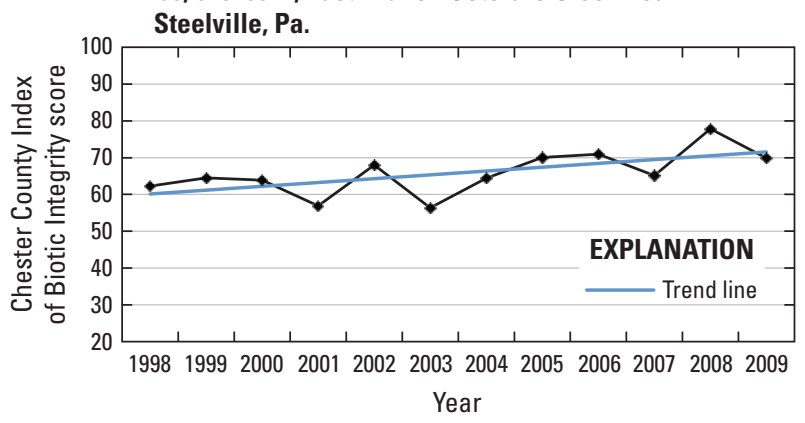

Figure 23. Chester County Index of Biotic Integrity scores for fixed-location sites in the Susquehanna River and Chesapeake Bay Basins, 1998-2009: $A$, site 59, 01494953, Big Elk Creek at Maple Grove, Pa.; and B, site 60, 01578347, East Branch Octoraro Creek near Steelville, Pa. (Trend line added if the Mann Kendall test for trend indicated a significant trend ( $p$ value less than 0.10 ).) 


\section{Summary and Conclusions}

The Stream Conditions of Chester County Biological Monitoring Network (Network) was established by the U.S. Geological Survey (USGS) and the Chester County Water Resources Authority in 1969 as a means of assessing the quality of Chester County streams using benthic-macroinvertebrate data. Chester County covers $760 \mathrm{mi}^{2}$ in southeastern Pennsylvania and has a rapidly expanding population. The county nearly doubled in population from 1960 to 1995 and had a 15-percent increase in population from 2000 to 2009. Substantial land-use change has occurred in response to this continual growth, as open space and agricultural land have been converted to residential and commercial lands. In 2000, about 39 percent of the land was agricultural; 31 percent, woodedrangeland-water; 17 percent, residential; and 13 percent urban or barren, which includes transportation and parking.

In 1998, the biological network was re-configured to include 18 fixed-location sites and 9 flexible-location sites. The 18 sites were sampled annually in the fall (OctoberNovember) during base-flow conditions for water chemistry, instream habitat, and benthic macroinvertebrates. The 18 fixed-location sites included 5 sites from the original network (1969-1997) and 13 new sites, of which 6 were existing USGS streamgaging stations so that flow and water-quality data could be used in relation to the biological data. From 1998 to 2009, 213 samples were collected from the 18 fixedlocation sites. The remaining nine sites were selected annually and were used to expand the coverage of sampled streams and for detailed reconnaissance sampling in individual subbasins. A new set of nine flexible-location sites was selected each year. From 1998 to 2009, 107 samples were collected from 84 flexible-location sites.

Benthic-macroinvertebrate data from samples collected from 1998 to 2009 were used to establish the Chester County Index of Biotic Integrity (CC-IBI). The CC-IBI was developed using the methods and metrics outlined in The Pennsylvania Department of Environmental Protection's “A Benthic Index of Biotic Integrity for Wadeable Freestone Streams in Pennsylvania (Pa-IBI)." Because of the differences in sampling and sorting techniques, and metric reference values, the scores produced by the CC-IBI and the Pa-IBI are not directly comparable. The CC-IBI consist of six metrics to calculate the final CC-IBI scores - total taxa richness, Ephemeroptera (mayflies), Plecoptera (stoneflies), and Trichoptera (caddisflies), taxa richness, Hilsenhoff Biotic Index, Beck's Index, Shannon Diversity, and percent sensitivity. The resulting CC-IBI scores rate benthic-macroinvertebrate samples collected from sites in the Network in relation to reference conditions found in Chester County. Scores can range from 0 to 100 with scores near 100 representing conditions similar to the reference condition.

The 18 fixed-location sites sampled had mean CC-IBI scores ranging from 37.21 at the West Branch Brandywine at Modena (site 56, 01480617) to 88.92 at French Creek (site 15, 01472157). Thirty-nine percent of the 213 samples collected at the 18 fixed-location sites had a CC-IBI score less than 50,
33 percent scored from 50 to 70 , and 28 percent scored greater than 70. CC-IBI scores for the 107 flexible-location sites ranged from 23.48 at Trout Run (Site 82, 01478137) to 99.96 at Marsh Creek (site 86, 01480675) with a mean score of 63.57 (appendix 2). Twenty-five percent of the 107 samples collected at the flexible-location sites had a CC-IBI score less than 50, 33 percent scored from 50 to 70 , and 42 percent scored greater than 70 .

Factors that were found to affect CC-IBI scores are nutrient concentrations, habitat conditions, and percentage of wooded and urban land use. Excess nutrients in the aquatic system can cause increased aquatic plant growth that can alter the physical habitat and water quality, leading to changes in the $\mathrm{pH}$, water temperature, and dissolved oxygen levels, which can cause a change in the benthic-macroinvertebrate community. Five of the 18 fixed-location sites had a mean orthophosphate concentration greater than the U.S. Environmental Protection Agency's recommended concentration of $0.10 \mathrm{mg} / \mathrm{L}$. These five sites had CC-IBI scores less than 70; two of the five sites had CC-IBI scores less than 40 (West Branch Brandywine Creek-site 56, 01480617 and West Branch Red Clay Creek-site 55, 01479700). All five sites were located within 10 miles of an upstream municipal wastewater-discharge site.

The physical habitat of instream features and riparian areas has an effect on the biological communities. A relation was determined between mean CC-IBI scores and mean total habitat scores for the 18 fixed-location sites. CC- IBI scores were weakly related to vegetative protection, embeddedness, riparian zone width, and sediment deposition. Embeddedness and sediment deposition are measurements of the amount of silt and sand deposited on the streambed. Fine-grained particles on the streambed are unstable, reduce the amount of stable habitat available to aquatic organisms, and can reduce benthic-macroinvertebrate diversity. Riparian zone width and vegetative bank protection are out of channel habitat measurements that affect the physical and chemical conditions of the stream. A disturbed riparian buffer and bare stream banks subject the stream to increased sunlight, overland run off, reduced filtration of contaminants, and altered food availability for benthic macroinvertebrates. An increase in the light getting to a stream increases daytime water temperatures and increases algal growth, which can lead to decreased oxygen levels and can physically reduce the amount of stable habitat available to benthic macroinvertebrates.

Land-use practices can affect the physical and chemical conditions at a sampling site which in turn can affect the biological communities. Sites with the highest CC-IBI scores generally were located in the north-central and northeast part of Chester County and were associated with areas that had greater than 28 percent wooded-wetland-water land use, less than 5 percent urban land use, and no wastewater discharges within 10 miles upstream from the sampling site. Sites with the lowest CC-IBI scores were spread through Chester County but generally were associated with areas where urban land use was greater than 15 percent or a municipal wastewater discharge was present within 10 miles upstream from the 
sampling site. CC-IBI scores for the 18 fixed-location sites were not correlated with the percentage of agricultural or residential land use, indicating that increasing percentage of wooded land use in a subbasin has the greatest positive effect on CC-IBI scores, and increasing percentage of urban land use has the greatest negative effect on the CC-IBI scores.

The Mann Kendall test was used to determine trends in CC-IBI scores and trends in concentrations of nitrate, orthophosphate, and chloride at the 18 fixed-location sites. A positive trend in CC-IBI scores was found for six sites, and a negative trend was found for 1 site. Positive trends were determined for nitrate concentrations for 4 of the 18 sites. One site had a negative trend in orthophosphate concentrations. Positive trends in chloride concentrations were determined for 16 of the 18 fixed-location sites. The positive trends in CC-IBI scores and constituent concentrations could not be easily related to a single direct cause, but they may be related to watershed management efforts, including implementation of agricultural best management practices, stream restorations, improved storm water management, and public education, along with the improved quality of discharges from industrial and wastewater-treatment facilities. The positive trends in chloride concentrations could be attributed to increased urbanization.

\section{References Cited}

Barbour, M.T., Stribling J.B., and Karr, J.R., 1995, Multimetric approach for establishing biocritera and measuring biological condition, in Davis, W.S., and Simon, T.P., eds., Biological assessment and criteria: tools for water resource planning and decision making: CRC Press, Boca Raton, Florida, p. 63-77.

Barbour, M.T., Gerritsen, J., Snyder, B.D., and Stribling, J.B., 1999, Rapid bioassessment protocols for use in streams and wadeable rivers: Periphyton, Benthic Macroinvertebrates and Fish (2d ed.): Washington, D.C., U.S. Environmental Protection Agency, Office of Water, EPA/841B-99-002.

Beck, W.H., Jr., 1955, Suggested method for reporting biotic data: Sewage and Industrial Waste, v. 27, no. 10, p. 1193-1197.

Bode, R.W., Novak, M.A., Abele, L.W., Heitzman, D.L., and Smith, A.J., 2002, Quality assurance work plan for biological stream monitoring in New York State: New York State Department of Environmental Conservation, 115 p.

Chalfant, B., 2007, A Benthic Index of Biotic Integrity for Wadeable Freestone Streams in Pennsylvania: Pennsylvania Department of Environmental Protection, 157 p.

Chester County, 1996, Landscapes-Managing change in Chester County, 1996-2020, Comprehensive plan policy element: West Chester, Chester County, Pa., 128 p.
Cinotto, P.J., Reif, A.G., Olson, L.E., 2005, Environmental setting, water budget, and stream assessment for the Broad Run watershed, Chester County, Pennsylvania: U.S. Geological Survey Scientific Investigations Report 2005-5156, $59 \mathrm{p}$.

Corsi, S.R., Graczyk, D.J., Geis, S.W., Booth, N.L., and Richards, K.D., 2010, A fresh look at road salt: aquatic toxicity and water-quality impacts on local, regional, and national scales: Environmental Science and Technology, v. 44, no. 19 , p. $7376-7382$.

Couch, Carol, and Hamilton, Pixie, 2002, Effects of urbanization on stream ecosystems: U.S. Geological Survey Fact Sheet $042-02,2 \mathrm{p}$.

Courtemanche, D.L., 1996, Commentary on the subsampling procedures used for rapid bioassessments: Journal of the North American Benthological Society, v. 15, p. 381-385.

Delaware Valley Regional Planning Commission, 2004, 2000 land use by minor civil division, Regional data bulletin \#78, March 2004: Philadelphia, Pa., Delaware Valley Regional Planning Commission.

Delaware Valley Regional Planning Commission, 2005, Land Use Data Set: Philadelphia, Pa., Delaware Valley Regional Planning Commission.

Delaware Valley Regional Planning Commission, 2007, Delaware Valley Data-Analytical data report (Number 14) -Regional, county, and municipal population and employment forecast, 2005-2035: Philadelphia, Pa., Delaware Valley Regional Planning Commission.

Fishman, M.J., and Friedman, L.C., 1989, Methods for determination of inorganic substances in water and fluvial sediments: U.S. Geological Survey Techniques of WaterResources Investigations, book 5, chap. A1, 545 p.

Greeson, P.E., Ehlke, T.A., Irwin, G.A., Lium, B.W., and Slack, K.V., 1977, Methods for the collection and analysis of aquatic biological and microbiological samples: U.S. Geological Survey Techniques of Water-Resources Investigations, book 5, chap. A4, $332 \mathrm{p}$.

Groschen, G.E., Harris, M.A., King, R.B., Terrio, P.J. and Warner, K.L., 2000, Water quality in the lower Illinois River Basin, Illinois, 1995-1998: U.S. Geological Survey Circular $1209,36 \mathrm{p}$.

Hardy, M.A., Wetzel, K.L., and Moore, C.R., 1995, Land use, organochlorine compound concentrations, and trends in benthic-invertebrate communities in selected stream basins in Chester County, Pennsylvania: U.S. Geological Survey Water-Resources Investigations Report 94-4064, 78 p.

Heisig. P.M., 2000, Effects of residential and agricultural land uses on the chemical quality of base flow of small streams in the Croton Watershed, southeastern New York: U.S. Geological Survey Water-Resources Investigations Report 99-4173, $15 \mathrm{p}$. 
Hem, J.D., 1985, Study and interpretation of the chemical characteristics of natural water ( $3 d$ ed.): U.S. Geological Survey Water-Supply Paper 2254, 263 p.

Hilsenhoff, W.L., 1987, An improved biotic index of organic stream pollution: The Great Lakes Entomologist, v. 20, no.1, p. 31-39

Hirsch, R.M., Slack, J.R., and Smith, R.A., 1982, Techniques of trend analysis for monthly water-quality data: Water Resources Research, v. 18, no. 1, p. 107-121.

Lenat, D.R., and Crawford, J.K., 1994, Effects of land use on water quality and aquatic biota of three North Carolina Piedmont streams: Hydrobiologia, v. 294, no.3, p. 185-199.

Lenat, D.R., and Penrose, D.L., 1996, History of the EPT taxa richness metric: Bulletin of the North American Benthological Society, v. 13, no. 2, p. 305-307.

Lenz, B.N., and Miller M.A., 1996, Comparison of aquatic macroinvertebrate samples collected using different field methods: U.S. Geological Survey Fact Sheet FS-216-96, $4 \mathrm{p}$.

Lium, B.W., 1976, Limnological data for the major streams in Chester County, Pennsylvania: U.S. Geological Survey Open-File Report (unnumbered), 219 p.

Lium, B.W., 1977, Limnological studies of the major streams in Chester County, Pennsylvania: U.S. Geological Survey Open-File Report 77-462, 37 p.

Merritt, R.W., and Cummins, K.W., eds., 1996, An introduction to the aquatic insects of North America (3d ed.): Dubuque, Iowa, Kendall Hunt Publishing Company, 862 p.

Moore, C.R., 1987, Determination of benthic-invertebrate indices and water-quality trends of selected streams in Chester County, Pennsylvania, 1969-80: U.S. Geological Survey Water-Resources Investigations Report 85-4177, $62 \mathrm{p}$.

Moore, C.R., 1989, Physical, chemical, and biological data for selected streams in Chester County, Pennsylvania, 1969-80: U.S. Geological Survey Open-File Report 85-686, 289 p.

Mueller, D.K., Hamilton, P.A., Helsel, D.R., Hitt, K.J., and Ruddy, B.C., 1995, Nutrients in ground water and surface water of the United States-An analysis of data through 1992: U.S. Geological Survey Water-Resources Investigations Report 95-4031, 74 p.

Mullaney, J.R., Lorenz, D.L., Arntson, A.D., 2009, Chloride in groundwater and surface water in areas underlain by the glacial aquifer system, northern United States: U.S. Geological Survey Scientific Investigations Report 2009-5086, $41 \mathrm{p}$.

National Oceanic and Atmospheric Administration, 2005, Climactic data, annual summary, Pennsylvania, 2005: National Climatic Data Center, v. 110, no. 13.
Paul, M.J., and Meyer, J.L., 2001, Streams in the urban landscape: Annual Review of Ecology and Systematics, v. 32, p. 333-365.

Paul, M.J., and Zheng, L., 2007, Development of nutrient endpoints for the Northern Piedmont Ecoregion of Pennsylvania: TMDL application: Prepared for the United States Environmental Protection Agency Region 3, Philadelphia Pa. by Tetra Tech, Inc. Owings Mills, Md., 38 p.

Peckarsky, B.L., Fraissinet, P.R., Penton, M.A., and Conklin, D.J., Jr., 1990, Freshwater macroinvertebrates of Northeastern North America: Ithaca, N.Y., Cornell University Press, $442 \mathrm{p}$.

Rantz, S.E., and others, 1982, Measurement and computation of streamflow: Volume 1: Measurement of stage and discharge. Volume 2: Computation of discharge: U.S. Geological Survey Water-Supply Paper 2175, 631 p.

Reif, A.G., 1999, Physical, chemical, and biological data for selected streams in Chester County, Pennsylvania, 1981-94: U.S. Geological Survey Open-File Report 99-216, 607 p.

Reif, A.G., 2000, Physical, chemical, and biological data for selected streams in Chester County, Pennsylvania, 1995-97: U.S. Geological Survey Open-File Report 00-238, 146 p.

Reif, A.G., 2002, Assessment of stream conditions and trends in biological and water-chemistry data from selected streams in Chester County, Pennsylvania, 1981-1997: U.S. Geological Survey Water-Resources Investigations Report 02-4242, $77 \mathrm{p}$.

Reif, A.G., 2003, Assessment of water chemistry, habitat, and benthic macroinvertebrates at selected stream-quality monitoring sites in Chester County, Pennsylvania, 19982000: U.S. Geological Survey Open-File Report 03-499, 84 p.

Rounds, S.A., 2006, Alkalinity and acid neutralizing capacity (ver. 3.0): U.S. Geological Survey Techniques of WaterResources Investigations, book 9, chap. A6., section 6.6, July, accessed February 25, 2011, at http://pubs.water.usgs. gov/twri9A6/.

Senior, L.A., Sloto, R.A., and Reif, A.G., 1994, Hydrogeology and water quality of the West Valley Creek Basin, Chester County, Pennsylvania: U.S. Geological Survey WaterResources Investigations Report 94-4137, 160 p.

Senior, L.A., and Cinotto, P.J., 2007, Effect of on-site wastewater disposal on quality of ground water and base flowA pilot study in Chester County, southeastern Pennsylvania, 2005: U.S. Geological Survey Open-File Report 2007$1253,50 \mathrm{p}$.

Senior, L.A., and Sloto, R.A., 2010, Groundwater-quality monitoring program in Chester County, Pennsylvania, 1980-2008: U.S. Geological Survey Water-Resources Investigations Report 2010-5087, 83 p. 
Shannon, C.E., and Weaver, W., 1949, The mathematical theory of communication: Urbana, IL., University Illinois Press, $117 \mathrm{p}$.

Sloto, R.A., 1987, Effect of urbanization on the water resources of eastern Chester County, Pennsylvania: U.S. Geological Survey Water-Resources Investigations Report 87-4098, $131 \mathrm{p}$.

Smith, D.G., 2001, Pennack's freshwater invertebrates of the United States (4th ed.): New York, John Wiley and Sons, $638 \mathrm{p}$.

Stewart, K.W., and Stark, B.P., 2002, Nymphs of North American stonefly genera (2d ed.): Columbus, Ohio, The Caddis Press, $510 \mathrm{p}$.

Stoddard, J.L., Larsen, D.P., Hawkins, C.P., Johnson, R.K., and Norris, R.H., 2006, Setting expectations for the ecological condition of streams: the concept of reference condition: Ecological Applications v. 16, no.4, p. 1267-1276.

Thomas, J.C., Lutz, M.A., and others, 2007, Water-quality characteristics for selected sites within the Milwaukee Metropolitan Sewerage District planning area, Wisconsin, February 2004-September 2005: U.S. Geological Survey Scientific Investigations Report 2007-5084, 187 p.

Thorp, J.H., and Covich, A.P., 2001, Ecology and classification of North American freshwater invertebrates ( $2 \mathrm{~d}$ ed.): San Diego, Calif., Academic Press, 1,056 p.

U.S. Census Bureau, 2010, Census data accessed April 14, 2011, at http://www.2010.census.gov.

U.S. Environmental Protection Agency, 1986a, Ambient water quality criteria for dissolved oxygen: Washington, D.C., U.S. Environmental Protection Agency, EPA Number 440586003, $62 \mathrm{p}$.

U.S. Environmental Protection Agency, 1986b, Quality criteria for water, 1986: Washington, D.C., U.S. Environmental Protection Agency, EPA 440/5-86-001, 256 p.

U.S. Environmental Protection Agency, 1992, Drinking water regulations, U.S. Code of Federal regulations, Title 40, Part 141.61, Part 141.62 and Part 143.30, revised December, 1992: Washington, D.C., U.S. Environmental Protection Agency, Office of Water, $12 \mathrm{p}$.

U.S. Environmental Protection Agency, 1994, Water quality standards handbook (2nd ed.): Washington, D.C., U.S. Environmental Protection Agency, EPA 823-B-94-001A, $8 \mathrm{p}$.

U.S. Geological Survey, 1999, The quality of our nation's waters-nutrients and pesticides: U.S. Geological Survey Circular 1225, $82 \mathrm{p}$.
U.S. Geological Survey, 2002-2010, Water-resources data for Pennsylvania water year 2002-2010: U.S. Geological Survey Water-Data Report WRD-US-2002-2010, accessed March 20, 2011, at http;//pa.water.usgs.gov/infodata/surfacewater/annual_rpt.

U.S. Geological Survey, 2006, Collection of water samples (ver. 2.0): U.S. Geological Survey Techniques of WaterResources Investigations, book 9, chap. A4, accessed February 25, 2011, at http://pubs.water.usgs.gov/twri9A4/.

U.S. Geological Survey, 2009, Pennsylvania StreamStats, accessed March 22, 2011, at http://water.usgs.gov/osw/ streamstats/pennsylvania.html.

Vogel, K.L., and Reif, A.G., 1993, Geohydrology and simulation of ground-water flow in the Red Clay Creek Basin, Chester County, Pennsylvania, and New Castle County, Delaware: U.S. Geological Survey Water-Resources Investigations Report 93-4055, $111 \mathrm{p}$.

Waters, T.F., 1995, Sediment in streams: sources, biological effects and control: Bethesda, Md., American Fisheries Society, American Fisheries Society Monograph 7, 251 p.

Westfall, M.J., Jr., and May, M.L., 1996, Damselflies of North America: Gainesville, Fla., Scientific Publishers, Inc., $650 \mathrm{p}$.

Westfall, M.J., Jr., and May, M.L., 2000, Dragonflies of North America: Gainesville, Fla., Scientific Publishers, Inc., $940 \mathrm{p}$.

Wiggins, G.B., 1996, Larvae of the North American caddisfly genera (Trichoptera) (2d ed.): Toronto, University of Toronto Press, 457 p.

Wilde, F.D., ed., chapter sections variously dated, Field measurements: U.S. Geological Survey Techniques of Water-Resources Investigations, book 9, chap. A6, accessed February 25, 2011, at http://pubs.water.usgs.gov/twri9A6/.

Wilde, R.D., Radtke, D.B., Gibs, J., and Iwatsubo, R.T., 1998, National field manual for the collection of waterquality data: U.S. Geological Survey Techniques of WaterResources Investigations, book 9, variously paged.

Wilde, F.D., ed., 2004, Cleaning of equipment for water sampling (ver. 2.0):U.S. Geological Survey Techniques of Water-Resources Investigations, book 9, chap. A3, accessed February 25, 2011, at http://pubs.water.usgs.gov/twri9A3/.

Wilde, F.D., Radtke, D.B., Gibs, Jacob, and Iwatsubo, R.T., eds., 2004, Processing of water samples (ver. 2.1): U.S. Geological Survey Techniques of Water-Resources Investigations, book 9, chap. A5, accessed February 25, 2011, at http://pubs.water.usgs.gov/twri9A5/. 


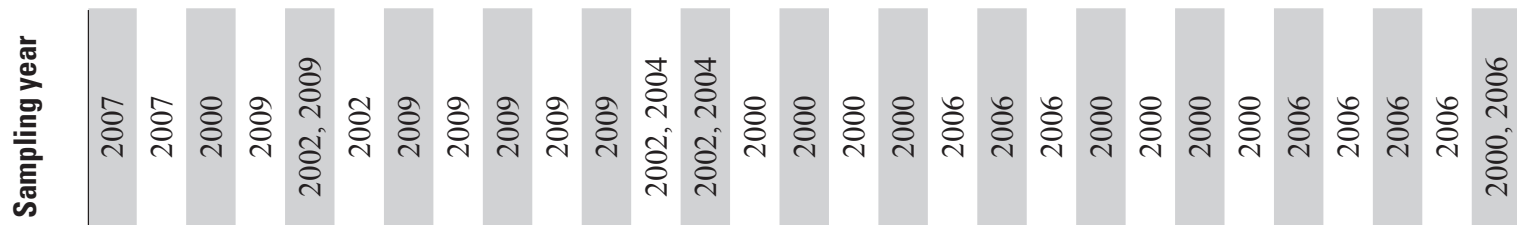

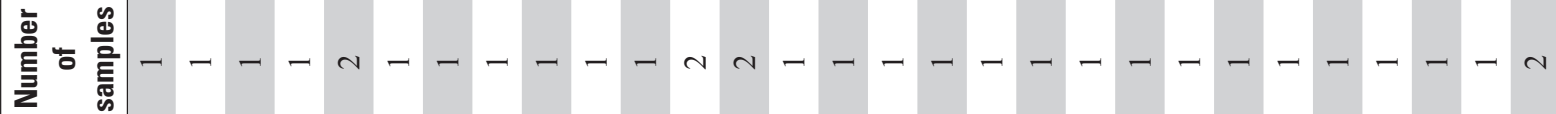

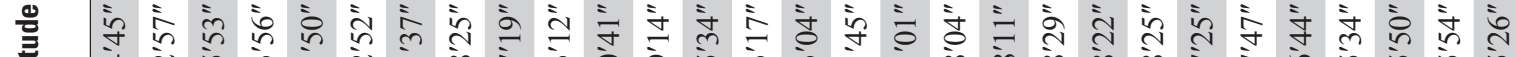

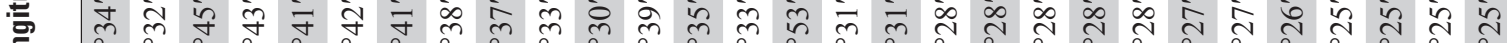

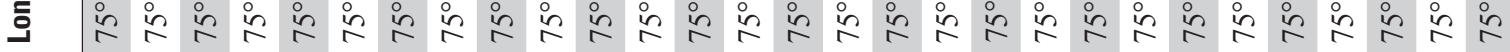

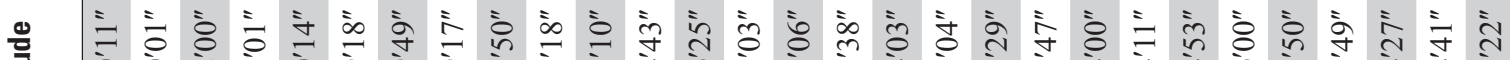

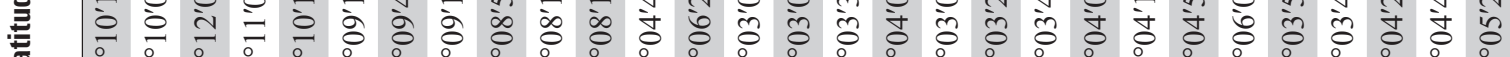
J

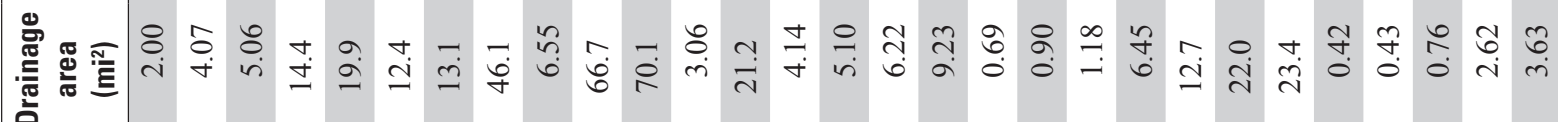

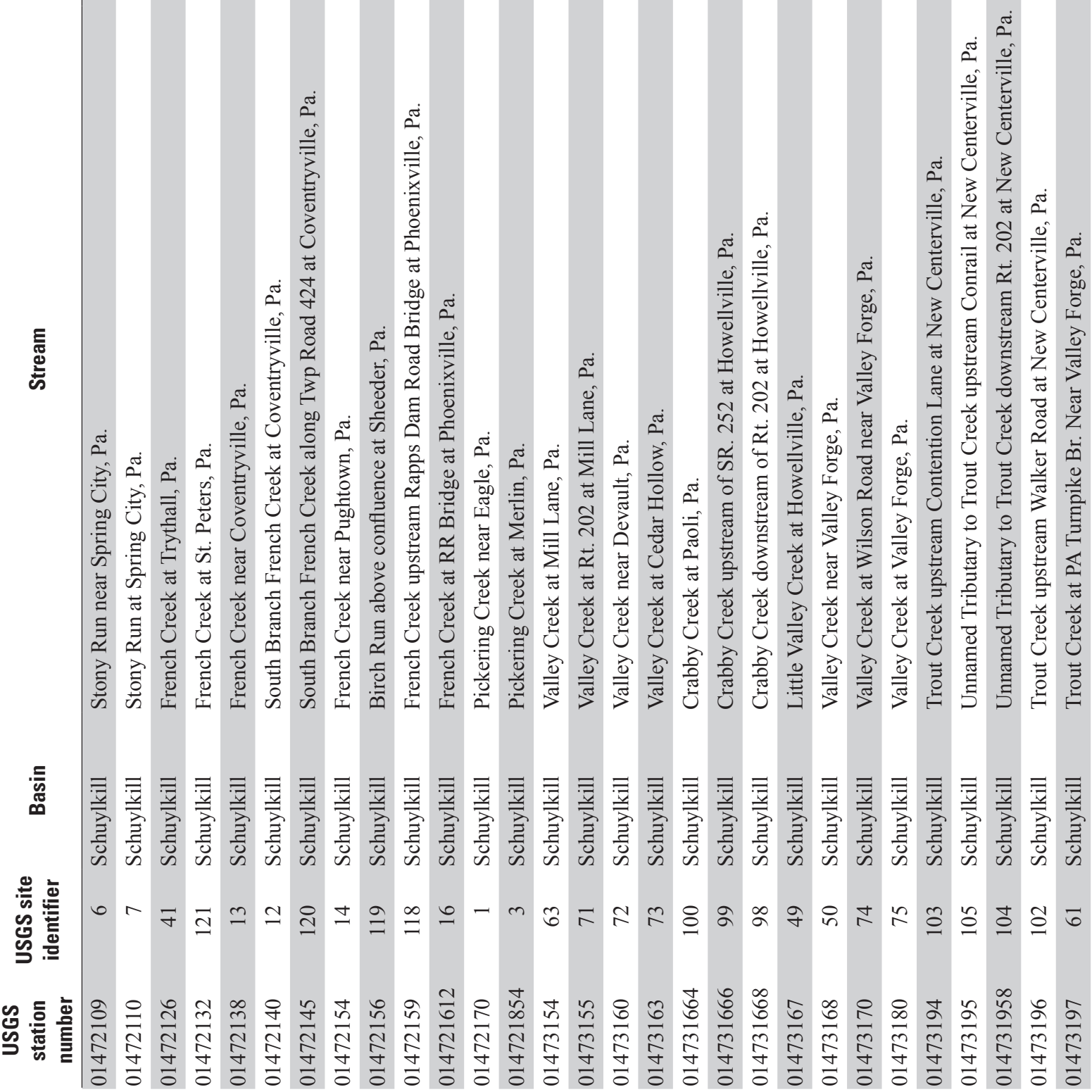



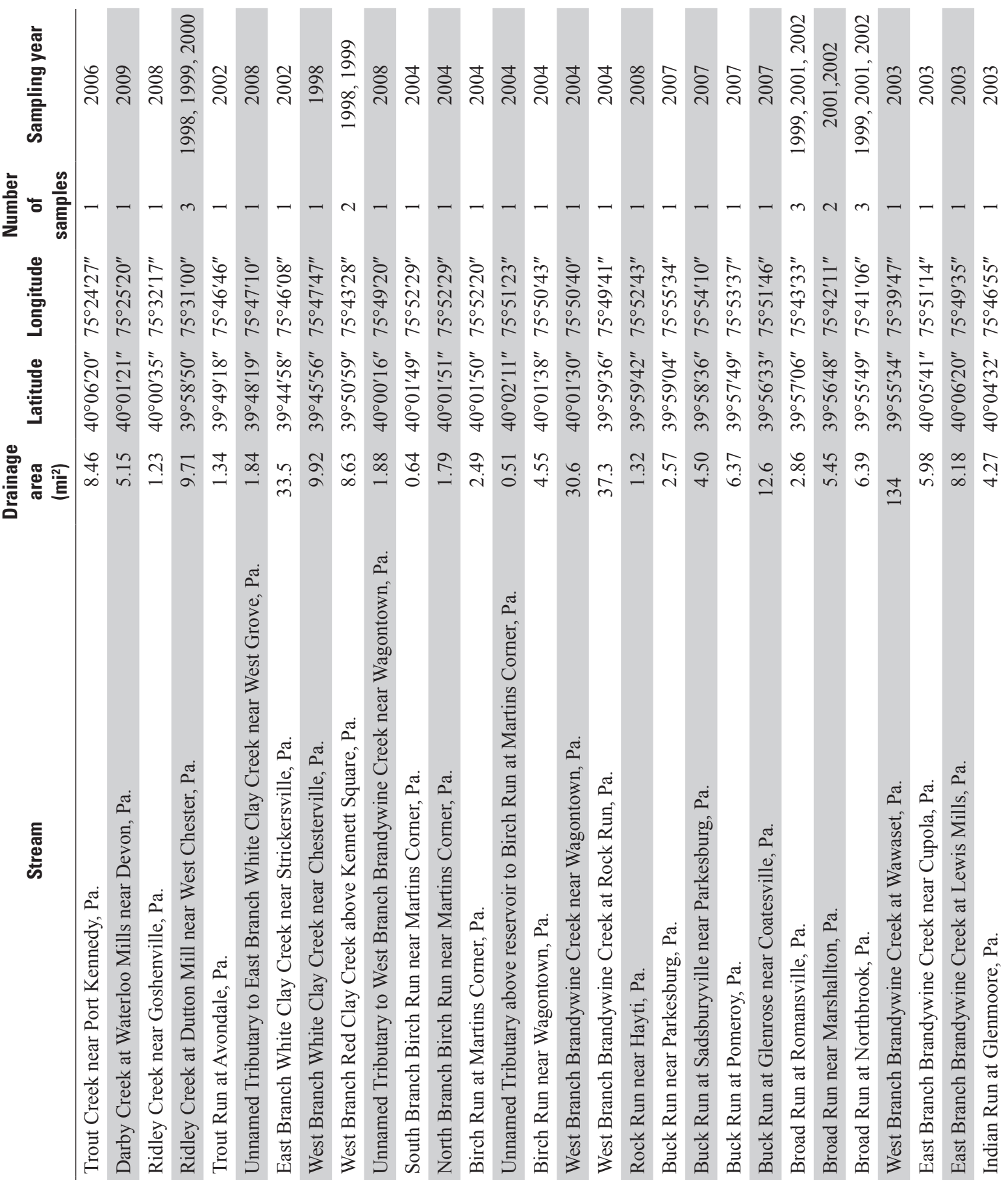

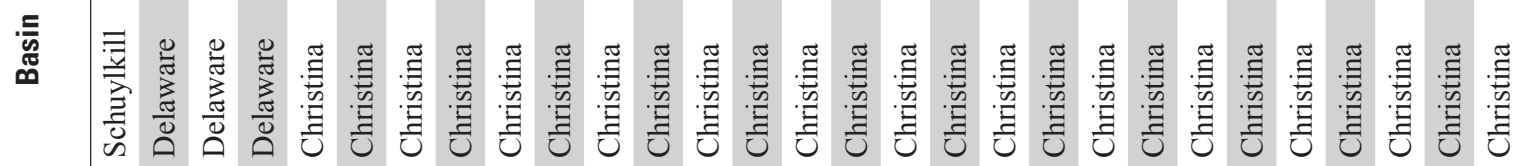
岁衰离

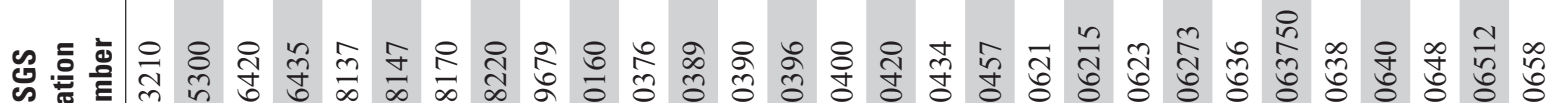

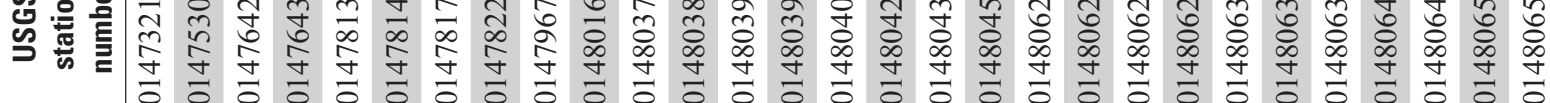




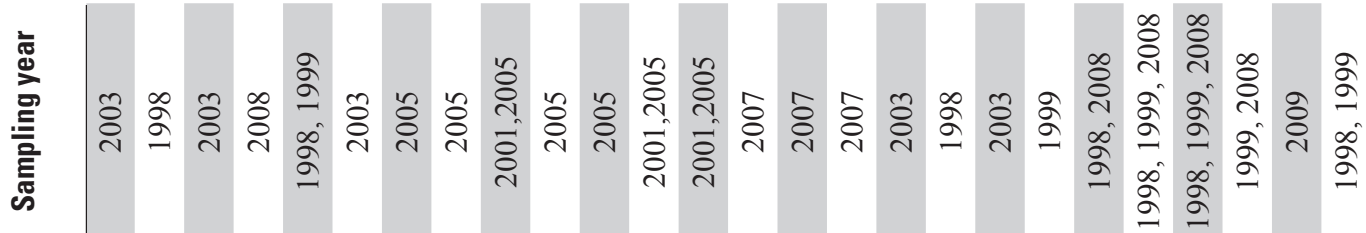

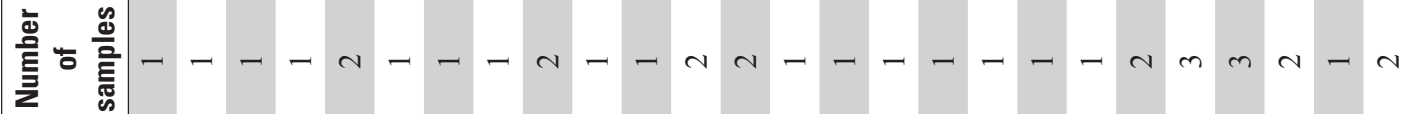

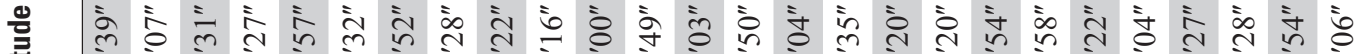

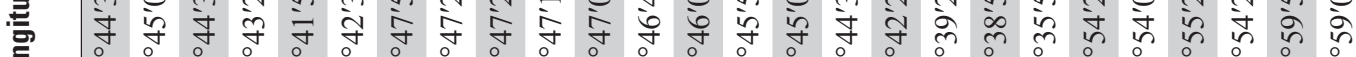

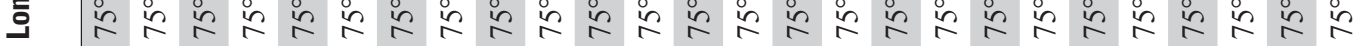

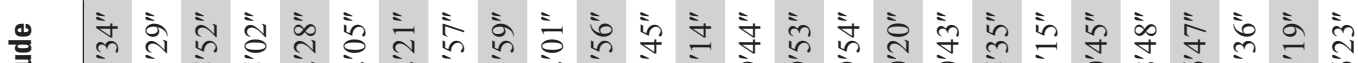
灵

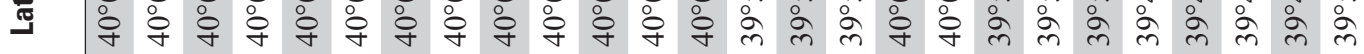

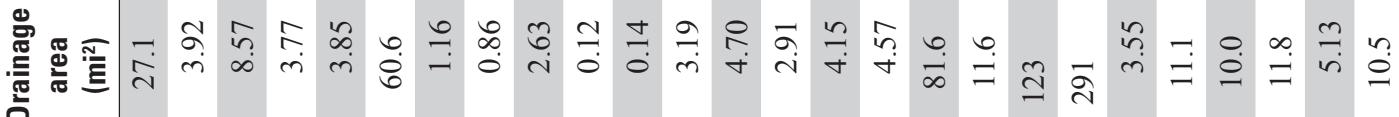

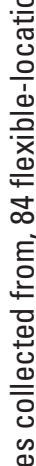

$\frac{\mathscr{o}}{2}$

㝕焉

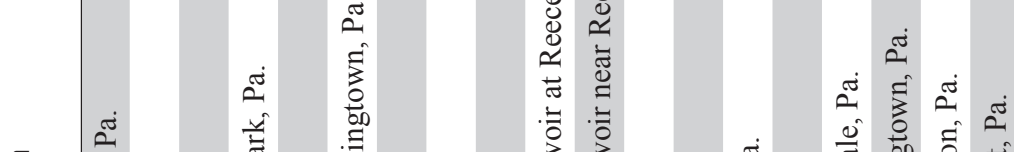

$\cos ^{\circ}$

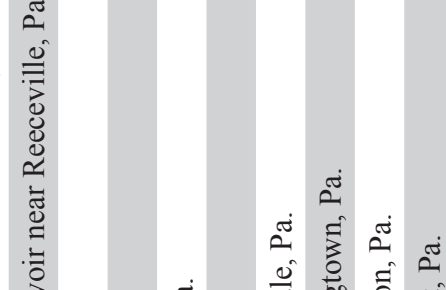

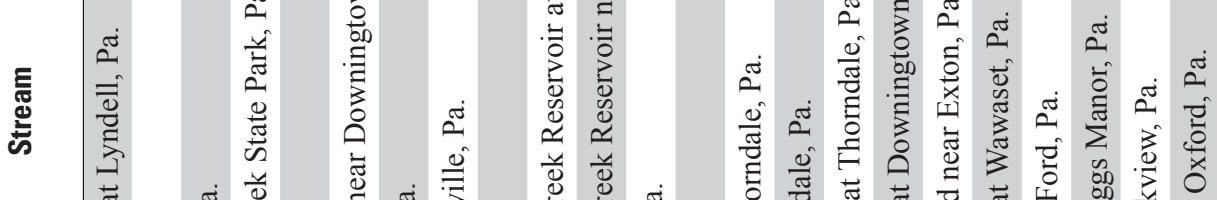

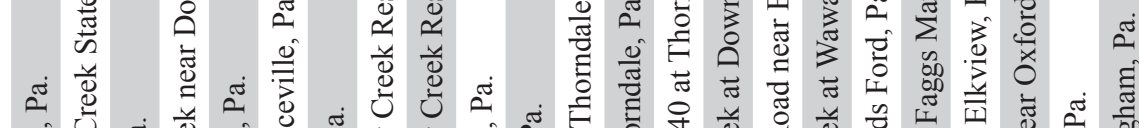

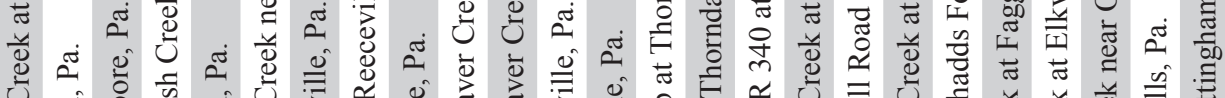

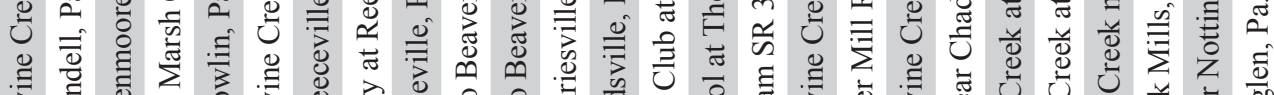

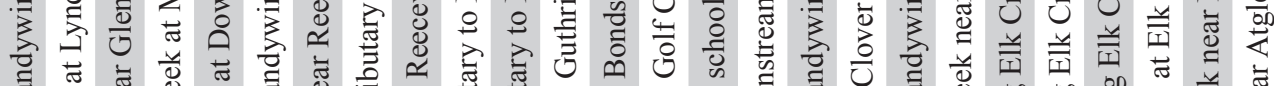

ప ज

صी

元 ต 总 寻芯

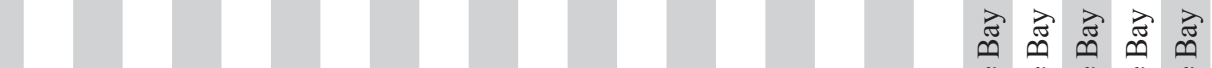

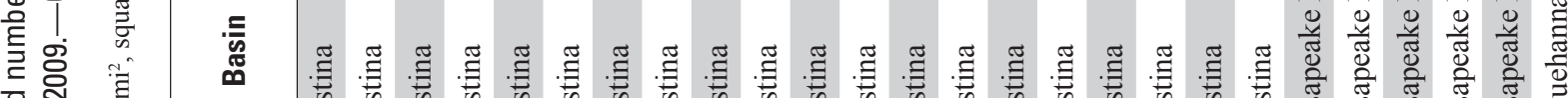

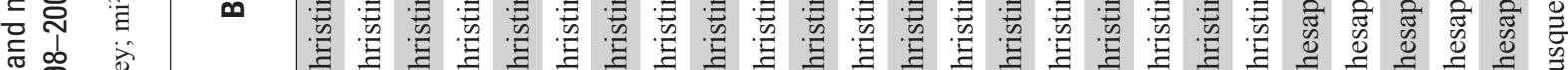

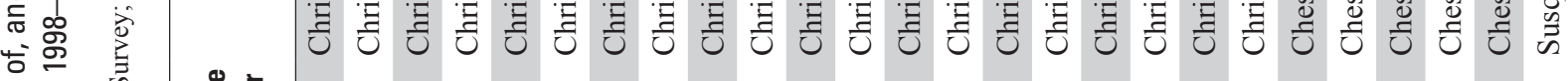

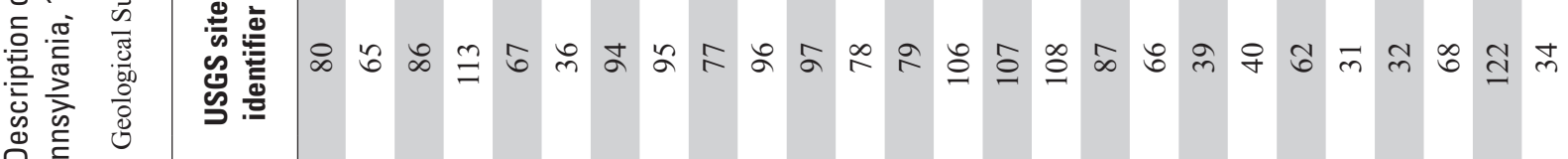

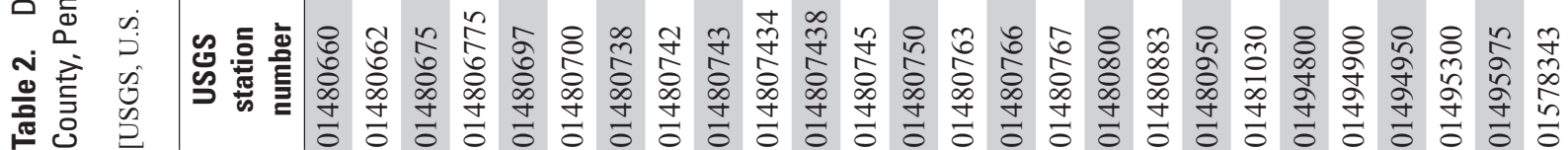



Prepared by the West Trenton Publishing Service Center

For additional information write to:

Director, Pennsylvania Water Science Center

U.S. Geological Survey

215 Limekiln Road

New Cumberland, PA 17070-2424

http://pa.water.usgs.gov/ 
